UNIVERSIDADE DE SÃO PAULO INSTITUTO DE FÍSICA DE SÃO CARLOS

EMERY CLEITON CABRAL CORREIA LINS

\title{
ESPECTROSCOPIA DA FLUORESCÊNCIA NA CITRICULTURA
}



EMERY CLEITON CABRAL CORREIA LINS

\section{Espectroscopia da fluorescência na citricultura}

Tese apresentada ao Programa de PósGraduação em Física do Instituto de Física de São Carlos da Universidade de São Paulo para obtenção do título de Doutor em Ciências.

Área de concentração: Física Aplicada.

Orientador: Prof. Dr. Luis G. Marcassa.

São Carlos - SP 


\begin{abstract}
AUTORIZO A REPRODUÇÃO E DIVULGAÇÃO TOTAL OU PARCIAL DESTE TRABALHO, POR QUALQUER MEIO CONVENCIONAL OU ELETRÔNICO, PARA FINS DE ESTUDO E PESQUISA, DESDE QUE CITADA A FONTE.
\end{abstract}

Ficha Catalográfica elaborada pelo Serviço de Biblioteca e Informação

Lins, Emery Cleiton Cabral Correia.

Espectroscopia da fluorescência na citricultura / Emery Cleiton Cabral Correira Lins; orientador Luis G. Marcassa.- edição revisada - São Carlos, 2009.

$116 \mathrm{p}$.

Tese (Doutorado em Ciências - Área de concentração Física Aplicada - Instituto de Física de São Carlos da Universidade de São Paulo).

1. Cancro cítrico. 2. Diagnóstico óptico. 3. Fluorescência da clorofila. 4. Espectroscopia da fluorescência. 5. Imagens da fluorescência. I. Título. 
Este exemplar foi revisado e alterado em relação a versão original, sob a exclusiva responsabilidade do autor.

São Carlos, _ _ de __ de 2009. 



\section{AGRADECIMENTOS}

A Deus pela dedicação à minha pessoa, acalentando-me nos momentos de angústia e me revelando caminhos para que eu pudesse tomar minhas decisões.

A minha esposa Juliana e ao meu filho Ian, que de forma incondicional entenderam e aceitaram meus momentos de dificuldade no decorrer do trabalho. Seu amor por mim me revigorava e motivava em seguir adiante. Sem eles do meu lado o fardo seria mais pesado.

Ao meu orientador L. G. Marcassa, pelo acompanhamento e suporte durante o trabalho e principalmente pela sinceridade com as minhas expectativas para o futuro. Nossas conversas me revelaram que para alguns poucos orientar ainda é dar orientação.

Aos meus pais, que mesmo à distância sempre me incentivaram a continuar o trabalho e desenvolver ainda mais. Seu conforto foi de fundamental importância para mim.

Aos meus demais familiares, principalmente meus irmãos e tias. Seu carinho por mim sempre me deixou orgulho; e a forma como eles respeitam meu trabalho me deixa muito satisfeito.

Ao pesquisador José Belasque Jr., que representava o FUNDECITRUS durante nossa jornada. Ao seu lado aprendi bastante sobre a citricultura, além de outros temas de conhecimento geral. Nossas viagens ao campo para medições experimentais seriam menos interessantes sem a sua presença.

A todos os colegas e funcionários do FUNDECITRUS que de alguma forma contribuíram para o nosso trabalho. Agradeça também a Maria Cândida C. Gasparoto, por compartilhar sue tempo e conhecimento para que os experimentos tivessem sucesso.

Ao aluno Caio Wetterich que me ajudou em alguns experimentos que resultaram essa tese.

Aos meus eternos amigos que convivo no Grupo de Ótica do IFSC: Denis Jacomassi, José Dirceu e Lilian Tan Moriyama (o quadrado mágico sempre será eterno); Fernando Florez e Augusto Figueiredo (Os Predadores); Clóvis Grecco e Gustavo Sabino (pelas peladinhas de Futcampo); Mardoqueu da Costa (grande companheiro); Sebastião Pratavieira, Jeison Tribiolli e Paula Amaral; Ruy Matosinho, Ewerton (o boto), Gustavo (o gaúcho), Raquel Rêgo; Natália Inada e todos os demais da Biofotônica; Orlando, Matão, João Marcelo, Leila, Igor, Alexandre, Eliseu e todos os demais da ATÔMICA, do LAT e do LIEPO; Camila Fávero e as colegas de Araraquara. Agradeço imensamente ter compartilhado ótimos momentos com vocês.

Ao Professores do IFSC que contribuíram para a realização do meu trabalho. Em especial Vanderlei Bagnato e Cristina Kurachi; pela sinceridade e apoio.

Ao CNPq pelo meu suporte financeiro na forma de bolsa e taxa de bancada. Em especial a taxa de bancada me ajudou bastante na divulgação do meu trabalho.

A FAPESP pelo suporte financeiro através de projetos. Com esse apoio foi possível desenvolver nossos sistemas. 


\section{RESUMO}

LINS, E. C. C. C., Espectroscopia da fluorescência na citricultura. 2009. Tese (Doutorado) - Instituto de Física de São Carlos, Universidade de São Paulo, São Carlos, 2009.

O cancro cítrico é uma das doenças mais temidas da citricultura devido ao seu poder de proliferação nas fazendas, aos danos causados às plantas e aos frutos e à forma de combate adotada pelos órgãos responsáveis através da erradicação das plantas contaminadas e de outras em sua vizinhança. No Brasil, um dos principais motivos que minimiza a eficiência da erradicação do cancro cítrico é a confirmação do diagnóstico, que necessita ser realizada em alguns laboratórios credenciados. A análise de muitas amostras em conjunto com o tempo gasto com o transporte aumenta a chance de proliferação da doença no campo. Neste trabalho aplicamos técnicas de espectroscopia da fluorescência em folhas de culturas cítricas na intenção de propor um método de diagnóstico do cancro cítrico a ser realizado na fazenda e com resposta em tempo real. As amostras experimentais são folhas de variedades cítricas sadias e contaminadas com cancro ou outras doenças. Iniciamos o trabalho aplicando espectroscopia da fluorescência no laboratório. Os resultados provaram a viabilidade do método, mas revelou uma enorme sobreposição de dados ao tentar discriminar o cancro de outra doença. Análises complementares nos revelaram que os experimentos deveriam ser feitos no campo, identificando plantas contaminadas e tomando a fluorescência de folhas sadias como referência. A espectroscopia da fluorescência no campo foi feita com um espectrômetro portátil. O resultado nos possibilitou propor critérios de discriminação do cancro baseado em figuras de mérito. $\mathrm{O}$ melhor critério apresentou $82 \%$ de acertos, com $93 \%$ de sensibilidade e $63 \%$ de especificidade. Concluímos que os valores poderiam ser melhores se a espectroscopia fosse realizada com imagens, pois as variações do espectro ocorrem devido ao posicionamento da fibra na lesão do cancro. Passamos a estudar a espectroscopia das imagens da fluorescência com um sistema baseado em um espectrógrafo. Os resultados provaram a viabilidade do estudo e revelaram particularidades espaciais e espectrais das doenças. Infelizmente essa instrumentação só pode ser usada no laboratório, por isso optamos por desenvolver outro sistema mais simples e robusto, a base de uma roda de filtros com filtros passa-banda. Os resultados revelaram novas particularidades espaciais e espectrais das amostras, porém nos revelou a necessidade de um processamento de imagem para obter análises quantitativas. O sistema de imagens com filtro ainda foi usado em outro experimento complementar onde as imagens forneceram resultados quantitativos, provando a funcionalidade da técnica.

Palavras-chave: Cancro cítrico, Diagnóstico óptico, Fluorescência da clorofila, Espectroscopia da fluorescência, Imagens da fluorescência. 


\begin{abstract}
LINS, E. C. C. C., Fluorescence spectroscopy in citrus. 2009. Thesis (Doctoral) - Instituto de Física de São Carlos, Universidade de São Paulo, São Carlos, 2009.

Citrus canker is one of the most feared diseases of citrus due to its dissemination in the farms, the damage caused to plants and fruits and the combat strategy adopted by national government through the eradication of infected plants and others in your neighborhood. In Brazil, one of the main reasons that minimizes the effectiveness of citrus canker`s eradication is the confirmation of the diagnosis by specialized laboratories. The time spent in transport and analyses of many samples increases the chance of canker spreading in the field. In our work we apply spectroscopic techniques of fluorescence in leaves of citrus crops with the aim to propose a method for diagnosis of citrus canker to be held on the farm and with real-time response. The experimental samples are leaves of healthy citrus varieties and contaminated with canker or other diseases. We began the work by applying fluorescence spectroscopy in the laboratory. The results proved the feasibility of the method, but showed a huge overlap of data in trying to discriminate canker from other diseases. Further analysis revealed that those experiments should be done in the field, focusing to identify infected plants and taking the fluorescence of healthy leaves as a reference. Fluorescence spectroscopy in the field was made with a portable spectrometer. The result allowed us to propose some criteria for canker discrimination based on figures of merit. The best criteria presents $82 \%$ correct tests, with $93 \%$ sensitivity and $63 \%$ specificity. We conclude that these values could be better if the spectroscopy was performed with images, because the variations of the spectrum are due to the positioning of the fiber over the canker lesion. We start the studies of spectroscopy of fluorescence images with a system based on a spectrograph. The results proved its feasibility and revealed spatial and spectral particular features of the diseases. Unfortunately, this instrumentation can only be used in the laboratory, so we decided to develop another system more simple and robust. The new system is based on a filter wheel with band-pass filters. The results revealed new spatial and spectral characteristics of the samples, but revealed the need for an image processing for quantitative analysis. This imaging system was still used in another supplementary experiment where the images have provided quantitative results, proving the functionality of the technique.
\end{abstract}

Keywords: Citrus canker, Optical diagnostic, Chlorophyll Fluorescence, Fluorescence spectroscopy, Fluorescence imaging. 


\section{LISTA DE FIGURAS}

Figura 1.1. Gráfico da participação percentual do Brasil em alguns mercados de produtos do agronegócio em 2003 e em 2007

Figura 1.2. Tabela com o montante de divisas financeiras geradas pela exportação alguns produtos do agronegócio em 2003 e em 2007.

Figura 2.1. $\quad$ Espectros de absorção molar (linha pontilhada) e da emissão da fluorescência (linha cheia) de alguns dos principais pigmentos contidos nas folhas.

Figura 2.2. $\quad$ Espectro de absorção dos fotossistemas FSI e FSII responsáveis pela ocorrência da fotossíntese.

Figura 2.3. Espectro de absorção de um extrato alcoólico dos pigmentos contidos nas folhas e espectros da fluorescência induzida por UV emitida por folhas de ervilhas (Pisum sativum L.) e por folhas de beterraba (Beta vulgaris L.)

Figura 2.4. Espectro da fluorescência induzida por LASER $(532 \mathrm{~nm})$ emitida por uma folha sadia de laranjeira. Destaque para os dois picos de emissão da fluorescência, em 690 nm e 740 nm. 31

Figura 2.5. Cubo de dados espectrais que revela uma propriedade óptica de uma amostra experimental com resolução espectral e espacial.

Figura 2.6. Exemplo de composição de imagens espectrais com varredura espacial..

Figura 3.1. Esquema de funcionamento do espectrômetro destacando o caminho óptico da luz de excitação, da reflexão e da fluorescência, além dos principais componentes: Laser de excitação, cabo de fibras ópticas em Y, monocromador e computador.

Figura 3.2. Imagem digital do espectrômetro de fluorescência e um espectro capturado

Figura 3.3. Esquema e imagem digital do SIE mostrando as partes que compõem o sistema e a localização de cada parte.

Figura 3.4. Exemplo de imagem formada no espectrógrafo, que revela a ordem zero e a primeira ordem de difração e outros parâmetros da calibração do SIE.

Figura 3.5. Calibração espacial do SIE. Variação do campo de visão e da largura em função da distância entre o sistema de lentes e a amostra.

Figura 3.6. Resolução espacial do SIE em função da distância entre o sistema de lentes e a amostra......

Figura 3.7. Gráfico da calibração espectral do SIE

Figura 3.8. Exemplo de imagens espectrais capturadas pelo SIE utilizando $25 \mathrm{~mW} / \mathrm{cm}^{2}$ de luz azul em $470 \mathrm{~nm}$ para iluminação. (a) Imagem digital de uma folha com CVC apresentando os sintomas visuais da doença. (b) Imagem espectral da fluorescência emitida em $690 \mathrm{~nm}$ revelando a informação espectral e espacial. (c) O mesmo tipo de informação presente em (b), sendo $740 \mathrm{~nm}$ o comprimento de onda de emissão da fluorescência

Figura 3.9. Esquema da montagem do SIF e imagem digital do sistema pronto para uso.....

Figura 3.10. Exemplo de imagens espectrais capturadas pelo SIF utilizando $25 \mathrm{~mW} / \mathrm{cm}^{2}$ de luz azul em $470 \mathrm{~nm}$ para iluminação. (a) Imagem digital de uma folha com cancro cítrico apresentando os sintomas visuais da doença. (b) e (c) Imagens espectrais da fluorescência emitida pela amostra em $690 \mathrm{~nm}$ e $740 \mathrm{~nm}$, respectivamente, revelando a informação espectral e espacial da região de interesse selecionada. 
Figura 4.1. Fotografia digital de duas lesões de cancro cítrico em uma folha de laranjeira, mostrando a região necrótica e a região além da necrose que ainda apresenta sintoma da infecção....... 58

Figura 4.2. Exemplo do ruído existente na medida da fluorescência de uma folha cítrica devido às flutuações na detecção do sensor do espectrômetro.

Figura 4.3. Resultados dos experimentos da espectroscopia da fluorescência em laboratório.

Distribuição dos valores de $\mathrm{FM}_{2}$ em função dos valores de $\mathrm{FM}_{1}$ para comparar o comportamento de amostras sadias e contaminadas por cancro cítrico e CVC

Figura 4.4. Distribuição dos valores das figuras de mérito $\mathrm{FM}_{1}$ e $\mathrm{FM}_{2}$ em função do tempo de colheita das folhas

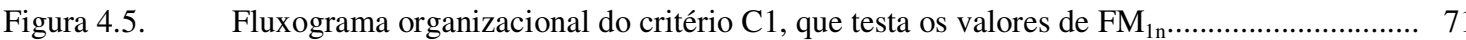

Figura 4.6. Fluxograma organizacional do critério C2. Neste critério $\mathrm{FM}_{1 \mathrm{n}}$ e FM $\mathrm{FM}_{3 \mathrm{n}}$ são testados........... 72

Figura 4.7. Fluxograma organizacional do critério C3. Neste critério $\mathrm{FM}_{1 \mathrm{n}}$ e $\mathrm{C}(0)_{\mathrm{n}}$ são testados............. 72

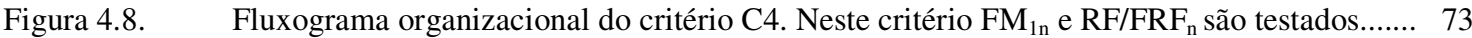

Figura 4.9. Fluxograma organizacional do critério C5. Este critério testa os valores de $\mathrm{FM}_{1 \mathrm{n}}, \mathrm{FM}_{3 \mathrm{n}} \mathrm{e}$ $\mathrm{RF} / \mathrm{FRF}$

Figura 5.1. Teste comparativo da intensidade de fluorescência detectada pelo SIE quando luz azul ou violeta é utilizada para excitação. Para formar as imagens o tempo de exposição foi 20 segundos e a intensidade de iluminação $25 \mathrm{~mW} / \mathrm{cm}^{2}$

Figura 5.2. Imagem digital e imagens espectrais (690 nm, $740 \mathrm{~nm}$ e a RF/FRF) de uma amostra contaminada por cancro cítrico e uma por verrugose. Para essas imagens o SIE foi usado, com 20 segundos de exposição da CCD e intensidade de iluminação de $25 \mathrm{~mW} / \mathrm{cm}^{2}$.

Figura 5.3. Imagem digital e imagens espectrais $(690 \mathrm{~nm}, 740 \mathrm{~nm}$ e a RF/FRF) de uma amostra contaminada por CVC e uma por greening. Para essas imagens o SIE foi usado, com 20 segundos de exposição da CCD e intensidade de iluminação de $25 \mathrm{~mW} / \mathrm{cm}^{2}$.

Figura 5.4. Imagens espectrais da $\mathrm{RF} / \mathrm{FRF}_{\mathrm{n}}$ (normalizada pelos dados de folhas sadias) por uma amostra contaminada por cancro cítrico, uma com verrugose, uma com greening e uma com CVC. O SIE foi o sistema utilizado

Figura 5.5. Imagens espectrais da fluorescência emitida em $615 \mathrm{~nm}$ por uma amostra contaminada por cancro cítrico, uma com verrugose, uma com greening e uma com CVC. O SIE foi utilizado neste experimento com 20 segundos de exposição da CCD e intensidade de iluminação de $25 \mathrm{~mW} / \mathrm{cm}^{2}$.

Figura 5.6. Imagem digital e imagens espectrais $(570,610,690$ e $740 \mathrm{~nm})$ capturadas de uma folha de laranjeira contaminada com cancro cítrico. O sistema foi o SIF com 10 segundos de exposição da CCD, $10 \mathrm{~dB}$ de ganho e intensidade de iluminação de $25 \mathrm{~mW} / \mathrm{cm}^{2}$.....

Figura 5.7. Imagem digital e imagens espectrais $(570,610,690$ e $740 \mathrm{~nm})$ capturadas de uma folha de laranjeira contaminada com verrugose. O sistema foi o SIF com 10 segundos de exposição da CCD, $7 \mathrm{~dB}$ de ganho e intensidade de iluminação de $25 \mathrm{~mW} / \mathrm{cm}^{2}$

Figura 5.8. Imagens espectrais das razões $\mathrm{RF} / \mathrm{FRF}$ e $\mathrm{RF} / \mathrm{FRF}_{\mathrm{n}}$ das folhas de laranjeiras contaminada por cancro cítrico e por verrugose. Imagens capturadas usando o SIF..

Figura 5.9. Imagens espectrais da fluorescência emitida em 570, 610, 690 e $740 \mathrm{~nm}$, por amostras não-usuais encontradas no campo (fruto limão galego contaminado por cancro cítrico, fruto limão cravo contaminado por verrugose e um ramo de cidra contaminado por cancro cítrico). Imagens capturadas usando o SIF. 
Figura 5.10. Resultados publicados por E. Katz e co-autores sobre a emissão de etileno por folhas de laranja valência em função do tempo de colheita das folhas. As amostras experimentais foram folhas jovens e folhas maduras em ambiente aéreo e em ambiente com presença de etileno.

Figura 5.11. Imagens espectrais da razão RF/FRF mostrando a evolução da fluorescência emitida pela região de interesse em função do tempo de colheita da folha. Há 12 imagens, pois a figura (a) se refere ao dia 1 e a figura (1) se refere ao dia 12

Figura 5.12. Gráficos da evolução e da primeira derivada das razões RF/FRF e R1 (F570/F690) em função do tempo entre a colheita da folha e a medição da fluorescência. 


\section{LISTA DE TABELAS}

Tabela 3.1. Características ópticas dos filtros passa-banda utilizados no SIF

Tabela 4.1. Resultados da espectroscopia da fluorescência no campo. Valor médio (m), desvio padrão (dp) e número de amostras (n) de todas as figuras de mérito normalizadas (FM1n, FM2n, FM3n, FM4n, C(0)n e RF/FRFn) para cada uma das doenças: cancro cítrico, verrugose, greening e crc.

Tabela 4.2. Número de verdadeiros positivos (VP), verdadeiros negativos (VN), falsos positivos (FP) e falsos negativos (FN) de cada critério estudado para o diagnóstico do cancro cítrico com a espectroscopia da fluorescência no campo..

Tabela 4.3. Parâmetros estatísticos calculados a partir dos dados da Tabela 4.2: sensibilidade (S), especificidade (E), valor preditivo positivo (VPP), valor preditivo negativo (VPN), precisão $(\mathrm{P})$, acurácia $(\mathrm{A})$, razão de verossimilhança positiva (RVP) e razão de verossimilhança negativa $(\mathrm{RVN})$. 


\section{SUMÁRIO}

$\begin{array}{ll}\text { 1. INTRODUÇÃO } & 14\end{array}$

2. REVISÃO DA LITERATURA 21

2.1. Espectroscopia de refletância e fluorescência 21

2.1.1. Espectroscopia da refletância $\quad 21$

2.1.2. Espectroscopia da fluorescência 24

2.1.2.1. Formas de análise da fluorescência 30

2.2. Instrumentação

2.2.1. Refletância sem fibra 32

2.2.2. Refletância e fluorescência com fibra 32

2.2.3. Imagens espectrais da refletância e da fluorescência 34

2.2.3.1. Imagens com varredura espectral 36

2.2.3.2. Imagens com varredura espacial 36

2.2.4. Processamento das imagens espectrais 38

3. INSTRUMENTAÇÃO E MONTAGEM 40

3.1. Espectroscopia de fluorescência induzida por LASER

3.2. Espectroscopia de imagem de fluorescência $\mathbf{4 2}$

3.2.1. Sistema de imagens espectrais baseado em espectrógrafos 43

3.2.1.1. Componentes do SIE 43

3.2.1.2. Principio de funcionamento do SIE 45

3.2.1.3. Calibração do SIE

3.2.1.4. Composição da imagem espectral 49

3.2.2. Sistema de imagens espectrais baseado em filtros ópticos 51

3.2.2.1. Componentes do SIF 51

3.2.2.2. Aquisição das imagens espectrais do SIF 53

4. ESPECTROSCOPIA A FIBRA 56

4.1. Espectroscopia a fibra no laboratório do IFSC 56

4.1.1. Metodologia 56

4.1.2. Análise dos Espectros $\quad 58$

4.1.2.1. Pré-processamento dos espectros 58

4.1.2.2. Razões da fluorescência $\quad 60$

4.1.3. Resultados e discussões $\quad 61$

4.1.4. Influência do tempo de destacamento sobre a emissão da fluorescência pelas folhas 63

4.2. Espectroscopia a fibra no campo $\quad 65$

4.2.1. Nova metodologia $\quad 65$

$\begin{array}{lll}\text { 4.2.2. } & \text { Análise dos espectros } & 67\end{array}$ 
4.2.2.1. Outras razões da fluorescência

4.2.2.2. Autocorrelação do espectro da fluorescência 68

4.2.2.3. Parâmetros normalizados 199

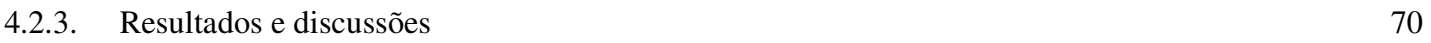

5. ESPECTROSCOPIA DAS IMAGENS DA FLUORESCÊNCIA 77

$\begin{array}{ll}\text { 5.1. } & \text { Experimentos com o sistema com o espectrógrafo }\end{array}$

5.1.1. Metodologia na coleta das imagens $\quad 77$

$\begin{array}{ll}\text { 5.1.1.1. Efeito da fonte de excitação } & 78\end{array}$

5.1.2. Metodologia no processamento das imagens 80

5.1.2.1. Análise das imagens espectrais $\quad 80$

5.1.3. Resultados 80

5.2. Experimentos com o sistema com uma roda de filtros $\quad \mathbf{8 6}$

5.2.1. Metodologia 86

5.2.2. Resultados $\quad 87$

5.3. Experimento quantitativo utilizando sistema com uma roda de filtros - correlação entre a fluorescência emitida e a taxa de produção de etileno pelas folhas cítricas

6. CONCLUSÕES $\quad 99$

$\begin{array}{lr}\text { REFERENNCIAS } & 102\end{array}$

$\begin{array}{lr}\text { APÊNDICE A } & 109\end{array}$

$\begin{array}{lr}\text { ANEXO A } & 114\end{array}$ 


\section{INTRODUÇÃO}

Tradicionalmente, o Brasil tem sido um dos grandes países exportadores de commodities agrícolas e insumos do agronegócio. Esses produtos são essenciais para o PIB nacional e destacam o Brasil como um dos países com maior poder de investimentos no agronegócio. Alguns fatores são favoráveis ao Brasil. Entre eles se destaca a quantidade de terra fértil ainda disponível para plantio, a evolução tecnológica das indústrias brasileiras, a disponibilidade hídrica do país e o aumento da demanda nacional e internacional dos produtos aqui produzidos.

A demanda internacional merece destaque particular. Uma vez que centros econômicos emergentes, como a China e a Índia, passaram a acumular mais riqueza e a demandar por mais produtos alimentícios, cresceu também o mercado de consumo dos produtos derivados da agricultura do Brasil.

Em um trabalho publicado em 2008 com o título "Produtos do agronegócio: exportações, importações mundiais e inserção brasileira", o Ministério da Agricultura, Pecuária e Abastecimento (MAPA) divulgou a participação do Brasil no mercado internacional de doze dos principais produtos do agronegócio Brasileiro no período entre 2003 e 2007 (15).

A Figura 1.1 apresenta um gráfico presente neste trabalho do MAPA que revela a participação do Brasil nos tais doze mercados, destacando que em cinco deles (carne de peru industrializada, suco de laranja, açúcar bruto e refinado, álcool etílico e carne bovina industrializada) o Brasil tem participação acima de 50\%. Na mesma publicação há uma tabela com o faturamento que o Brasil obteve com a exportação de 23 produtos do agronegócio. Essa tabela é aqui apresentada na Figura 1.2 e destaca que com a exportação de tais insumos o Brasil faturou pouco menos de U\$ 38.5 bilhões em 2007; 118.6\% maior que o faturamento em 2003 (pouco mais U\$ 17.5 bilhões).

A partir da Figura 1.1 e da Figura 1.2 podemos destacar a importância do mercado de suco de laranja para o agronegócio nacional, uma vez que a primeira figura revela que o Brasil tem participação em aproximadamente $70 \%$ deste mercado e a segunda figura mostra que o faturamento com as exportações de suco de laranja atingiu pouco mais de U\$ 2.2 bilhões em 2007 (aproximadamente 6\% do faturamento do agronegócio). Dados da Associação Brasileira dos Exportadores de Cítricos (ABECitrus) confirmam, através das suas publicações anuais, que nos últimos 5 anos o Brasil exportou pouco mais de 294 mil toneladas de laranja in natu- 
ra e 6,77 milhões de toneladas de suco de laranja concentrado e congelado (no inglês Frozen Orange Juice Concentrated - FOJC). Além disso, a produção e industrialização dos produtos cítricos têm empregado diretamente cerca de 400 mil pessoas. Devido a esses dados, a citricultura chega a ser responsável por cerca de U\$ 5 bilhões do PIB nacional (1).

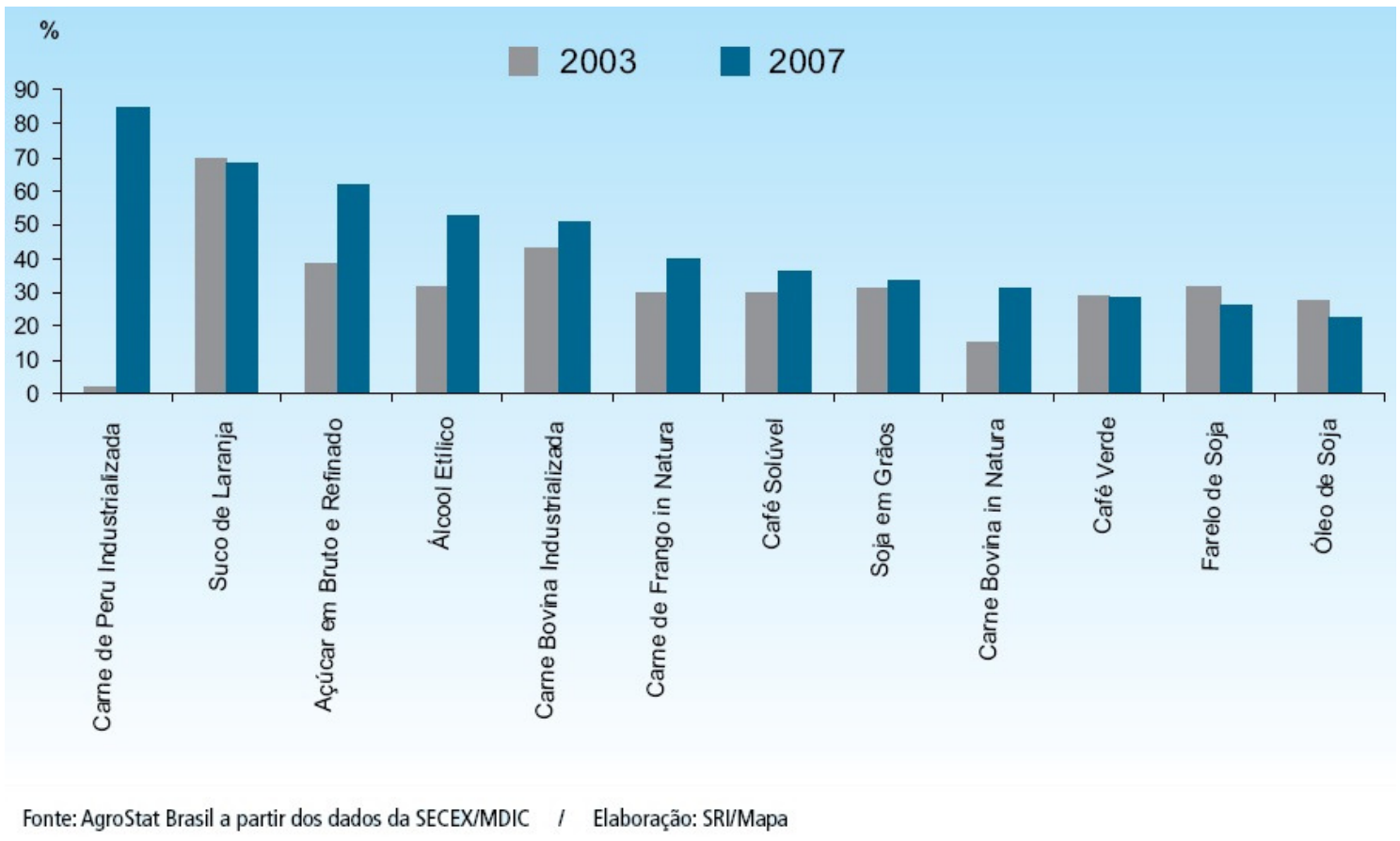

Figura 1.1 - Gráfico da participação percentual do Brasil em alguns mercados de produtos do agronegócio em 2003 e em 2007. Fonte: Brasil, Ministério da Agricultura, Pecuária e Abastecimento. Produtos do agronegócio: exportações, importações mundiais e inserção brasileira. Brasília, DF, 2008. Disponível em: http://www.agricultura.gov.br/images/MAPA//arquivos_portal/ACS/PRODUTOS_DO_AGRONEGOCIO .pdf. Acesso em: 10 de agosto de 2009.

Apesar dos números, as áreas rurais dedicadas ao plantio da laranja vêm diminuindo gradativamente. No Brasil, a área dedicada ao plantio de cítricos chegou a aproximadamente 800 mil hectares em 1999, concentrando cerca de 200 milhões de árvores plantadas; atualmente é de aproximadamente 700 mil hectares e 180 milhões de árvores plantadas. O estado de São Paulo, que atualmente representa $80 \%$ da produção nacional de laranjas, dedica 570 mil hectares ao plantio de culturas cítricas. Um dado favorável à indústria é que apesar da área destinada ao cultivo cítrico ter reduzido $27 \%$, a produtividade por hectare no estado de São Paulo cresceu cerca de $20 \%$ entre os anos de 1999 e 2006 (29).

As causas para redução da área de plantio são basicamente a rotatividade de culturas e a diminuição da produtividade das plantas adultas causada por doenças cítricas. Dentre as principais doenças cítricas destacamos o cancro cítrico (25), a Clorose Variegada dos Citros 
(CVC ou amarelinho) (63) e o Huanglongbing dos citros (HLB ou greening) (14,24). Essas doenças são as principais responsáveis pela diminuição da produção de frutos cítricos em pomares comerciais e não-comerciais.

\begin{tabular}{|c|c|c|c|}
\hline \multicolumn{4}{|c|}{ Valor das Exportaçס̃es Brasileiras dos Produtos Analisados em 2003 e 2007} \\
\hline Nome do Produto & $\begin{array}{c}\text { Exportaçסes } 2003 \\
\text { (em US\$ 1000) }\end{array}$ & $\begin{array}{c}\text { Exportaçסes } 2007 \\
\text { (em US\$ 1000) }\end{array}$ & $\Delta \%$ \\
\hline Carne de Peru Industrializada & 1.912 & 249.941 & 12975,0 \\
\hline Suco de Laranja & 1.192 .980 & 2.251 .790 & 88,8 \\
\hline Açúcar em Bruto e Refinado & 2.140 .002 & 5.100 .437 & 138,3 \\
\hline Álcool Etilico & 158.016 & 1.477 .685 & 835,1 \\
\hline Came Bovina Industrializada & 338.344 & 693.992 & 105,1 \\
\hline Carne de Frango in natura & 1.709 .744 & 4.217 .467 & 146,7 \\
\hline Café Solúvel & 229.098 & 482.038 & 110,4 \\
\hline Soja em Gräos & 4.290 .443 & 6.709 .381 & 56,4 \\
\hline Carne Bovina in natura & 1.154 .510 & 3.485 .726 & 201,9 \\
\hline Café Verde & 1.302 .747 & 5.118 .303 & 292,9 \\
\hline Farelo de Soja & 2.602 .521 & 2.958 .778 & 13,7 \\
\hline Oleo de Soja & 1.232 .550 & 1.719 .710 & 39,5 \\
\hline Carne de Frango Industrializada & 89.209 & 402.150 & 350,8 \\
\hline Carne de Peru in natura & 152.316 & 140.348 & 7,9 \\
\hline Carne Suína in natura & 526.576 & 1.162 .045 & 120,7 \\
\hline Leite Condensado & 25.511 & 41.361 & 62,1 \\
\hline Milho & 369.623 & 1.882 .114 & 409,2 \\
\hline Carne Suína Industrializada & 4.303 & 15.060 & 250,0 \\
\hline Café Torrado & 12.876 & 26.702 & 107,4 \\
\hline Outras Preparaçōes para Animais & 19.410 & 85.188 & 338,9 \\
\hline $\begin{array}{l}\text { Leite em Pó (inclui Creme de leite em } \\
\text { Pól }\end{array}$ & 10.351 & 181.626 & 1654,7 \\
\hline Alimento para Cães e Gatos & 13.821 & 19.012 & 338,9 \\
\hline Queijos & 6.800 & 25.724 & 278,3 \\
\hline Total & 17.583 .663 & 38.446 .578 & 118,6 \\
\hline
\end{tabular}

Figura 1.2 - Tabela com o montante de divisas financeiras geradas pela exportação alguns produtos do agronegócio em 2003 e em 2007. Fonte: Brasil, Ministério da Agricultura, Pecuária e Abastecimento. Produtos do agronegócio: exportações, importações mundiais e inserção brasileira. Brasília, DF, 2008. Disponível em: http://www.agricultura.gov.br/images/MAPA//arquivos_portal/ACS/PRODUTOS_DO_AGRONEGOCIO .pdf. Acesso em: 10 de agosto de 2009.

A CVC, que é causada pela Xylella fastidiosa, só ocorre em laranjeiras e propicia o entupimento dos vasos do xilema devido à multiplicação das bactérias, diminuindo o transporte de nutrientes e água da raiz para as folhas e frutos. A consequiência direta é a diminuição, o amadurecimento precoce e o enrijecimento dos frutos, o que pode torná-los impróprios para o consumo (23). 
Já o greening é considerado a pior doença cítrica até o momento. É uma doença centenária, os primeiros relatos de contaminação da doença datam do início do século XX na China. No Brasil, os primeiros sintomas de infecção datam de 2004. Todas as variedades comerciais podem ser contaminadas pelo greening. As plantas contaminadas produzem menos frutos; além disso, esses frutos são menores, mais ácidos e produzem menos suco que os frutos de plantas sadias (49).

O cancro é uma das doenças cítricas severas com maior índice de ocorrência no mundo. Acredita-se que sua origem tenha ocorrido na Ásia e a transferência para os demais continentes tenha sido por material infectado. Os primeiros relatos de ocorrência no Brasil datam do final da década de 1950 no interior do estado de São Paulo. Nos anos seguintes a doença se disseminou para os estados da região Sul, Mato Grosso do Sul e Minas Gerais. Atualmente, há relatos de cancro cítrico na região Norte, inclusive (31). Todas as variedades comerciais podem ser contaminadas pelo cancro cítrico, mas há uma ordem de susceptibilidade à doença em função da variedade. Os frutos das plantas contaminadas por cancro podem apresentar lesões com pequenas rachaduras, o que pode levar à aceleração do processo de podridão caso bactérias do ambiente se alojem dentro do fruto (48).

Devido à severidade nas plantas e frutos, o combate ao greening e ao cancro cítrico é feito por meio de erradicação das plantas, o que também implica danos e prejuízos ao produtor. Em especial para o cancro, a política de erradicação é recomendada em todo território nacional e é obrigatória por lei no Estado de São Paulo. Esse fato nos motivou em estudar o cancro, uma vez que seu diagnóstico precoce minimiza o prejuízo aos produtores.

Há pelo menos três tipos distintos de cancro cítrico. Dentre eles, o cancro cítrico tipo A ou cancro cítrico asiático, o qual é disseminado pela bactéria Xanthomonas axonopodis $p v$. citri é o mais temido. Os seus sintomas são bem característicos. As lesões são locais, circulares com até doze milímetros de diâmetro e necróticas, apresentando ocasionalmente um halo amarelado em volta da necrose; podem ocorrer nas folhas, nos ramos e nos frutos (31). Do ponto de vista econômico os danos causados exclusivamente pelo cancro cítrico não estão calculados, mas sabe-se que as conseqüências dependem do grau de severidade da doença. Em estágios menos severos, o cancro cítrico leva à formação defeituosa dos frutos, que apresentam lesões necróticas; a consequiência direta é a exclusão do mercado de frutas in natura. Em estágios mais severos, o cancro cítrico induz a queda prematura dos frutos e a desfolha da árvore $(31,66)$. 
Em todo estado de São Paulo e na região do triângulo mineiro em Minas Gerais a coordenação da campanha de combate ao cancro cítrico fica sob responsabilidade do Fundo de Defesa da Citricultura - FUNDECITRUS. Este fundo é credenciado ao MAPA para monitoramento de pragas e doenças além de auxiliar às Secretarias de Agricultura na erradicação das pragas dos citros. Os resultados anuais do FUNDECITRUS têm mostrado o controle do cancro cítrico nos últimos anos. Atualmente, menos de $0,2 \%$ das plantas do estado de São Paulo estão contaminadas; em 1999 a disseminação da doença chegou a atingir 0,7\% do total de plantas do estado de São Paulo (7,51).

No estado de São Paulo a legislação vigente determina que todas as plantas de um talhão sejam erradicadas caso mais de $0,5 \%$ das plantas estejam infectadas. Menos que isso implica erradicação das plantas num raio de $30 \mathrm{~m}$ em torno do foco (60).

Para obedecer à lei, há uma metodologia bem definida para o diagnóstico do cancro nas plantações. Inicialmente os inspetores de campo do FUNDECITRUS fazem uma inspeção das plantas a $20 \%$, ou seja, olham uma planta em um conjunto de cinco. Caso algum sintoma seja encontrado, o diagnóstico é refeito em 100\% das plantas Devemos destacar que em geral se procura entre 200 e 500 folhas em um conjunto de 20.000; além disso, vários fatores influenciam o julgamento do inspetor de campo sobre a presença do cancro na planta, como a experiência do inspetor e a iluminação do ambiente. Uma vez que uma planta é discriminada como infectada uma amostra é enviada a um laboratório credenciado pelo Governo do Estado de São Paulo para confirmar o diagnóstico do cancro cítrico.

Nos laboratórios as técnicas utilizadas com mais freqüência são duas, por isolamento da bactéria existente nas lesões e posterior reprodução em meios de cultura específicos ou por técnicas de PCR (Polymerase Chain Reaction) onde é realizada a leitura do DNA da bactéria e comparada a um banco de dados $(22,25,31)$. Em ambos, um protocolo extenso de atividades deve ser executado antes do diagnóstico final. Eventualmente tais atividades aumentam o tempo de resposta do exame; uma vez que há um número considerável de amostras a serem testadas, mais atrasada será a confirmação do diagnóstico. Vale lembrar que é o número de amostras infectadas que determina a área a ser erradicada.

Atualmente, esse atraso na confirmação do diagnóstico tem sido um gargalo no combate ao cancro, pois atrasa a erradicação e permite a proliferação da praga. Do ponto de vista da logística, o combate ao cancro cítrico se encontra em uma situação complexa, pois há duas atividades no processo de detecção: Um é a sintomatologia da doença, a ser realizada por inspetores através de exame visual ainda na fazenda. A outra é a confirmação do diagnóstico por 
uma técnica mais sensível, específica e com alto índice acerto. Apenas depois destas a erradicação das árvores contaminadas pode ser iniciado. Se houver um método que possibilite o diagnóstico do cancro ainda nas fazendas e com uma taxa de acerto similar às dos laboratórios credenciados o combate ao cancro seria mais efetivo.

Essa é a linha de objetivos deste trabalho, que propõe aplicar técnicas de espectroscopia da fluorescência em amostras contaminadas por cancro cítrico e outras doenças visando uma nova técnica de diagnóstico do cancro, com uma instrumentação robusta que pudesse ser utilizada diretamente fazendas.

Inicialmente a espectroscopia da fluorescência foi utilizada para estudar mecanismos básicos das plantas na primeira metade do século XX (4). Porém, apenas nos últimos 25 anos ela tem sido aplicada significativamente em estudos com plantas e culturas agrícolas, havendo um maior número de publicações a partir da metade da década de 80 (12).

$\mathrm{Na}$ década de 80 os equipamentos comuns para detecção da fluorescência eram fluorímetros. Eles se baseavam em lâmpadas para induzir a fluorescência e detectavam a emissão em determinadas bandas espectrais específicas, fornecendo como resultado o valor da detecção nas bandas ou de razões entre as detecções. Eventualmente os fluorímetros necessitavam operar em um ambiente com controle térmico e da umidade, o que limitava a realização de estudos da espectroscopia da fluorescência em ambientes controlados, como os laboratórios (12).

Porém, nos últimos anos, a evolução da fotônica tem propiciado componentes mais robustos, eficazes e miniaturizados. Exemplo desses são os sistemas LASER, os cabos de fibras ópticas e os monocromadores. Tal evolução levou ao desenvolvimento de novos sistemas como os espectrômetros, que fornecem a informação da fluorescência em uma ampla região espectral (região do visível, por exemplo), e os sistemas de imagem que oferecem informação espacial e espectral do sinal emitido pela amostra. Atualmente já é possível utilizar tais sistemas fora do laboratório, onde as condições ambientais são menos controladas.

Essas informações confirmam que é possível propor um método totalmente óptico para detecção do cancro diretamente no campo. O foco principal é discriminar o cancro das outras doenças existentes em um pomar, uma vez que esse é um dos principais problemas. Outro desafio é desenvolver e aplicar a instrumentação necessária para que tal método seja eficiente.

Assim, o capítulo 2 apresentará uma revisão sobre as técnicas aplicadas de espectroscopia da fluorescência induzida por LASER (no inglês, Laser Induced Fluorescence - LIF), 
destacando o resultado típico da fluorescência da clorofila em amostras como folhas e a forma de análise do resultado obtido.

No capítulo 3 será tratada a instrumentação utilizada neste trabalho, suas vantagens e limitações. Destacamos que este capítulo apresenta sistemas de espectroscopia da fluorescência à fibra e por imagens, os quais têm características particulares, como os componentes, a área de teste, o resultado obtido e a forma de análise.

No capítulo 4 serão apresentados os resultados obtidos utilizando a LIF. Aqui se destaca o panorama inicial em que a pesquisa se encontrava, quando os experimentos eram realizados no laboratório, além dos resultados promissores e das mudanças que seriam necessárias caso desejássemos aumentar a eficiência no diagnóstico. Em seguida são apresentados os resultados com uma nova metodologia, onde a espectroscopia foi realizada no campo. Também serão apresentados os avanços obtidos com essa nova metodologia e quais as mudanças necessárias para melhorar ainda mais a técnica. Aqui, percebemos a necessidade de trabalhar com imagens e não mais com espectros da fluorescência em pontos específicos das lesões do cancro.

No capítulo 5 será apresentada a metodologia e os resultados quando imagens espectrais do cancro são estudadas. Neste capítulo duas técnicas diferentes são aplicadas para realizar a espectroscopia das imagens da fluorescência. Analisamos seus resultados e limitações no nosso estudo.

Por fim as conclusões são apresentadas no capítulo 6, que também relata as publicações obtidas e ainda pretendidas bem como os trabalhos futuros que dão sequiência ao estudo. 


\section{REVISÃO DA LITERATURA}

Este capítulo é dedicado a uma revisão dos métodos e experimentos que envolvem estudos da espectroscopia às plantas. Basicamente duas propriedades ópticas têm sido estudadas, a refletância e a fluorescência, e há duas principais formas de análise da propriedade óptica, com resolução espectral apenas (neste caso a espectroscopia a fibra) ou com resolução espacial e espectral (neste caso a espectroscopia por imagens).

\subsection{ESPECTROSCOPIA DE REFLETÂNCIA E FLUORESCÊNCIA}

\subsubsection{Espectroscopia da refletância}

Certamente a refletância é um dos fenômenos ópticos mais presentes no nosso cotidiano; como nem todo objeto emite luz própria, a refletância é um dos fenômenos que permite que objetos sejam observados e apresentem cores diferentes. As teorias de reflexão da luz são inicialmente estudadas no curso de óptica, durante a formação básica dos físicos e engenheiros. Tal disciplina trata a refletância do ponto de vista macroscópico e utiliza um modelo didático onde um feixe de luz atravessa uma interface uniforme entre dois meios; esse modelo explica a "Lei da Reflexão", onde os ângulos de incidência e de reflexão da luz sobre a superfície devem ser iguais desde que a superfície seja lisa, e a "Lei de Snell da refração" que determina o ângulo de entrada do feixe de luz dentro do meio. Tais teorias, em conjunto com as teorias eletromagnéticas, utilizam as propriedades ópticas dos materiais, em especial o índice de refração (velocidade de propagação da luz dentro da matéria), e as propriedades geométricas do feixe para determinar a parte de luz refletida pela interface. Um exemplo é a incidência de um feixe de luz que se propaga no ar e incide perpendicularmente sobre uma superfície lisa; neste caso o coeficiente de reflexão da superfície para o feixe incidente pode ser calculado pelo quadrado da razão entre a diferença e a soma dos índices de refração dos meios.

Do ponto de vista microscópico a refletância ocorre devido à absorção e o espalhamento da luz pela estrutura eletrônica da matéria. A absorção revela a capacidade de absorção de luz e o espalhamento representa a capacidade da matéria mudar o seu caminho óptico. A 
combinação destes fenômenos faz com que a matéria absorva, transmita ou reflita a luz incidente. A refletância é a quantidade de luz que é devolvida pela matéria ao ambiente e pode informar claramente sobre as condições da superfície (rugosidade) ou sobre as condições internas do material, quando a absorção e o espalhamento variam com a profundidade $(13,33)$.

No estudo científico das plantas a refletância tem sido utilizada para informar sobre a variação na concentração dos pigmentos da planta, uma vez que cada pigmento reflete uma cor diferente. Em geral o conteúdo de pigmentos informa sobre o status da planta. Como exemplo, temos as clorofilas, que absorvem luz na região espectral do azul e do vermelho e refletem coloração verde. O conteúdo das clorofilas pode ser relacionado com a concentração de nutrientes, eficiência fotossintética ou com estresses. Outros exemplos de pigmentos são: carotenóides (coloração amarela), cianinas (vermelho), flavonóides (amarelo) (17,56).

A refletância começou a ser aplicada às culturas agrícolas em 1964 para detecção de umidade em grãos; sua viabilidade permitiu o contínuo estudo sobre o conteúdo de água, proteínas e gordura em produtos agrícolas (26). Nos dias atuais a refletância pode ser estudada através de valores pontuais, espectros ou imagens e as aplicações são diversas. A espectroscopia da refletância foi aplicada em estudos de plantas e matéria seca, além de propriedades da micro-estrutura das plantas e vegetais, como a rigidez e os danos internos (26,53). Nas frutas, a espectroscopia da refletância foi usada para verificar a qualidade de culturas como abacaxi, manga, maçãs, melão, kiwi, entre tantas outras (53). Um trabalho de destaque foi o realizado por Balasundaram e colaboradores que estudou a luz visível e infravermelha refletida por toranjas (citrino híbrido derivado da laranja) para discriminar o cancro cítrico de outras doenças contidas na casca do fruto; sua intenção foi selecionar as amostras contaminadas com cancro cítrico antes de transportá-las para o mercado de consumo (6). Neste estudo o autor conseguiu discriminar todas as toranjas contaminadas por cancro cítrico.

Imagens da refletância estão associadas às características visuais de uma amostra, que são interpretadas pelo o sistema visual humano explorando as cores e intensidades presentes no campo visual. Considerando o registro das imagens por instrumentos, as imagens da refletância foram inicialmente utilizadas no início do século XX por fotografias aplicadas no registro de fungos. Até o final do século XX as fotografias foram largamente utilizadas em diversas aplicações, desde os estudos da anatomia das plantas por microscopia à fotografia aérea de plantações utilizando mini-aeronaves ou satélites (55). A limitação da fotografia estava no uso de filmes específicos para registro em cada região espectral e nas imagens policromáticas (várias cores na mesma imagem), assim apenas as cores mais intensas eram registradas. 
Com a digitalização das imagens aumentou o interesse por processamentos que exploravam a intensidade e/ou a cor refletida. Com a inovação de sistemas de imagens monocromáticas a refletância passou a ser estudada em bandas espectrais específicas. Atualmente, as imagens da refletância no visível e/ou no infravermelho têm sido aplicadas na detecção de defeitos em frutas colhidas e de sintomas de estresses em folhas $(2,19,43)$.

Em especial destacamos os trabalhos desenvolvidos para detecção de contaminantes fecais e defeitos em maçãs $(11,19,38,40-41,67)$ e detecção de defeitos em frutas cítricas $(2,9$ 10,57). Tais trabalhos apresentam instrumentação e processamento de imagens que exploram a coloração da casca das frutas, refletância no infravermelho ou ainda as formas geométricas da fruta e dos defeitos para selecionar as amostras defeituosas. Esses instrumentos são importantes para seleção de frutas de consumo in natura. A qualidade ou a detecção de defeitos também já foi estudada em outras culturas, como mamão papaya, uvas, kiwi, e outras (43).

Ainda na citricultura destacamos os trabalhos de Qin e colaboradores (2008) que estudaram os sintomas do cancro cítrico e de outras doenças na casca de toranjas através de imagens. O objetivo dos pesquisadores era discriminar as lesões de cancro, o qual foi possível através das imagens da refletância no visível $(553 \mathrm{~nm}, 667 \mathrm{~nm})$ e no infravermelho $(718 \mathrm{~nm}$, $818 \mathrm{~nm}$ ). A análise dos componentes principais 3-D foi aplicada às imagens; os melhores resultados revelaram 92\% de acertos na discriminação do cancro cítrico (59). Na continuação do trabalho os pesquisadores aplicaram o método de divergência da informação espectral para classificar o cancro. Neste a taxa de precisão da classificação subiu para 96\% (58).

Imagens da refletância utilizando espectrógrafos também têm sido amplamente utilizadas em associação com aeronaves e satélites em estudos de sensoriamento remoto do meio ambiente, deficiências de minerais em plantações agrícolas e no solo (20,32,35-36). Nestes casos a técnica utiliza o movimento do meio de transporte como sistema de varredura sobre a área de interesse; uma vez que o meio de transporte está distante do objeto, é o poder de amplificação das lentes usadas no sistema que determinam a resolução espacial do seu campo de visão.

A desvantagem da refletância é a falta de especificidade dos compostos que contribuem com medida, uma vez que a mudança na concentração de alguns pigmentos pode levar ao mesmo sintoma visual. É por esse motivo que doenças distintas causadas por agentes diferentes induzem sintomas semelhantes, como no caso de algumas doenças cítricas (31). 


\subsubsection{Espectroscopia da fluorescência}

A fluorescência é um fenômeno óptico que ocorre em uma molécula depois da mesma absorver fótons do ambiente. Fisicamente os fótons absorvidos pela estrutura eletrônica elevam a energia dos elétrons da molécula a estados quânticos excitados e menos estáveis. Buscando maior estabilidade, a molécula passa a dissipar a energia acumulada por processos de decaimento radiativo e/ou não-radiativo. Os processos de decaimento radiativo envolvem a emissão de fótons enquanto os processos não-radiativos não envolvem. Os processos nãoradiativos envolvem vibrações, rotações e translações da biomolécula ou ainda transferência de energia para as moléculas vizinhas através de choques (4).

Nos processos radiativos a emissão de fótons pode depender dos estados quânticos singleto ou dos estados quânticos singleto e tripleto da molécula. Quando dependem apenas dos singletos a emissão é denominada fluorescência, quando dependem dos singletos e tripletos a emissão é denominada fosforescência. Em geral a fluorescência ocorre com maior probabilidade que a fosforescência, por isso é mais comum de ser observada. O tempo de vida é a característica para distinguir a fluorescência da fosforescência. Enquanto a emissão da fluorescência evanesce na ordem de nanosegundos a da fosforescência pode durar até alguns segundos. A causa da diferença é o cruzamento intersistemas (transições entre estados singletos e tripletos) que ocorre na fosforescência, mas não na fluorescência. Devido às suas características a fluorescência é conhecida como uma "assinatura molecular" (4).

Nos estudos científicos da espectroscopia da fluorescência em plantas e culturas agropecuárias algumas biomoléculas já foram estudadas. Entre elas destacamos os carotenos, o ácido ferrúlico, FAD (Flavina adenina dinucleotídeo), NADPH (Nicotinamida adenina dinucleotídeo fosfato, forma reduzida) e o rubisco; estes estão presentes na estrutura da folha e além de exercerem funções bioquímicas são responsáveis pela captura de luz do ambiente (17). Porém o pigmento mais estudado com a espectroscopia da fluorescência são as clorofilas. Ela apresenta a melhor informação bioquímica da planta, pois é o principal pigmento responsável pela fotossíntese.

As clorofilas a e b fazem parte do conjunto de pigmentos presentes na folha que são responsáveis pela coleta de luz do ambiente. Esses pigmentos são divididos em dois grupos devido à sua funcionalidade, os pigmentos acessórios e o pigmento principal. Os pigmentos acessórios têm a única função de absorver a luz do ambiente e entregar a energia para o pig- 
mento principal; esse grupo é formado pelos demais pigmentos da planta, exceto a clorofila a; os mais abundantes são a clorofila b e os carotenóides. O pigmento principal é a clorofila a; ela também absorve luz do ambiente, mas sua principal função é capturar a energia dos pigmentos acessórios e entregá-la aos centros de reação para ocorrência da fotossíntese (42). Por sua vez, os centros de reação da fotossíntese são formados por dois fotossistemas, chamados fotossistema I (FSI) e fotossistema II (FSII).

Para descrever melhor esse processo de transferência de energia do meio ambiente aos fotossistemas apresentamos inicialmente na Figura 2.1 um conjunto de gráficos que contém o espectro de absorção molar (linha pontilhada) e o da fluorescência (linha cheia) induzida por radiação ultravioleta (UV - $355 \mathrm{~nm}$ ) dos principais pigmentos presentes na folha. A partir do gráfico vemos que a radiação UV é a principal radiação para induzir a fluorescência do ácido ferrúlico, NADPH, FAD e do rubisco. Podemos ver também que a fluorescência destes pigmentos ocorre na região entre 400 e $550 \mathrm{~nm}$ e que as clorofilas absorvem fortemente entre 400 e $500 \mathrm{~nm}$ (azul-verde) e entre 600 e 700 nm (vermelho). Outra característica importante é que as próprias clorofilas re-absorvem a sua fluorescência emitida na região espectral do vermelho (17).

Assim sendo, ao absorver fótons do meio ambiente os pigmentos auxiliares tendem a fluorescer na região espectral de absorção das clorofilas. Por sua vez, ao absorver os fótons provindos do meio ambiente e dos pigmentos auxiliares, a clorofila $\mathrm{b}$ tende a transferir toda $\mathrm{a}$ sua emissão para a clorofila a, que em experimentos in vivo passa a ser o único fluoróforo a transferir energia para os fotossistemas $(17,42,52)$. 

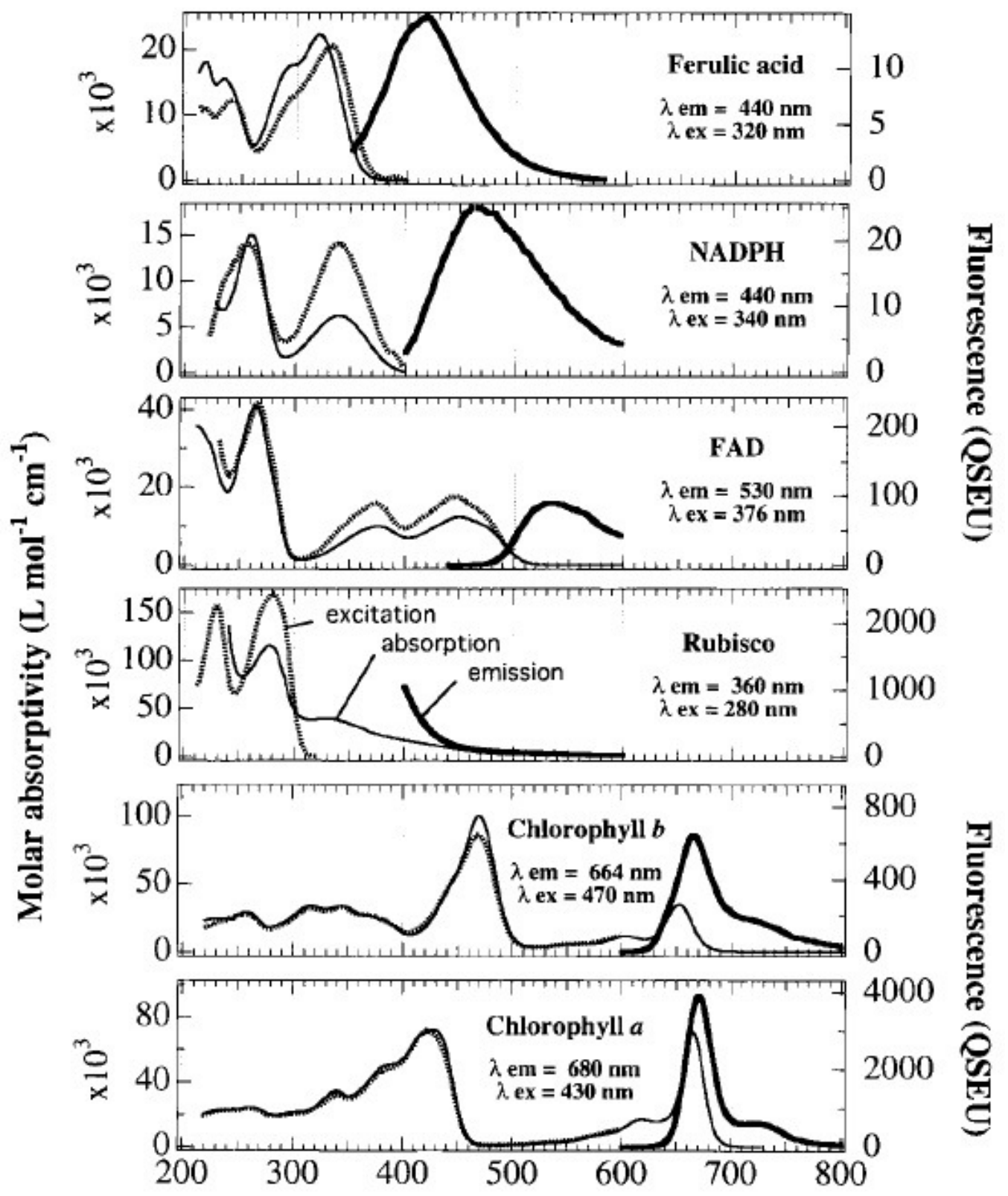

wavelength $(\mathrm{nm})$

Figura 2.1 - Espectros de absorção molar (linha pontilhada) e da emissão da fluorescência (linha cheia) de alguns dos principais pigmentos contidos nas folhas. Destaque para as clorofilas que absorvem na região espectral do azul e do vermelho, logo são os responsáveis pela coloração verde das folhas. Fonte: CEROVIC, Z. G., et al. Ultraviolet-induced fluorescence for plant monitoring: present state and prospects. Agriculture and Environment, v. 19, p. 543-578, 1999.

Complementando o detalhamento apresentamos na Figura 2.2 o espectro de absorção dos fotossistemas na região do visível. Ela mostra que o FSI possui máxima absorção em 700 nm, e por isso o pigmento do seu centro de reação é chamado P700, enquanto que o FSII possui pico de absorção em $680 \mathrm{~nm}$, e o pigmento do seu centro de reação é chamado P680. De 
acordo com a funcionalidade para a fotossíntese, o FSII é o responsável pela fotofosforilação, já o FSI tem a função é formar moléculas de NADPH e de um oxidante que será reduzido com os elétrons originados no FSII. Os gráficos da Figura 2.2 indicam que os fotossistemas absorvem energia na região do vermelho $(670$ a $720 \mathrm{~nm})$, exatamente na região de emissão das clorofilas, de forma que finaliza o processo de transferência da energia da luz do meio ambiente aos fotossistemas. PSI e PSII ainda absorvem luz na região do azul (420 a $450 \mathrm{~nm}$ ), porém nessa região competem por fótons com as clorofilas que evitam que a emissão dos pigmentos auxiliares chegue aos fotossistemas diretamente. Parte da emissão da clorofila que não é coletada pelos fotossistemas retorna ao ambiente na forma de fluorescência da clorofila a $(42,52)$. Para um melhor detalhamento dos mecanismos de ocorrência da fotossíntese recomendamos o livro de D. Lawlor, Photosinthesis, $3^{\circ}$ Edition, 2001 (42).
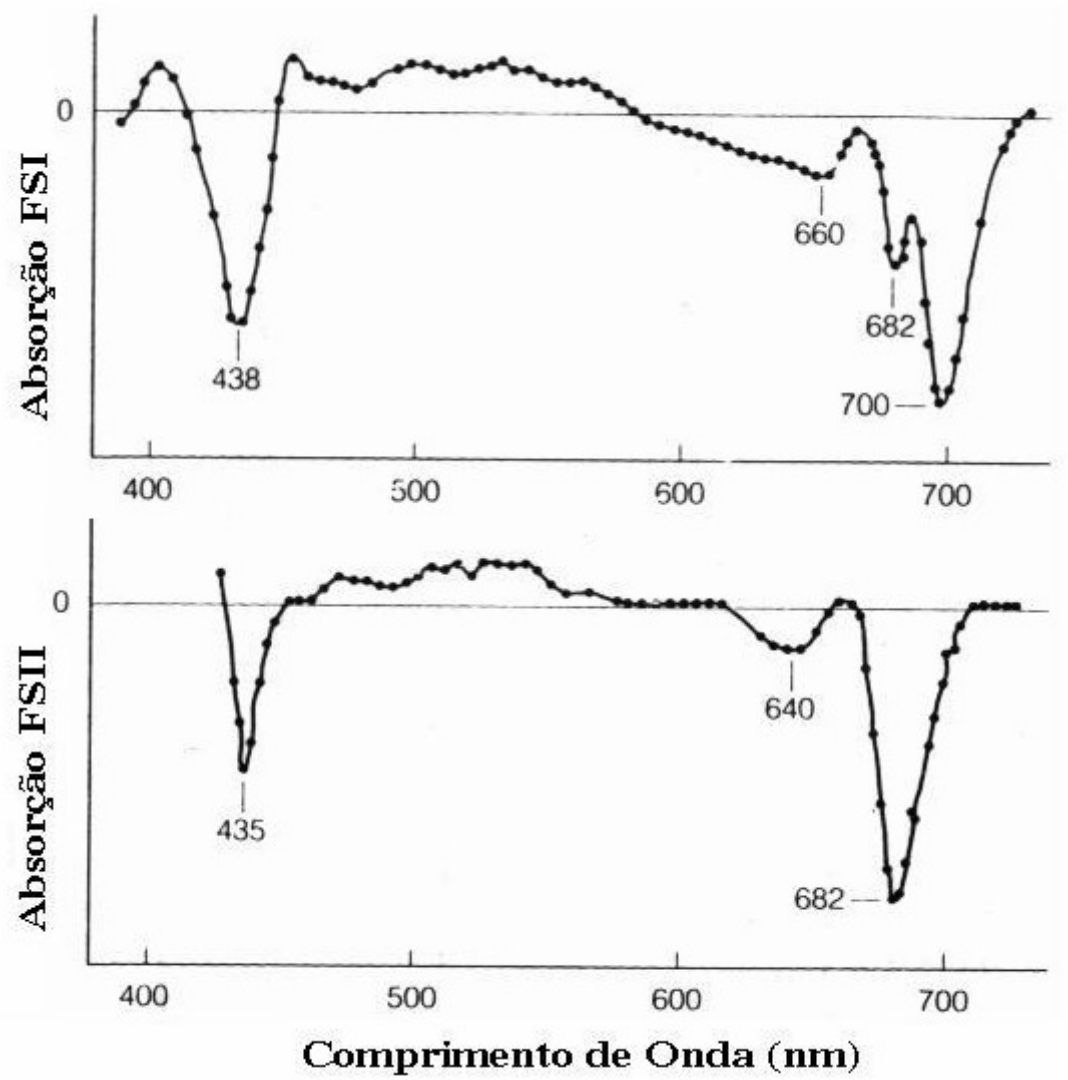

Figura 2.2 - Espectro de absorção dos fotossistemas FSI e FSII responsáveis pela ocorrência da fotossíntese. Fonte: Lawlor, D. Photosintesis, third edition, 2001, S. 39. 
Uma vez que a fluorescência emitida pela clorofila da folha ao meio ambiente depende da concentração de clorofila na amostra e da captura de fótons pelos fotossistemas, pode-se dizer que estudar a fluorescência da clorofila implica estudar, indiretamente, os estados dos aparatos fotossintéticos da planta, e dessa forma é possível identificar a influência das condições ambientais sobre o seu rendimento bioquímico, por exemplo $(17,52)$. Como as clorofilas estão em abundância nas plantas adultas, seu estudo se torna uma alternativa viável para observar mudanças na planta causadas por agentes bióticos ou abióticos, como os danos causados por doenças (17).

A concentração dos pigmentos presentes nas folhas revela a sua característica de absorção de luz. Tal informação pode ser observada na Figura 2.3, que apresenta o espectro de absorção de um extrato alcoólico dos pigmentos contidos nas folhas (linha fina e contínua) além dos espectros da fluorescência emitida por folhas de ervilhas (Pisum sativum L.) (linha pontilhada) e de beterraba (Beta vulgaris L.) (linha cheia e contínua) quando radiação UV $(355 \mathrm{~nm})$ excita os pigmentos. A partir do gráfico é possível destacar que radiações entre 250 e $700 \mathrm{~nm}$ podem ser usadas para induzir a fluorescência dos pigmentos, apesar da baixa absorção de fótons entre 500 e $560 \mathrm{~nm}$. A concentração de pigmentos presentes na folha varia entre as espécies, mesmo assim é possível compreender que ao utilizar luz visível as clorofilas e os carotenóides são os principais pigmentos absorvedores; já ao utilizar radiação UV uma quantidade significante de pigmentos acessórios participa da coleta da luz.

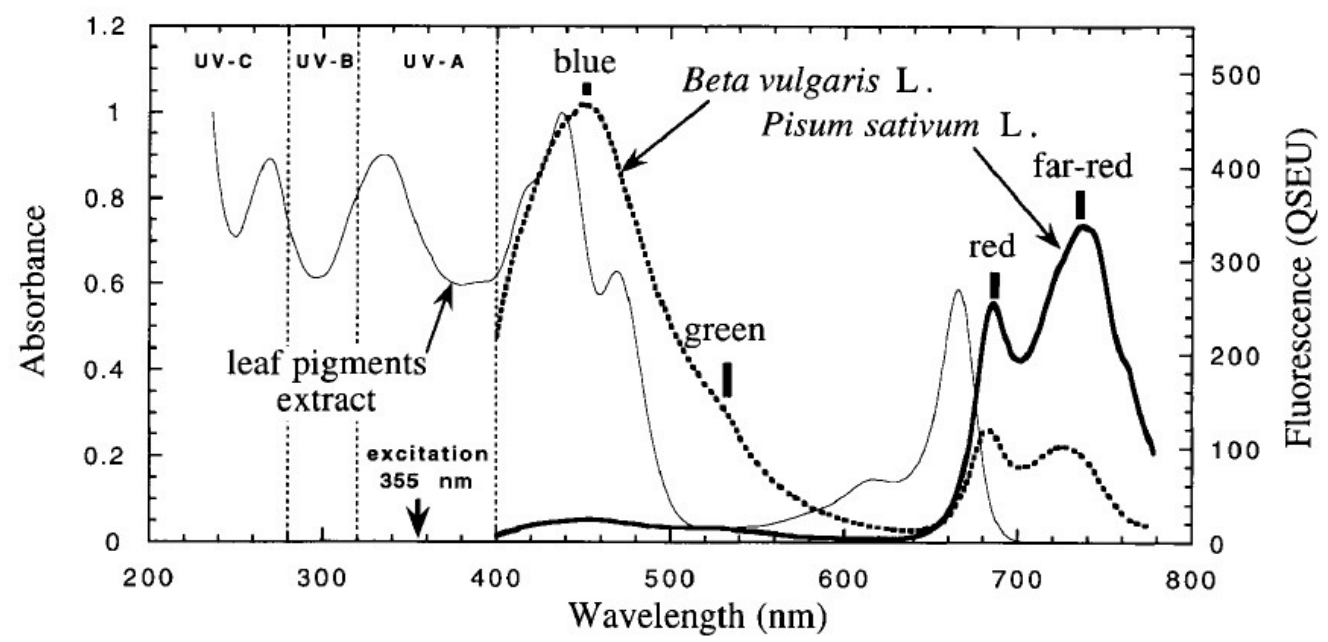

Figura 2.3 - Espectro de absorção de um extrato alcoólico dos pigmentos contidos nas folhas (linha fina e contínua) além dos espectros da fluorescência emitida por folhas de ervilhas (Pisum sativum L.) (linha pontilhada) e por folhas de beterraba (Beta vulgaris L.) (linha cheia e contínua) quando a excitação da fluorescência é realizada em $355 \mathrm{~nm}$. Destaque para as bandas de emissão da fluorescência: blue (azul), green (verde), red (vermelho), far-red (vermelho distante). Fonte: CEROVIC, Z. G., et al. Ultravioletinduced fluorescence for plant monitoring: present state and prospects. Agriculture and Environment, v. 19, p. 543-578, 1999. 
Devido a essa característica e ao fato das lâmpadas halógenas conseguirem emitir alta intensidade de radiação UV a indução da fluorescência da clorofila por UV tem sido amplamente empregada, especialmente nos estudos que envolvem plantas submetidas a estresse biótico ou abiótico (34). A literatura científica informa sobre estudos onde a fluorescência da clorofila induzida por luz UV foi aplicada na discriminação de plantas com deficiência de minerais como o nitrogênio, o potássio, o ferro, o magnésio, entre outros $(3,17-18)$. Além desses, ela foi aplicada na discriminação de plantas em estresse por deficiência de água e por variação da temperatura $(17,28,44,46)$.

Não há muitos estudos envolvendo a aplicação da espectroscopia da fluorescência em produtos ou culturas cítricas; dentre estes poucos relatamos o uso da fluorescência para detecção de resíduos químicos em frutos cítricos (30) e a aplicação da espectroscopia da fluorescência de aminoácidos para classificar sucos de laranja comerciais (62). Vale destacar que nosso grupo é pioneiro em publicações que aplicam a LIF em estudos de diagnóstico do cancro cítrico.

Já as imagens espectrais da fluorescência foram inicialmente aplicadas em estudos de ciência básica sobre a atividade fotossintética das plantas e conteúdo da clorofila nas folhas, dando seqüência aos estudos da espectroscopia utilizando imagens. Nestes trabalhos, de forma semelhante à espectroscopia, os autores estudam as variações de razões da fluorescência emitida $(17,43,45)$. Atualmente sua principal aplicação é na visualização de estresses manifestados nas folhas, especialmente por deficiência de minerais e água ou na busca de discriminação de sintomas de doenças, onde a emissão da fluorescência de amostras contaminadas é comparada à do grupo controle $(16-17,19,43)$. Também há estudos onde as imagens da fluorescência foram aplicadas para verificação da qualidade de frutas. Em especial destacamos os trabalhos para detecção de contaminantes fecais e defeitos em maçãs (39-40). Atualmente na literatura não há relatos de publicações sobre imagens espectrais da fluorescência aplicadas na citricultura. 


\subsubsection{Formas de análise da fluorescência}

Ainda na Figura 2.3, pode-se observar que os espectros de fluorescência apresentados possuem diferentes formas (intensidades), que varia com a espécie, e que ao induzir a fluorescência com luz UV é possível medir o sinal em quase todo espectro visível.

Para estudar a fluorescência emitida por folhas quando induzida por radiação UV não é necessário analisar toda a fluorescência emitida no visível uma vez que a literatura científica privilegia algumas bandas espectrais. A primeira é a região do azul que compreende entre 430 e $450 \mathrm{~nm}$; a fluorescência emitida ali é chamada fluorescência do azul (no inglês blue fluorescence, $\mathrm{BF}$ ) e é representada pela intensidade detectada em $440 \mathrm{~nm}$. Os principais pigmentos fluorescentes nessa região são ácido ferrúlico, NADP+ (Nicotinamida adenina dinucleotídeo fosfato, forma oxidada) e NADPH (16-17). A Figura 2.3 mostra que sob mesmas condições as folhas de beterraba emitem mais fluorescência na região da BF que as folhas de ervilhas por possuírem mais ácido ferrúlico nas suas paredes celulares (17).

A outra banda estudada ocorre na região do verde (no inglês green fluorescence, GF), compreendida na banda $520 \pm 10 \mathrm{~nm}$. Nesta região vários pigmentos são responsáveis pela fluorescência e as clorofilas e os carotenóides são os principais pigmentos absorvedores. A próxima banda de emissão, que compreende a região espectral desde $650 \mathrm{~nm}$ até $800 \mathrm{~nm}$, é chamada de fluorescência da clorofila (no inglês chlorophill fluorescence, ChlF) e depende da concentração de clorofila e/ou da eficiência dos sistemas fotossintéticos da folha $(16-17,42)$.

A ChlF ainda é divida em outras duas regiões, a da fluorescência no vermelho (no inglês red fluorescence, RF) entre $680 \mathrm{~nm}$ e $700 \mathrm{~nm}$ e que depende da transferência de energia da clorofila para o fotossistema PSII; e a da fluorescência do vermelho distante (no inglês far red fluorescence, FRF) entre $730 \mathrm{~nm}$ e $750 \mathrm{~nm}$ e que depende da transferência de energia da clorofila para os fotossistemas PSI e PSII $(17,42,52)$. A Figura 2.3 mostra que nessa região as folhas de ervilhas emitem mais fluorescência que as de beterraba devido à maior concentração de clorofilas na folha (17).

A análise dos espectros se dá verificando as mudanças de intensidade na BF, GF, RF e FRF ou ainda compondo razões entre elas. Em geral a RF/FRF é utilizada para estudos sobre a eficiência fotossintética da planta; já a BF/ChlF ou a GF/ChlF são sensíveis aos estresses que as plantas estão sofrendo, especialmente por déficit de minerais. Essas razões de fluorescência têm sido utilizadas com sucesso como ferramentas de observação de estresse por mu- 
danças na temperatura do ambiente, intensidade de radiação ultravioleta sobre as plantas, estresses que limitam o crescimento, estresse por deficiência de minerais e água, além de doenças (17); diretamente na citricultura as razões da fluorescência foram aplicadas no diagnóstico de plantas com deficiência hídrica $(46)$, em estudos de doenças $(8,50)$ e até na aceleração do processo de senescência de folhas depois de destacadas das plantas (47).

Especialmente para detalhar o nosso estudo, apresentamos na Figura 2.4 um espectro típico da fluorescência emitida por uma folha de laranjeira e induzida por LASER em $532 \mathrm{~nm}$ (luz verde). Na figura é possível identificar tanto o pico da reflexão da luz verde pela superfície da folha, quanto a fluorescência emitida por ela. A informação da reflexão aparece no gráfico porque o espectrômetro não bloqueia toda a luz refletida pela superfície da amostra e a detecta na mesma ordem de grandeza da fluorescência. Já a fluorescência emitida pela folha apresenta os dois picos da ChlF, que já foram explicados. Como a excitação das moléculas é por luz verde, não há detecção da fluorescência emitida nas bandas BF e GF.

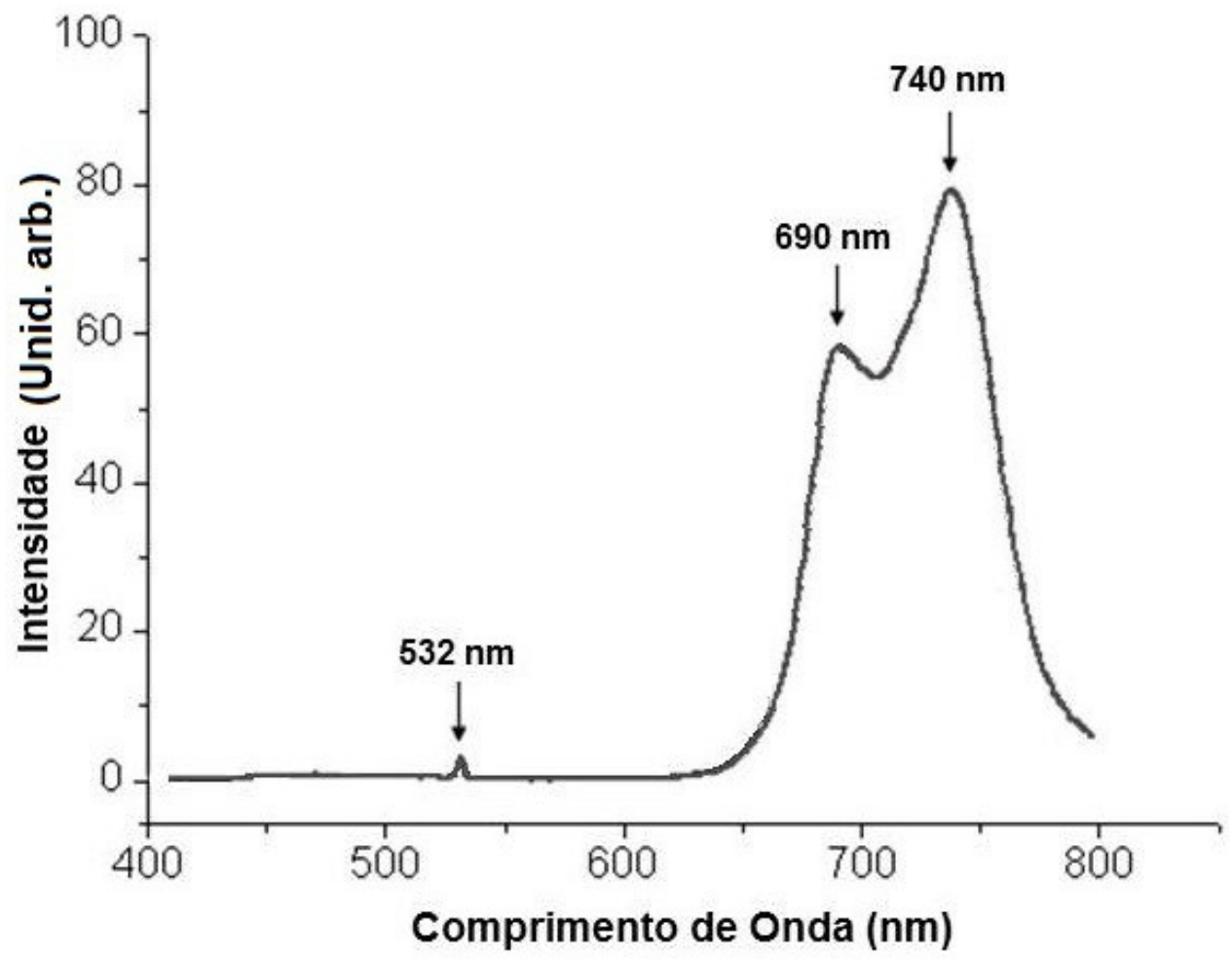

Figura 2.4 - Gráfico de um espectro da fluorescência emitida por uma folha sadia de laranjeira quando a excitação é feita por LASER em $532 \mathrm{~nm}$. Neste típico espectro é possível obter informação sobre a refletância do LASER sobre a superfície da amostra (pico em $532 \mathrm{~nm}$ ) e sobre a fluorescência emitida pela folha. Destaque para os dois picos de emissão da fluorescência, em $690 \mathrm{~nm}$ e $740 \mathrm{~nm}$. 


\subsection{INSTRUMENTAÇÃO}

\subsubsection{Refletância sem fibra}

A radiometria é a técnica mais tradicional de medir a refletância (ou a transmitância) das plantas ou do solo. Nesta técnica o radiômetro pode utilizar tanto luz natural (solar) quanto luz artificial (lâmpadas ou diodos emissores) para realizar a medida. Os radiômetros são basicamente formados por fonte de luz (opcional), uma esfera integradora, filtros ópticos e fotodetectores. Alguns radiômetros utilizam rodas de filtros e um único fotodetector. O resultado do radiômetro está diretamente relacionado com a banda de transmissão dos filtros ópticos; ele pode medir tanto a refletância absoluta quanto a relativa. A refletância absoluta só tem sentido se estiver relacionada com a intensidade de luz natural presente no local da medida; ela informa sobre a luz refletida pela planta ou solo em relação ao horário, estação do ano, ângulo de iluminação, fluxo luminoso, ou algum outro parâmetro da radiometria. A refletância relativa toma como calibração a fonte de luz utilizada, natural ou artificial; dessa forma a refletância em cada banda de detecção é informada em valores percentuais e não depende dos demais parâmetros da radiometria. Por outro lado, a refletância relativa elimina a condição ambiental como ferramenta de análise. Os radiômetros podem ser acoplados em aeronaves, satélites ou podem ser desenvolvidos como peças de mão. As vantagens e desvantagens de cada plataforma estão relacionadas com a área de cobertura por varredura, a resolução espacial, a resolução temporal, a dependência com a presença de nuvens, a dependência com a iluminação local e o controle do usuário (61).

\subsubsection{Refletância e fluorescência com fibra}

A espectroscopia a fibra se baseia na análise de um sinal óptico em regiões espectrais bem definidas, coletando o sinal emitido pela amostra com uma ou mais fibras ópticas que conduzem o sinal óptico para ser detectado. Sendo assim, é o diâmetro da fibra (ou cabo de fibras) quem determina a área de detecção na amostra. 
Em geral a espectroscopia da refletância é estudada em uma larga banda espectral, desde o visível até o infravermelho próximo (400 nm a $2500 \mathrm{~nm}$ ). A refletância no infravermelho próximo informa sobre a composição química da amostra através das bandas de vibração e de rotação dos compostos. É comum essa técnica ser aplicada em soluções de amostras sólidas e em pó $(21,26,53)$. O espectrômetro é o equipamento utilizado na espectroscopia da refletância. Ele é composto por fonte emissora, fibras ópticas, elementos difrativos, componentes ópticos e uma matriz linear de fotodetectores. Alguns deles também possuem uma esfera integradora. Em geral uma lâmpada halógena de tungstênio é usada para emissão em toda a banda estudada, mas também há instrumentos que utilizam diodos emissores como fonte de luz. As fibras ópticas conduzem a radiação deste a fonte à amostra e da amostra ao monocromador. Este último é composto por elementos difrativos, como prismas ou grades de difração, e pela matriz linear de fotodetectores. Uma vez que, tanto os elementos dispersivos como os fotodetectores são produzido para operar ou na região do visível ou na do infravermelho próximo, é necessário um caminho óptico para cada tipo de radiação. No caso dos fotodetectores o material determina a região de detecção. Enquanto o silício é material mais comum para detecção entre 400 e 1100 nm, o InGaAs (Arseneto de gálio-índio) tem sido utilizado para detecção entre 1100 e $2500 \mathrm{~nm}(53,55)$.

Já para as medições da fluorescência, o fluorímetro era o instrumento usado com maior frequiência até o meio da década de 90, a partir de então os espectrômetros têm sido amplamente utilizados. A diferença entre eles está no resultado fornecido. O fluorímetro coleta a fluorescência emitida em pequenas bandas espectrais, por isso sua instrumentação sempre estava associada com figuras de mérito específicas (12). O espectrômetro fornece uma distribuição de intensidades detectadas ao longo de uma região espectral inteira. Atualmente, os espectrômetros mais comuns fornecem a fluorescência detectada em cada comprimento de onda da região entre o visível e parte do infravermelho (400 a 1100 nm) (68). Ambos os sistemas são compostos por fonte de luz para indução da fluorescência, fibras ópticas, elementos difrativos, filtros ópticos para seleção das bandas espectrais e fotodetectores. Tradicionalmente a espectroscopia da fluorescência é realizada a base de LASER como fonte de luz, pois é monocromático (induz a fluorescência seletivamente) e acopla luz na fibra com maior eficiência que as demais fontes de luz; atualmente os diodos emissores de alto brilho surgem como uma alternativa para miniaturização dos sistemas mantendo alta intensidade para excitação das moléculas. 


\subsubsection{Imagens espectrais da refletância e da fluorescência}

Nos últimos anos, o desenvolvimento de sistemas óticos capazes de formar imagens com resolução espectral tem possibilitado maior precisão nos diagnósticos que envolvem a óptica aplicada às culturas agrícolas. Essa modalidade de imagem, a qual combina a técnica da espectroscopia com a formação de imagens digitais é denominada espectroscopia das imagens e permite a análise de sinais ópticos das amostras através de informação espacial e espectral ao mesmo tempo (68). Isto é uma grande vantagem quando comparada às técnicas tradicionais de espectroscopia, as quais só permitem o estudo de uma área muito pequena da amostra.

Uma vez que as imagens necessitam de uma distribuição bi-dimensional de intensidades, a forma mais didática de apresentar a espectroscopia das imagens é através de um cubo de dados espectrais, como mostrado na Figura 2.5. Este cubo é composto por $n$ imagens bi-dimensionais da amostra, concatenadas e em seqüência crescente com a banda espectral de detecção $(\lambda)$. O número $n$ de imagens determina o número de bandas espectrais em que o sinal óptico foi detectado; por exemplo, na Figura 2.5 são compostas 4 imagens capturadas em 4 bandas espectrais. Cada uma das 4 imagens é chamada imagem espectral. Os dados do cubo estão dispostos de forma que cada um dos pixels das imagens na mesma posição $(i, j)$ pertencem a um espectro do sinal óptico detectado na posição $(i, j)$ da imagem. Há duas formas de compor as imagens espectrais: mantendo o campo de visão fixo e varrendo a detecção espectral ou mantendo a detecção espectral fixa e varrendo o campo de visão.

Com exceção do elemento óptico que propicia a varredura os demais componentes são os mesmos para ambas as formas de compor imagens espectrais: lentes objetivas, fontes de excitação das moléculas e uma câmera para detecção. As lentes objetivas são responsáveis pelo campo de visão do sistema que varre desde áreas microscópicas, onde estruturas celulares são observadas, até imagens de satélites, onde o campo de visão pode ser de quilômetros. A fonte de excitação das moléculas deve ser intensa o suficiente para garantir altas intensidades de iluminação sobre a amostra independente da área de interesse; eventualmente as lâmpadas têm sido utilizadas, atualmente os diodos de alto brilho também surgem como alternativa. A câmera de detecção é um dos mais importantes componentes do sistema, pois está diretamente associado à intensidade do sinal estudado e à resolução temporal do sistema. Câmeras mais sensíveis (com resfriamento do sensor, controle de 
exposição e ganho de detecção) são usadas para detectar baixos sinais ópticos, como a fluorescência; evidentemente tais câmeras são mais caras. Para a refletância não há necessidade de câmeras tão sensíveis, pois em geral o sinal da refletância está na ordem de grandeza da fonte emissora (68).

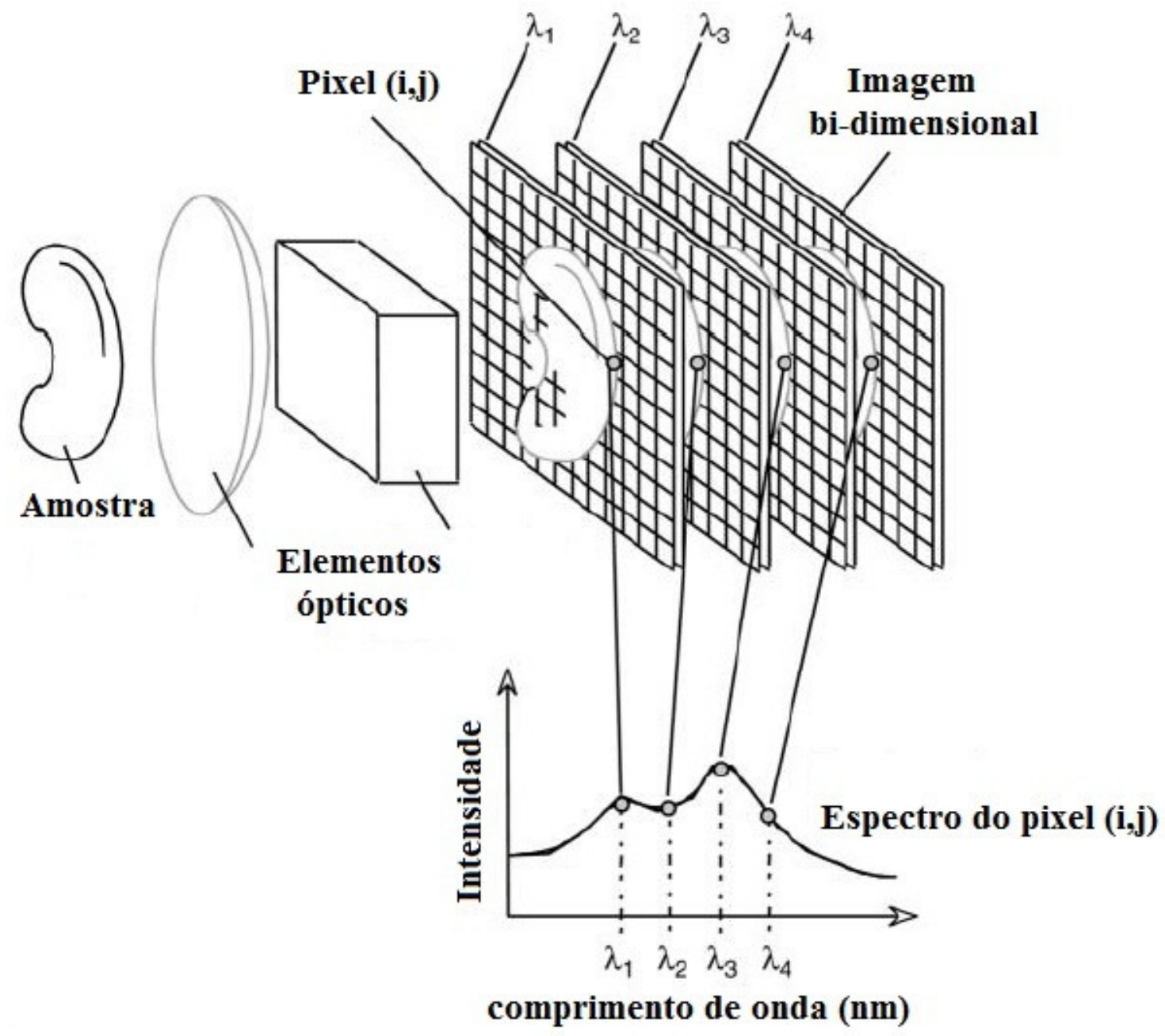

Figura 2.5 - Cubo de dados espectrais que revela o comportamento de uma propriedade óptica de uma amostra experimental com resolução espectral e espacial. Adaptada da figura 6.15 do livro Biomedical Photonics Handbook, CRC Press, 2003. Fonte: VO-DIHN, T. Biomedical Photonics Handbook. Boca Raton: CRC Press, 2003. 


\subsubsection{Imagens com varredura espectral}

Nesta forma de compor imagens espectrais é necessária a utilização de um elemento óptico que possibilite sintonizar uma banda espectral de detecção da fluorescência sem mudar o campo de visão do sistema. Exemplos desses elementos são as rodas com filtros ópticos passa-banda e os filtros ópticos sintonizáveis. As rodas de filtro são elementos mecânicos que selecionam a banda de detecção deslocando filtros ópticos passa-banda. A roda com filtros é controlada por computador e qualquer filtro óptico passa-banda de vidro dopado, polímero, ou filtro de interferência pode ser acoplado. Neste caso a qualidade do filtro determina a resolução espectral da imagem; em geral os filtros ópticos comerciais apresentam um pico de transmissão máxima e uma largura espectral de banda variando entre 10 e $20 \mathrm{~nm}$. O pico caracteriza a banda de transmissão do filtro. Uma alternativa aos filtros ópticos passa-banda são os filtros sintonizáveis, que controlam eletronicamente a banda espectral passante sem movimento das partes. Os mais comuns são os filtros sintonizáveis com cristal líquido (no inglês Liquid Cristal Tunable Filter, LCTF) que são baseados nos filtros de Lyot e utiliza placas de quartzo como elemento birrefrigente para selecionar a banda espectral passante. Esse filtro consegue selecionar bandas de transmissão em regiões espectrais bem definidas como o visível (400 a $720 \mathrm{~nm})$ ou o infravermelho próximo $(650$ a $1100 \mathrm{~nm})$ transmitindo bandas com largura variando entre 1 e $20 \mathrm{~nm}(68)$.

\subsubsection{Imagens com varredura espacial}

Os sistemas de imagens espectrais com varredura espacial se baseiam em manter a detecção espectral constante e variar o campo de visão do sistema. Para isso necessitam o uso de espectrógrafos, elementos ópticos que dispersam o sinal óptico do campo de visão formando as imagens. Em geral os espectrógrafos são formados por conjuntos de grades de difração, conjuntos de prismas ópticos ou cristais não-lineares, para qualquer um desses elementos é necessário reduzir o campo de visão do sistema para evitar a sobreposição da informação espacial com a espectral; a redução do campo de visão implica a necessidade de varrer o sistema sobre a amostra caso a região de interesse na amostra seja maior que o campo de visão do 
sistema $(16,19)$. É a redução do campo de visão que determina a resolução espectral do sistema.

Um exemplo de composição de imagens espectrais com varredura do campo de visão é apresentado na Figura 2.6 e foi obtido da referência (19). Nesta figura as amostras são maçãs (Figura 2.6a) e o sistema de imagens é composto por um espectrógrafo que varre as amostras em linha. O resultado de uma imagem do espectrógrafo é mostrado na Figura 2.6b; ela apresenta a variação de intensidades do sinal óptico na região espectral entre 400 e $1000 \mathrm{~nm}$ e espacial ao longo do campo de visão descrito pela linha branca na Figura 2.6a. Varrendo o sistema sobre toda a região de interesse é possível compor as imagens espectrais da refletância ou da fluorescência; a partir dessas são calculadas as imagens das razões da refletância (Figura 2.6c) ou da fluorescência (2.6d).

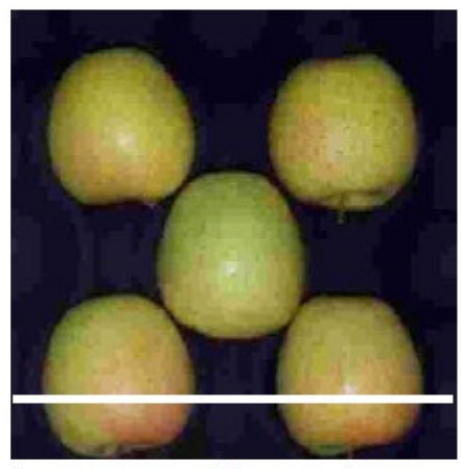

(a)

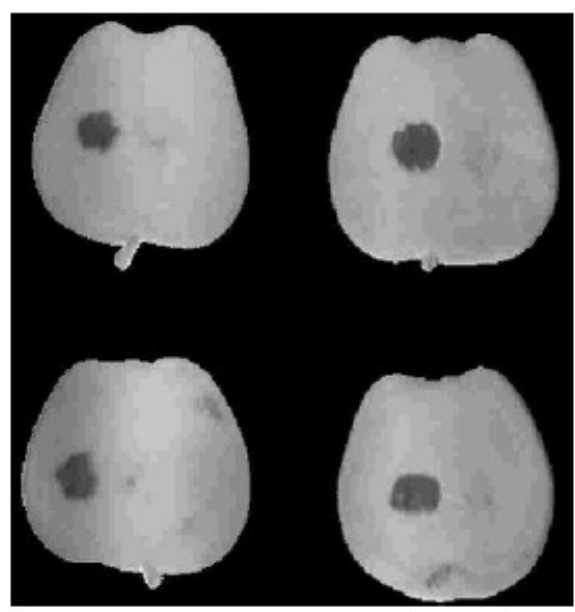

(c)

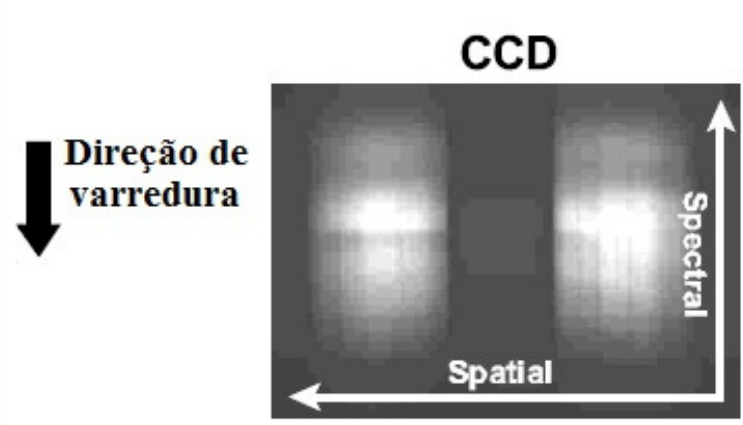

(b)

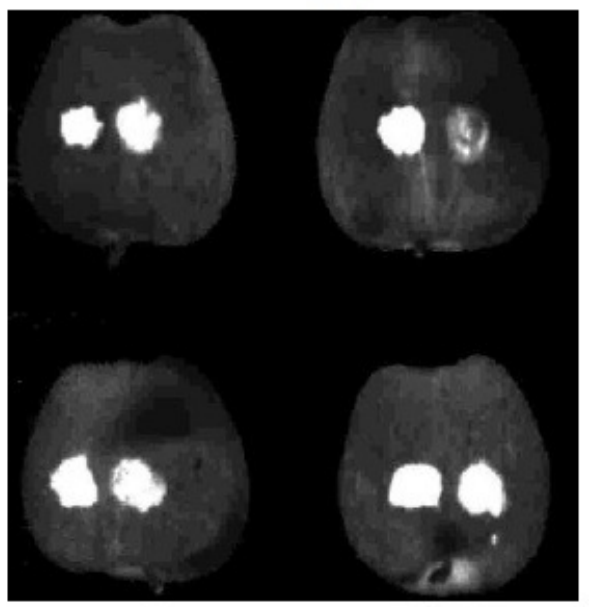

(d)

Figura 2.6 - Exemplo de composição de imagens espectrais com varredura espacial. (a) Região de interesse estudada e o campo de visão (linha branca) do sistema. (b) Imagem do espectrógrafo capturada pela câmera com informação espacial e espectral do campo de visão da figura (a). Os resultados do experimento são imagens da razão de imagens espectrais da refletância (c) e da fluorescência (d) das amostras. Fonte: CHEN, Y; CHAO, K.; KIM, M. S. Machine vision technology for agricultural Applications, Computers and Electronics in Agriculture, v. 36, p. 173-191, 2002 


\subsubsection{Processamento das imagens espectrais}

Um destaque particular deve ser dado aos processamentos das imagens espectrais. Em geral os pesquisadores buscam detectar diferenças entre um grupo teste e um controle e a partir das imagens espectrais podem explorar tanto a intensidade do sinal óptico detectado quanto a banda espectral de detecção. Sendo assim, em geral é necessário utilizar processamentos para melhorar as imagens capturadas, caracterizar os objetos das imagens e classificar ou discriminar os objetos da imagem. Processamentos para melhorar as imagens capturadas envolvem a utilização de filtros digitais, equalização de histograma, transformadas de Fourier, convolução, entre outros, com a intenção de maximizar o contraste ou remover o ruído presente na imagem. Processamentos para caracterização dos objetos da imagem buscam detectar formas geométricas, contornos, cores, texturas, intensidades, entre outros. Já os processamentos de classificação (grupo ao qual pertence) ou discriminação (ênfase) são aplicados a cada objeto detectado na imagem e podem ser baseadas em técnicas estatísticas mais simples ou em algoritmos complexos como as redes neurais ou a lógica fuzzy (19).

Com imagens espectrais da refletância as cores (refletância no visível) são particularmente exploradas como ferramenta de classificação. Pydipati, Burks e Lee (2006) utilizaram o método de co-ocorrência das cores para transformar o padrão RGB das imagens para o HSI no intuito de discriminar folhas de plantas cítricas contaminadas com melanose, verrugose e com mancha graxa dos citros (Mycosphaerella citri) de folhas sadias (57). Em outro experimento Blasco, Aleixos e Moltó (2007) desenvolveram um sistema para diagnóstico de defeitos nas cascas de frutas cítricas e seleção dos frutos para o mercado de consumo. Nesse trabalho os autores realizam a segmentação dos defeitos visualizados baseados nas cores dos frutos. $\mathrm{O}$ processamento pode ser aplicado à maioria das variedades de frutas cítricas (9). Já Kleynen, Leemans e Destain (2005) utilizaram não só as cores, mas também a refletância no infravermelho (em $750 \mathrm{~nm}$ e $800 \mathrm{~nm}$ ) pra discriminar e classificar defeitos nas cascas de maçãs através de correlações calculadas em cada pixel da imagem (41).

Outros exemplos, que envolvem técnicas de classificação mais complexas, como a transformações aplicadas aos dados, análise dos componentes principais, método de divergência da informação espectral, modelos de regressão linear e não-linear, entre outras, podem ser encontrados em artigos de revisão sobre imagem computacional na agricultura (19,53,58-59). Os experimentos envolvendo processamento de imagens espectrais da fluorescência emitida 
pelas amostras permanecem tradicionais às técnicas de análise dos espectros, onde os pesquisadores compõem imagens de razões das bandas detectadas e estudam a variação do valor das razões na imagem $(16-17,19,54)$. 


\section{INSTRUMENTAÇÃO E MONTAGEM}

Este capítulo será dedicado à instrumentação utilizada neste trabalho. Inicialmente descreveremos o equipamento utilizado na espectroscopia de fluorescência induzida por LASER (LIF), o qual utiliza um espectrômetro com fibra óptica. Em seguida, descreveremos dois sistemas de imagens de fluorescência baseados em iluminação a LED.

\subsection{ESPECTROSCOPIA DE FLUORESCENCIA INDUZIDA POR LASER}

Os equipamentos para espectroscopia de fluorescência induzida por LASER (LIF) vêm sendo desenvolvidos e aplicados nos últimos vinte anos. Apesar do aperfeiçoamento específico e sua miniaturização, sua configuração básica permanece intacta. Basicamente, os equipamentos são compostos por fonte de luz, elementos difrativos, lentes e fotodetectores (68).

Neste trabalho utilizamos uma unidade portátil comercial (Spectr-Cluster, Cluster Ltd., Rússia). Este é composto por um LASER de estado sólido de $\mathrm{Nd}: \mathrm{YAG}^{+3}$ emitindo $10 \mathrm{~mW}$ de potência óptica em $532 \mathrm{~nm}$ ( $2^{\circ}$ harmônico da emissão fundamental em $\left.1064 \mathrm{~nm}\right)$, um cabo de fibras ópticas multimodo na configuração Y, um monocromador que opera na região espectral entre 350 e $850 \mathrm{~nm}$ com resolução espectral de $1.95 \mathrm{~nm}$ e um laptop para digitalizar e armazenar os dados (8).

A Figura 3.1 mostra um esquema do sistema para LIF. O cabo de fibras ópticas tem o formato em Y para poder guiar a luz de excitação das moléculas e coletar a fluorescência emitida pela amostra. O feixe LASER é guiado através de uma fibra no centro do cabo, e o sinal da fluorescência emitida e da reflexão pela superfície da amostra são coletados por seis fibras periféricas. A luz coletada é guiada ao monocromador, onde atravessa um filtro óptico na configuração passa-altos comprimentos de onda; tal filtro atenua a intensidade da reflexão em mais de $99 \%$ e a intensidade da fluorescência coletada em cerca de 10\%. Em seguida os sinais ópticos incidem sobre uma grade de difração que provoca a dispersão dos sinais. A primeira ordem de difração da grade incide sobre um sensor linear tipo CCD (Charge Coupled Devi$c e$ ), que permite a leitura do espectro em conjunto com um software fornecido pelo fabricante. 


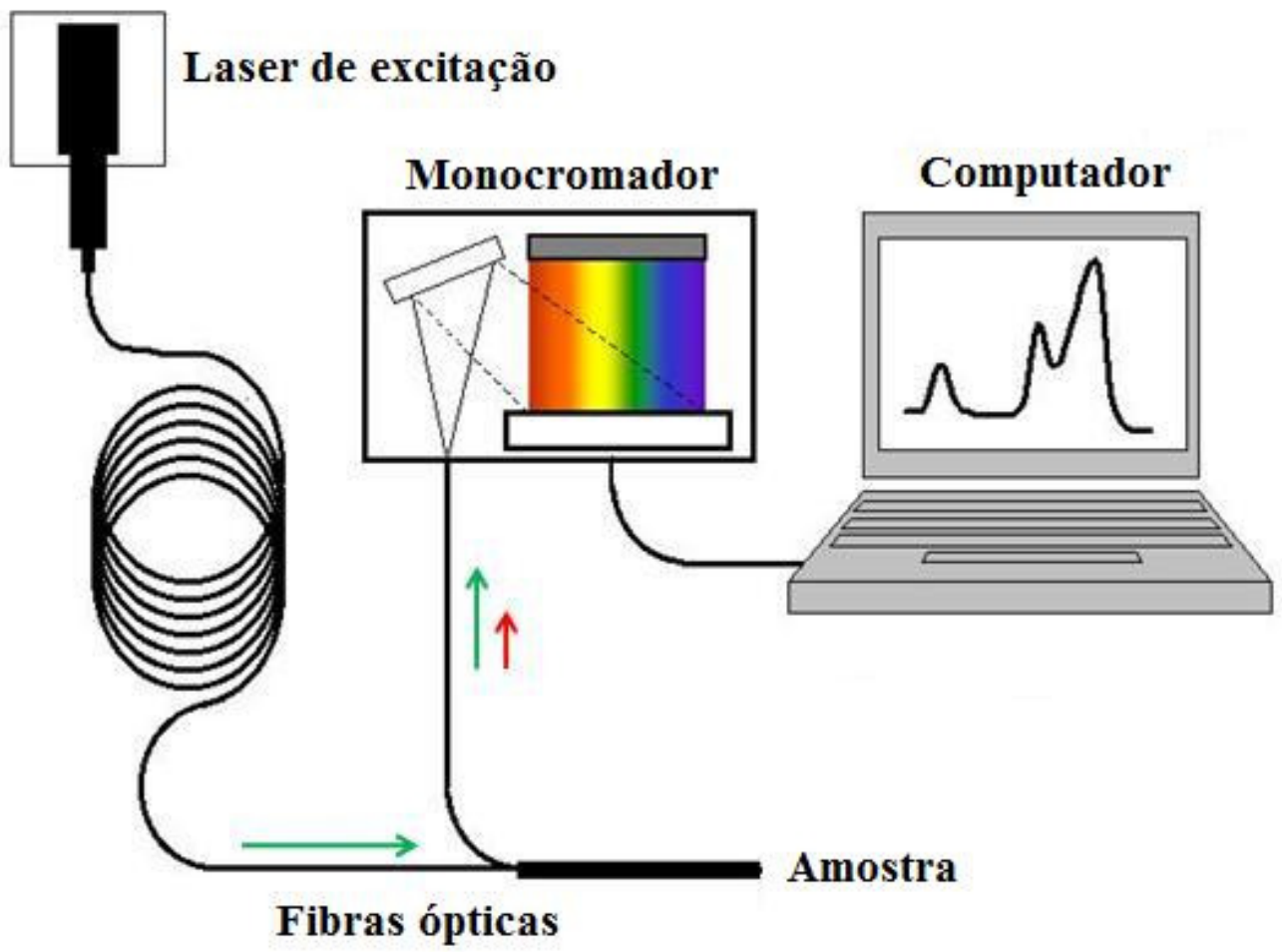

Figura 3.1 - Esquema de funcionamento do espectrômetro destacando o caminho óptico da luz de excitação, da reflexão e da fluorescência, além dos principais componentes: Laser de excitação, cabo de fibras ópticas em Y, monocromador e computador. Dentro do monocromador estão os filtros de atenuação da reflexão, a grade de difração para dispersão do sinal óptico e o sensor linear CCD para detecção da fluorescência e da reflexão.

A principal característica deste espectrômetro é sua portabilidade, pois era possível operá-lo com baterias convencionais. Em geral, o sistema pode operar durante 8 horas com uma bateria de $65 \mathrm{~A} /$ hora. Isto nos permitia levá-lo diretamente ao campo. A Figura 3.2a apresenta uma imagem digital do sistema. Um típico espectro de fluorescência de uma folha é mostrado na figura 3.2b. Podemos identificar três picos característicos: a) O primeiro em 532 nm que é devido à reflexão da luz LASER pela folha; b) O segundo em o terceiro, 685 e 740 nm respectivamente, devido à emissão da clorofila a. Devemos ressaltar que o pico da reflexão é aproximadamente 1000 vezes maior do que os da fluorescência, e que nesta figura ele só apresenta uma amplitude da mesma ordem da fluorescência devido ao filtro óptico contido no sistema. 

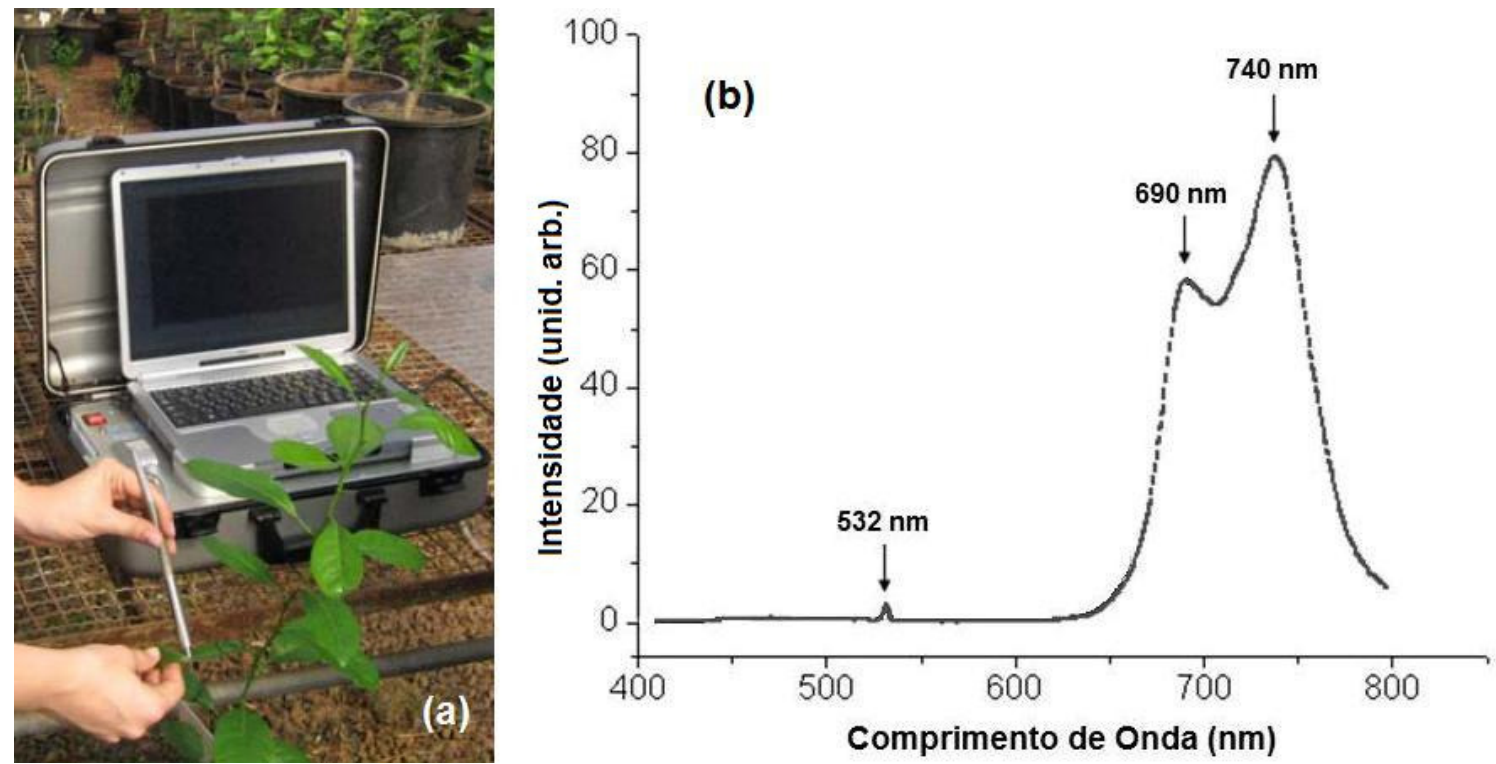

Figura 3.2 - (a) Imagem digital do espectrômetro sendo utilizado para leitura da fluorescência de uma folha. (b) Um típico espectro de fluorescência de uma folha, destacando a reflexão do LASER em 532 nm e os picos de emissão da clorofila em $690 \mathrm{~nm}$ e $740 \mathrm{~nm}$.

\subsection{ESPECTROSCOPIA DE IMAGEM DE FLUORESCÊNCIA}

O sistema da LIF apresenta a desvantagem de analisar uma pequena área da amostra, devido à pequena área da fibra de coleta. Os sistemas para espectroscopia de imagem da fluorescência evitam esse problema, pois combinam a técnica da espectroscopia da fluorescência com a formação de imagens digitais. Essa técnica permite a análise dos sinais ópticos com resolução espacial e espectral ao mesmo tempo, uma vez que forma as imagens escolhendo a banda de radiações que será detectada; cada imagem formada pela detecção em uma banda espectral específica é chamada imagem espectral (68).

Como visto na revisão da literatura (capítulo 2), há duas formas de detectar imagens espectrais, varrendo a banda espectral de detecção ou o campo de visão. Na primeira técnica o elemento que realiza a seleção espectral é o filtro óptico; a seleção pode ser feita eletronicamente, com o uso de filtros sintonizáveis, ou mecanicamente, quando filtros ópticos tradicionais estão associados a rodas de filtros (68). No segundo caso a informação espectral é fornecida por um elemento difrativo, em geral espectrógrafos; devido à redução do seu campo de visão há necessidade de varredura espacial sobre a amostra (27). Nosso trabalho se concentrou no desenvolvimento de sistemas de imagens espectrais baseados em espectrógrafos e roda de filtros. 


\subsubsection{Sistema de imagens espectrais baseado em espectrógrafos}

Neste tópico descreveremos o sistema de imagens espectrais baseado em espectrógrafos (SIE) avaliando os componentes, princípio de funcionamento, procedimento de calibração do SIE e procedimento de composição da imagem espectral.

\subsubsection{Componentes do SIE}

Em linhas gerais, o SIE é composto por um espectrógrafo, uma lente objetiva, uma câmera CCD científica, um computador, um sistema de iluminação para induzir a fluorescência e um scanner para varredura da amostra sob o sistema. O espectrógrafo utilizado no SIE foi um Hyperspec-VNIR® (Headwall Photonics, EUA), que opera na região de 400 a $1.000 \mathrm{~nm}$ com resolução espectral de 1,29 nm. Fendas de 12 e $40 \mu \mathrm{m}$ podem ser utilizadas neste sistema. Obviamente que uma fenda menor gasta mais tempo e recurso computacional na aquisição que a fenda maior, por isso a fenda de $40 \mu \mathrm{m}$ foi utilizada nos experimentos.

Uma câmera CCD monocromática EDC-1000HR ${ }^{\circledR}$ (Electrim Corporation, EUA) foi utilizada para capturar as imagens. Essa câmera possui um sensor de 8,67 $\mathrm{mm} \times 6,59 \mathrm{~mm}$ em uma matriz de $753 \times 244$ pixels e um controle eletrônico de tempo de exposição de 1 a $10^{5}$ ms. A exposição durante longos tempos é necessária para capturar imagens de fluorescência. É importante ressaltar que longos tempos de exposição também aumentavam a intensidade de fundo na CCD, e para compensá-la uma imagem no escuro era capturada e subtraída das imagens experimentais. A lente objetiva utilizada é o modelo \#53-301 (Edmund Optics, EUA) que possui controle manual do foco da imagem e permite uma amplificação do campo de visão em até sete vezes. O padrão de acoplamento óptico dessa lente objetiva é o CS-Mount.

No SIE a iluminação das amostras era fornecida por um sistema composto por nove diodos emissores de luz de alto brilho, divididos em três conjuntos de três diodos emissores. Um conjunto é formado pelos diodos LUXEON III LXHL-PW09 (Philips Lumileds Lighting Co., EUA) que emitem luz branca no padrão de iluminação D55 com $1 \mathrm{~W}$ de potência ótica emitida por diodo. O segundo conjunto é composto pelos diodos ULTRAVIOLET EDIXEON EDEV-3LA1 (Edison Opto Co., Taiwan) os quais emitem luz violeta com pico de emissão em 
$405 \mathrm{~nm}$ e com largura de banda de $20 \mathrm{~nm}$; cada diodo emite aproximadamente $300 \mathrm{~mW}$ de potência ótica. O terceiro conjunto é formado por diodos LUXEON III LXHL-PB09 (Philips Lumileds Lighting Co., EUA) os quais emitem luz azul com pico de emissão em $470 \mathrm{~nm}$ e com largura de banda de $20 \mathrm{~nm}$; assim como no conjunto anterior, cada diodo emite cerca de $300 \mathrm{~mW}$ de potência ótica.

Por serem de alto brilho a dissipação de calor dos diodos deve ser bem eficiente; por esta razão eles foram colados em um suporte metálico o qual serve como dissipador térmico. Este conjunto foi acoplado à lente objetiva, permitindo uma iluminação uniforme em uma área circular com raio de $8 \mathrm{~cm}$.

Para prover energia elétrica para os diodos uma fonte elétrica na configuração fonte de corrente foi desenvolvida. Essa fonte permite o controle da corrente elétrica fornecida a cada um dos diodos. A fonte foi ajustada para prover, no máximo, $3 \mathrm{~V}$ de tensão e $700 \mathrm{~mA}$ de corrente a cada um dos diodos. Esses valores determinam a tensão e a corrente de operação dos diodos no modo típico, quando os diodos apresentam o seu melhor rendimento. Valores acima destes antecipam a falência dos diodos.

O scanner para varredura da amostra é composto por estruturas metálicas de alumínio, uma placa de acrílico, um motor de passo e seu controle eletrônico, rolamentos e uma fonte elétrica. A placa de acrílico foi escolhida para permitir a trans-iluminação das amostras. $\mathrm{O}$ conjunto permite um deslocamento de $25 \mu \mathrm{m}$ na direção de varredura por passo do motor, controlado pelo computador através de uma porta paralela. Dependendo de $\Delta \mathrm{L}$ o computador ajusta o número de passos do motor para que uma imagem contínua de toda amostra seja obtida.

Finalizando, os componentes foram fixados em uma estrutura metálica de alumínio que permite uma estabilidade mecânica para a realização das imagens. Enquanto a Figura 3.3a apresenta uma montagem esquemática do SIE a Figura 3.3b apresenta a imagem digital do sistema depois de montado. 


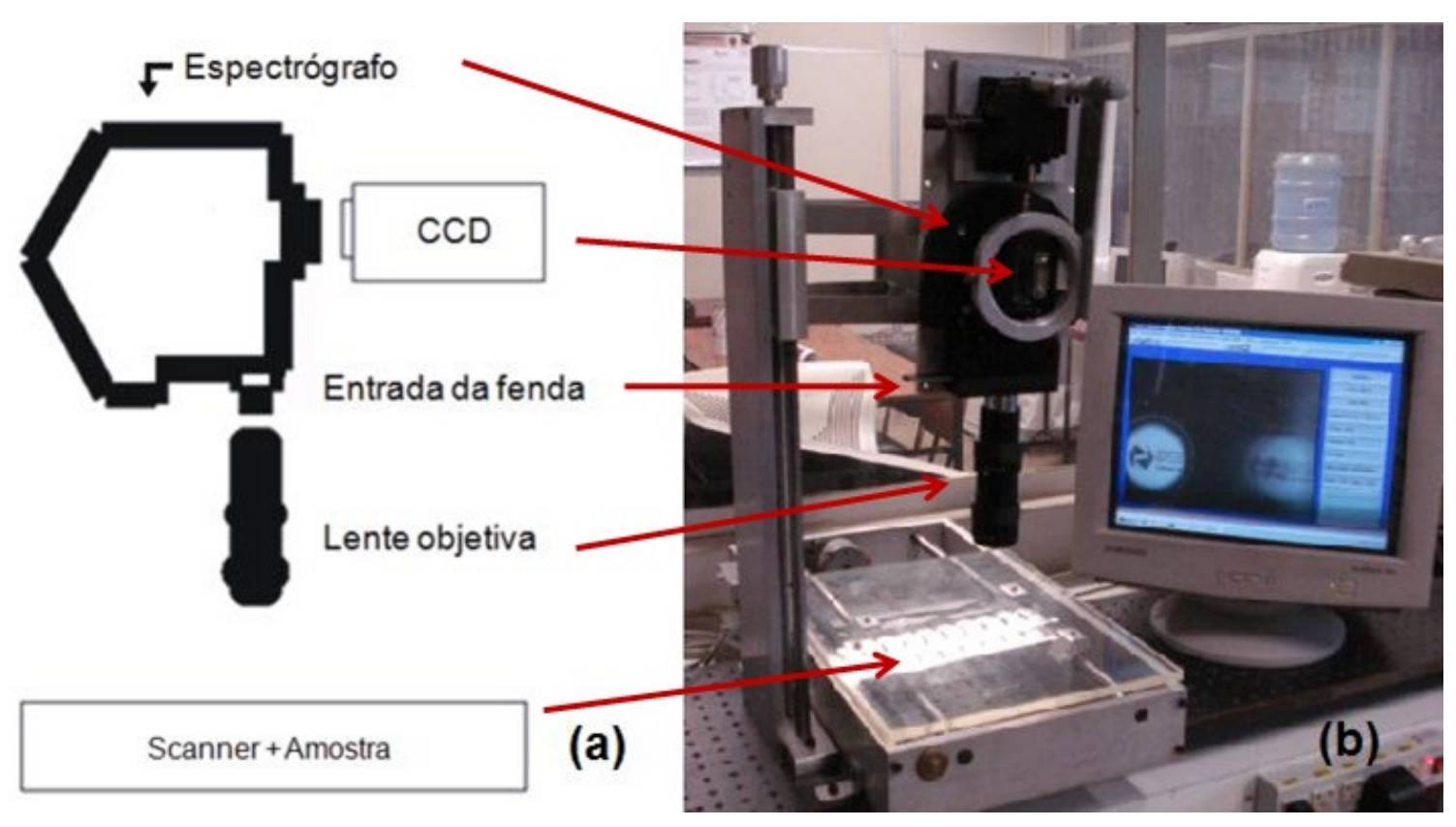

Figura 3.3 - (a) Esquema do SIE mostrando as partes que compõem o sistema e a localização de cada parte. (b) Foto do sistema pronto para uso.

\subsubsection{Principio de funcionamento do SIE}

No SIE o espectrógrafo é o componente principal, pois é onde ocorre a dispersão espectral da imagem. Espectrógrafos são elementos óticos passivos baseados em elementos difrativos que formam uma imagem da dispersão da luz emitida pela amostra em um plano. Uma vez que uma câmera é posicionada neste plano onde a imagem da dispersão é formada, torna-se possível capturar a imagem formada pelo espectrógrafo (27). Devido à própria característica dos elementos difrativos, a dispersão óptica tem um caráter contínuo, o que provoca sobreposição da informação espacial com a espectral da imagem formada. Para evitar a sobreposição uma fenda de algumas dezenas de micrômetros deve ser utilizada antes do espectrógrafo. Isso evita a superposição, porém reduz o campo de visão do sistema, o que implica a necessidade de varrer a amostra sob o sistema, caso a região de interesse na amostra seja maior que o campo de visão observado.

A Figura 3.4 é um exemplo típico de uma imagem do espectrógrafo obtida com uma fenda de $40 \mu \mathrm{m}$. Neste exemplo, uma folha de papel branca A4 foi utilizada como amostra; para a aquisição da imagem a folha de papel foi iluminada por uma lâmpada de mercúrio de $10 \mathrm{~mW}$ de potência e o tempo de integração da câmera foi de $10 \mathrm{~ms}$. Na imagem é possível 
identificar a ordem zero e a primeira ordem da difração do espectrógrafo. Outras ordens da difração não são detectadas devido à limitação do tamanho do sensor da câmera. Na primeira ordem de difração são observadas regiões bem definidas numeradas de 1 a 4 . Enquanto as regiões 1 e 3 são referentes às linhas de emissão da lâmpada em 435 nm e 546 nm, as regiões 2 e 4 são referentes à fluorescência emitida pelo papel. Apesar da detecção, nenhuma outra linha de emissão da lâmpada é observada devido ao baixo tempo de integração da câmera.

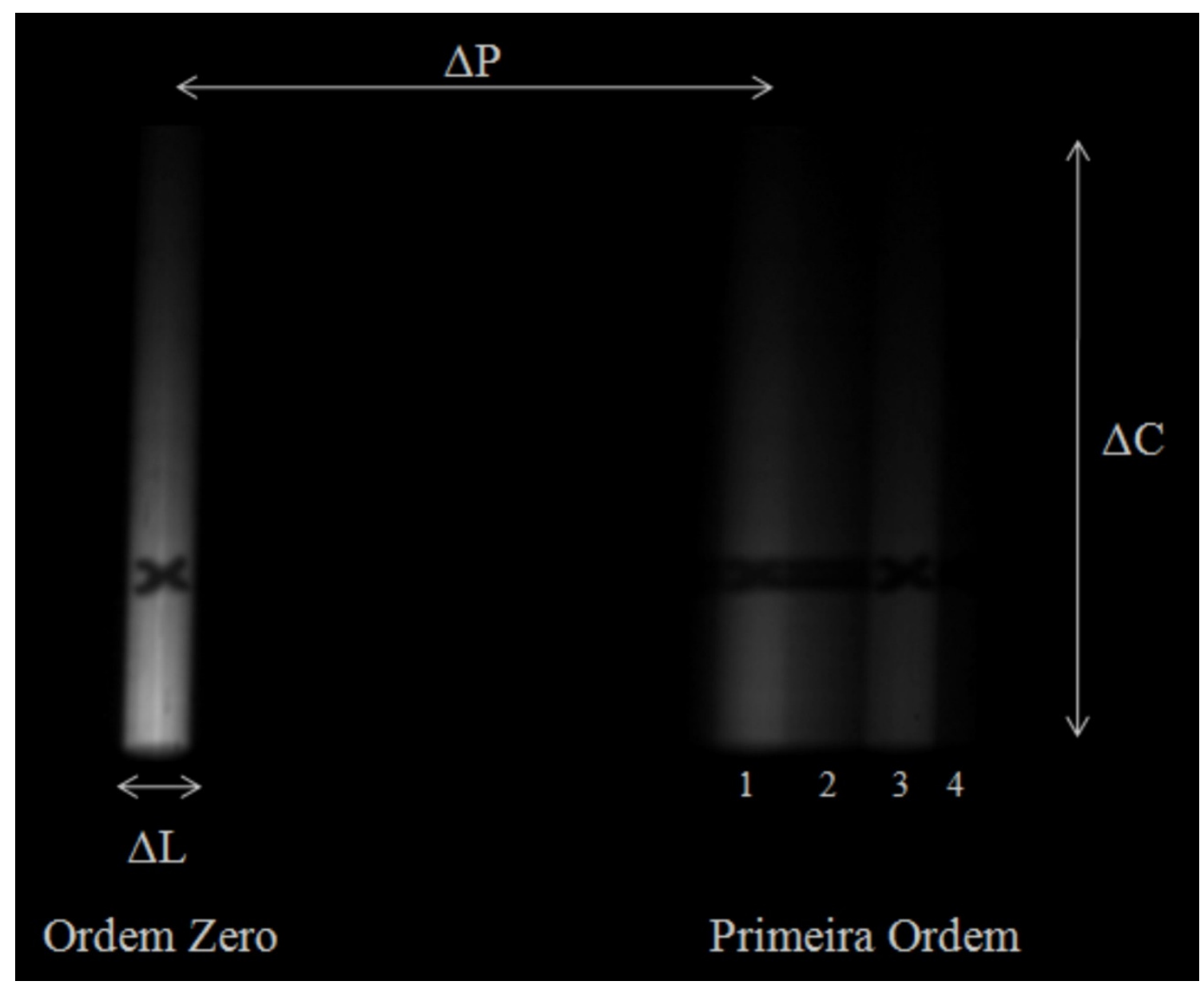

Figura 3.4 - Exemplo de imagem formada no espectrógrafo. Ela revela a ordem zero e a primeira ordem de difração e outros parâmetros da calibração do SIE. Neste exemplo uma folha de papel branco foi iluminada por uma lâmpada de mercúrio. Regiões 1 e 3: reflexão das linhas emitidas pela lâmpada de mercúrio em $435 \mathrm{~nm}$ e $536 \mathrm{~nm}$. Regiões 2 e 4: fluorescência emitida pelo papel. Na calibração desta imagem $\Delta \mathrm{L}=\mathbf{2} \mathrm{mm}$ e $\Delta \mathrm{C}=\mathbf{4 0} \mathrm{mm}$.

Este exemplo também nos permite identificar outros parâmetros importantes da imagem do espectrógrafo. A largura da imagem observada $(\Delta \mathrm{L})$ depende da abertura da fenda e do sistema de lentes utilizado. A distância entre a ordem zero de difração e um comprimento de onda da primeira ordem $(\Delta \mathrm{P})$ esta associada com a difração do espectrógrafo, sendo um 
parâmetro intrínseco que será calibrado. Outro parâmetro importante é o campo de visão $(\Delta \mathrm{C})$ que determina a região da amostra que será observada, e está diretamente associada à distância da amostra até o sistema e à capacidade da lente de ampliar a imagem. Este parâmetro também requeria calibração.

\subsubsection{Calibração do SIE}

O desempenho do SIE depende de vários parâmetros, como já foi mencionado. Estes parâmetros dependem do sistema de lentes, do espectrógrafo e da câmera CCD. Isso leva à necessidade de calibrar o SIE com os componentes que estão sendo utilizados para a formação da imagem espectral. Esta calibração se subdivide em duas, uma espacial e outra espectral. A calibração espacial foi realizada medindo a largura da imagem $(\Delta \mathrm{L})$ e o campo de visão do SIE $(\Delta \mathrm{C})$ em função da distância entre o sistema de lentes e a amostra experimental. O resultado da calibração espacial é apresentado nas Figuras 3.5a e 3.5b. Como se pode observar, ambos os parâmetros apresentam um comportamento linear.
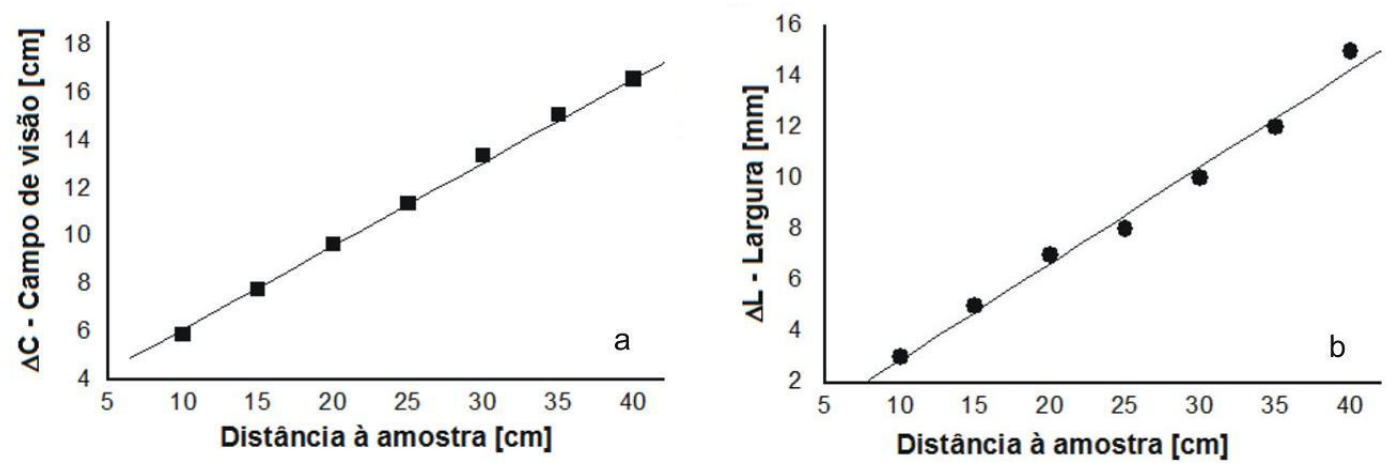

Figura 3.5 - Calibração espacial do SIH. (a) Variação do campo de visão do sistema ( $\Delta$ C) em função da distância entre o sistema de lentes e a amostra. (b) Variação da largura $(\Delta \mathrm{L})$ em função da distância entre o sistema de lentes e a amostra. Ambos apresentam um comportamento linear.

Outro parâmetro necessário para a análise das imagens capturadas pelo SIE é a resolução espacial da imagem. Este dado informa ao usuário o tamanho do grão detectado por cada pixel da imagem e pode ser calculado pela razão entre $\Delta \mathrm{C}$ e o número de pixels da imagem na dimensão equivalente ao campo de visão. Como esse parâmetro depende do número de pixels e da dimensão física do sensor da câmera, além das características do 
espectrógrafo, a resolução espacial também é exclusiva da montagem desenvolvida. A Figura 3.6 mostra o comportamento linear da resolução espacial do SIE em função da distância entre o sistema de lentes e a amostra experimental. Esse comportamento linear era esperado uma vez que $\Delta \mathrm{C}$ também varia linearmente com a distância entre o SIE e a amostra.

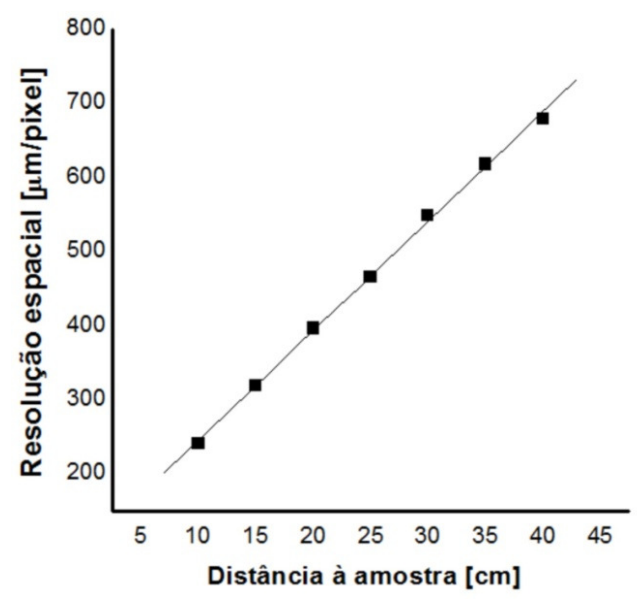

Figura 3.6 - Resolução espacial do SIE para a montagem desenvolvida em função da distância entre o sistema de lentes e a amostra. Relação linear já esperada devido ao comportamento do parâmetro $\Delta C$.

$\mathrm{Na}$ calibração espectral foi medida a distância $\Delta \mathrm{P}$ (em números de pixels) entre a imagem da ordem zero de difração e a imagem de um comprimento de onda na primeira ordem de difração. O resultado é apresentado na Figura 3.7 e mostra a relação linear entre $\Delta \mathrm{P}$ e os comprimentos de onda da $1^{\mathrm{a}}$ ordem. Para obter esse resultado foram utilizados quatro sistemas LASER. Um de gás de He-Cd emitindo em $442 \mathrm{~nm}$, um de estado sólido de $\mathrm{Nd}: \mathrm{YAG}^{+3}$ dobrado emitindo em $532 \mathrm{~nm}$ e dois de diodo emitindo em $660 \mathrm{~nm}$ e $780 \mathrm{~nm}$.

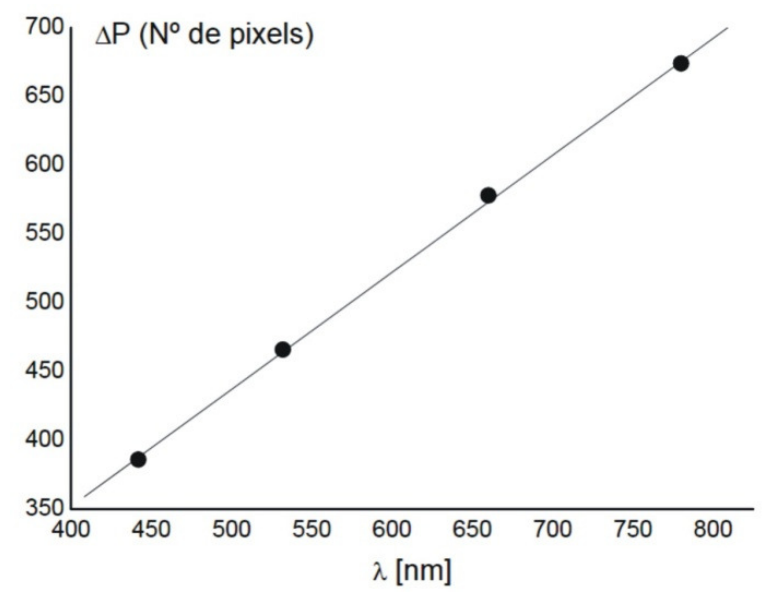

Figura 3.7 - Gráfico da calibração espectral do SIE mostrando a relação linear entre o parâmetro $\Delta \mathrm{P}$ e os comprimentos de onda da primeira ordem de difração de uma imagem. 
Uma informação adicional é a resolução espectral do sistema, que é diferente da resolução espectral do espectrógrafo. Enquanto a resolução espectral do espectrógrafo informa a separação de dois comprimentos de onda dispersados pelas grades de difração contidas nele, a resolução do sistema informa a largura espectral da banda que pode ser formada imagens sem que haja sobreposição da informação espacial com a espectral. Esse dado é obtido ao medir o número de pixels contido em $\Delta \mathrm{L}$ e aplicar esse valor na curva de ajuste da calibração espectral $(\Delta \mathrm{P})$. O resultado mostra que a resolução espectral do sistema é de aproximadamente $20 \mathrm{~nm}$.

\subsubsection{Composição da imagem espectral}

Após a captura das imagens do espectrógrafo sobre toda a região de interesse na superfície da amostra, o próximo passo é a composição das imagens espectrais em diferentes comprimentos de onda. Esta tarefa é puramente computacional e para isso foi desenvolvida uma rotina computacional no Matlab ${ }^{\circledR}$ (The MathWorks, EUA). A rotina utiliza os parâmetros da calibração espacial e espectral do SIE para compor as imagens e permite ao usuário a livre escolha da banda espectral em que será formada a imagem. A tarefa da rotina computacional é organizar as imagens do espectrógrafo em sequiência, selecionar o conjunto de pixels referentes à banda desejada em cada uma das imagens capturadas e construir uma imagem espectral concatenando as regiões selecionadas.

Uma dificuldade encontrada na formação das imagens espectrais é o efeito das bordas da fenda de $40 \mu \mathrm{m}$ ao concatenar as regiões selecionadas. Devido ao perfil da fenda, as variações de intensidades detectadas nas regiões mais próximas da borda não dependem unicamente das características da amostra. Para diminuir esse efeito apenas a região central foi selecionada para a concatenação, conseqüentemente, o passo de varredura do scanner teve de ser reduzido para que a imagem espectral formada fosse espacialmente semelhante à amostra.

A Figura 3.8 apresenta o exemplo de uma imagem espectral típica obtida pelo SIE. Neste exemplo uma folha contaminada com CVC foi utilizada para formação de imagens espectrais da fluorescência emitida em 690 nm (Figura 3.8b) e em 740 nm (Figura 3.8c). A 
Figura 3.8a é a imagem digital da amostra utilizando luz branca como iluminação e revela os sintomas visuais, perceptíveis a olho nu, sobre a superfície da amostra. Já as imagens espectrais revelam a fluorescência emitida com informação espacial e espectral.
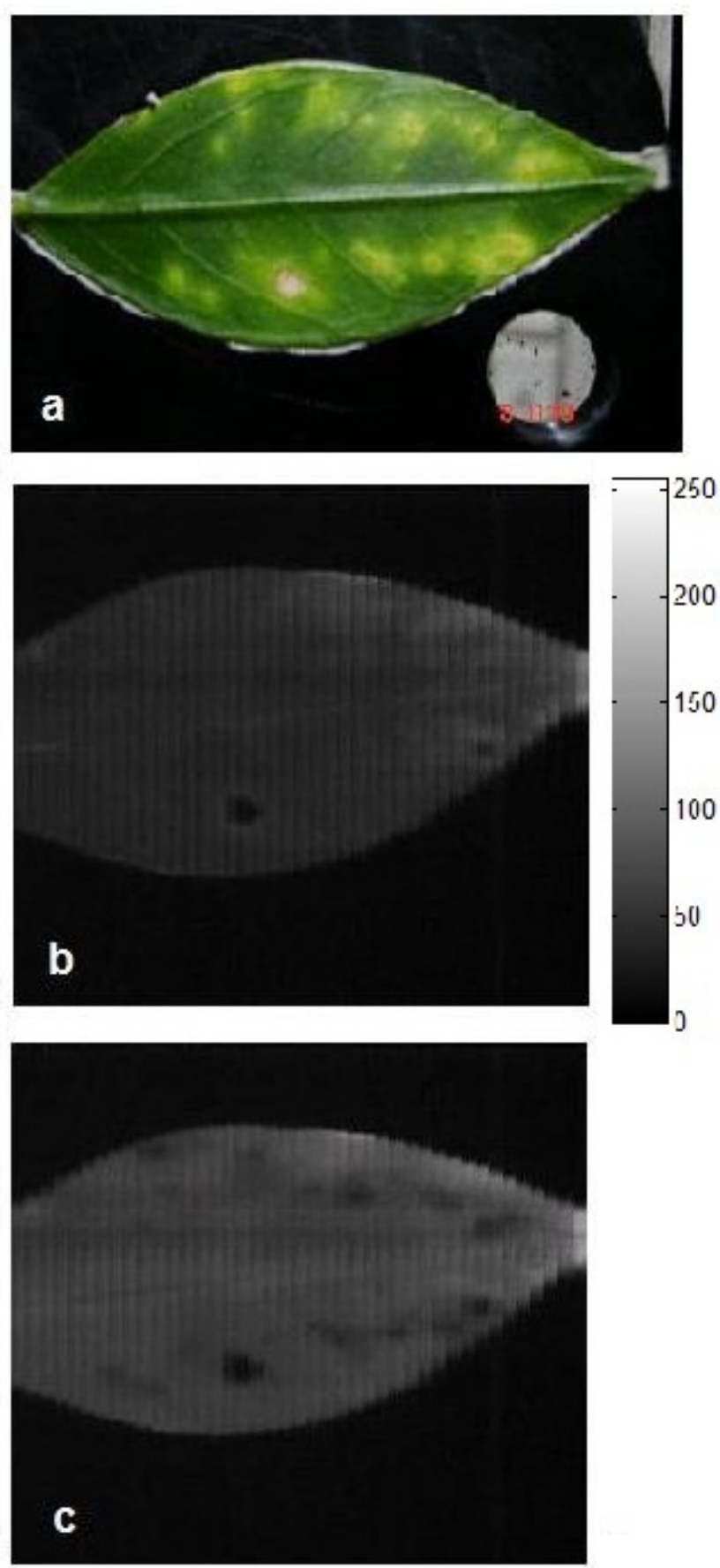

Figura 3.8 - Exemplo de imagens espectrais capturadas pelo SIE utilizando $25 \mathrm{~mW} / \mathrm{cm}^{2}$ de luz azul em 470 nm para iluminação. (a) Imagem digital de uma folha com CVC apresentando os sintomas visuais da doença. (b) Imagem espectral da fluorescência emitida em $690 \mathrm{~nm}$ revelando a informação espectral e espacial. (c) $O$ mesmo tipo de informação presente em (b), sendo $740 \mathrm{~nm}$ o comprimento de onda de emissão da fluorescência. 
Este exemplo foi realizado em uma sala escura com iluminação por luz azul em 470 $\mathrm{nm}$, provendo cerca de $25 \mathrm{~mW} / \mathrm{cm}^{2}$ sobre a amostra. Para a captura da imagem de cada fenda foi necessário 20 segundos de exposição da $\mathrm{CCD}$, o que resultou um tempo total de 25 minutos para captura das imagens do espectrógrafo. As imagens espectrais foram compostas em seguida, e o tempo de processamento para compor cada imagem espectral é inferior a 10 segundos. Apesar do processamento das imagens é possível ver a influência da fenda no resultado final das imagens espectrais.

\subsubsection{Sistema de imagens espectrais baseado em filtros ópticos}

Os resultados obtidos com o SIE foram satisfatórios, porém esse sistema ainda apresentava a limitação de ser um equipamento para uso exclusivo no laboratório. Por isso, foi necessário desenvolver um novo sistema de imagens espectrais que pudesse ser transportado do laboratório para as fazendas. Neste segundo sistema de imagens, optou-se pelo desenvolvimento de um equipamento com uma roda de filtros no lugar do espectrógrafo devido à necessidade de um sistema robusto e que pudesse ser utilizado no campo. Uma vez que, a partir dos dados do espectrógrafo, foram escolhidas as melhores bandas espectrais para formação das imagens, bastava compor um sistema de imagens espectrais com filtros ópticos (SIF) com bandas passantes nas mesmas regiões espectrais que foram escolhidas. Além disso, um sistema baseado em uma roda mecânica com filtros ópticos passa-banda é mais rápido e mais robusto que o SIE, além de não necessitar calibração e composição das imagens espectrais. Na seqüência descreveremos os componentes do SIF e o procedimento de aquisição das imagens.

\subsubsection{Componentes do SIF}

A composição do SIF é semelhante à do SIE, pois o princípio permaneceu o mesmo: induzir a fluorescência das amostras e capturar imagens em bandas específicas. O SIF é composto por uma câmera CCD científica, um sistema de lentes, uma roda de filtros com oito

posições, quatro filtros ópticos passa-banda, um sistema de iluminação das amostras, um 
laptop e uma estrutura metálica para comportar e alinhar os componentes e as amostras.

A câmera utilizada foi uma mvBlueFOX120a (Matrix Vision, Alemanha). Ela possui um sensor de $4,73 \mathrm{~mm} \times 3,55 \mathrm{~mm}$ em uma matriz de $640 \times 480$ pixels e um controle eletrônico da exposição do sensor de 1 a $10^{7} \mu$ s. Ela forma imagens monocromáticas com 8 , 10 ou 12 bits por pixel. Além disso, essa câmera se comunica com computadores via barramento USB e possui drives de captura para o ambiente Labview ${ }^{\circledR}$.

No SIF a lente objetiva foi a mesma utilizada no SIE, pois o padrão de acoplamento óptico era o mesmo e a lente objetiva possuía controle do aumento e do foco da imagem. A roda de filtros utilizada foi o modelo CFW-1-8 (Finger Lakes Instrumentation, EUA) que comporta até oito filtros ópticos. A roda de filtros era controlada por computador através de um software fornecido pelo fabricante e se comunica com o mesmo via barramento USB.

Os filtros ópticos foram escolhidos baseados nos comprimentos de onda escolhidos para formação das imagens espectrais. A partir das imagens do SIE foram escolhidos os comprimentos de onda $610 \mathrm{~nm}, 690 \mathrm{~nm}$ e $740 \mathrm{~nm}$. Além desses, o comprimento de onda em $570 \mathrm{~nm}$ foi adicionado, pois a fluorescência nessa região não dependia do conteúdo de clorofila na amostra. Sendo assim, quatro filtros ópticos passa-banda foram utilizados no sistema. Os modelos escolhidos foram: FB570-10, FB610-10, FB690-10 e FB740-10 (Thorlabs, EUA). A Tabela 3.1 apresenta as principais características ópticas dos filtros fornecidas pelo fabricante.

Tabela 3.1 - Características ópticas dos filtros passa-banda utilizados no SIF.

\begin{tabular}{ccccc}
\hline Código & $\begin{array}{c}\text { Comprimento } \\
\text { de Onda } \\
\text { Central }\end{array}$ & $\begin{array}{c}\text { Largura da } \\
\text { Banda }\end{array}$ & $\begin{array}{c}\text { Transmitância } \\
\text { Dentro da Banda }\end{array}$ & $\begin{array}{c}\text { Transmitância } \\
\text { Fora da banda }\end{array}$ \\
\hline FB570-10 & $570 \mathrm{~nm}$ & $10 \mathrm{~nm}$ & Entre 48\% e 53\% & $<0.01 \%$ \\
\hline FB610-10 & $610 \mathrm{~nm}$ & $10 \mathrm{~nm}$ & Entre 50\% e 55\% & $<0.01 \%$ \\
\hline FB690-10 & $690 \mathrm{~nm}$ & $10 \mathrm{~nm}$ & $59 \%$ & $<0.01 \%$ \\
\hline FB740-10 & $740 \mathrm{~nm}$ & $10 \mathrm{~nm}$ & Entre 45\% e 51\% & $<0.01 \%$ \\
\hline
\end{tabular}

Fonte: THORLABS. Disponível em: <www.thorlabs.com>. Acesso em 19 de janeiro de 2009.

O sistema de iluminação do SIF é semelhante ao do SIE, porém utiliza apenas seis diodos divididos em dois conjuntos. Um conjunto é formado pelos diodos emissores de luz violeta utilizados no SIE (pico de emissão em $405 \mathrm{~nm}$, largura de banda de $20 \mathrm{~nm}, 300 \mathrm{~mW}$ 
de potência ótica por diodo) e o outro conjunto é composto por diodos emissores de luz azul também utilizado no SIE (pico de emissão em $470 \mathrm{~nm}$, largura de banda de $20 \mathrm{~nm}$ e $300 \mathrm{~mW}$ de potência ótica por diodo). Todos os diodos foram fixados a um suporte metálico e uma fonte elétrica foi confeccionada para prover $3 \mathrm{~V}$ e $700 \mathrm{~mA}$ para cada um dos diodos.

Finalizando, uma estrutura metálica com o formato de uma caixa preta escura foi confeccionada para alinhar os componentes e posicionar as amostras para formação das imagens espectrais. A estrutura foi projetada com a intenção de evitar o ruído óptico causado pela luz externa. Um esquema do SIF é apresentado na Figura 3.9a e uma foto na Figura 3.9b. A câmera e a lente objetiva foram posicionadas fora do suporte metálico, dessa forma era possível ajustar a posição da câmera bem como o aumento e o foco da imagem espectral Tanto a roda de filtros quanto o sistema de iluminação e o suporte da amostra permaneciam na parte interna da caixa. Uma vez posicionada a amostra a caixa era fechada e o processo de captura era iniciado. O sistema também operava com baterias convencionais.
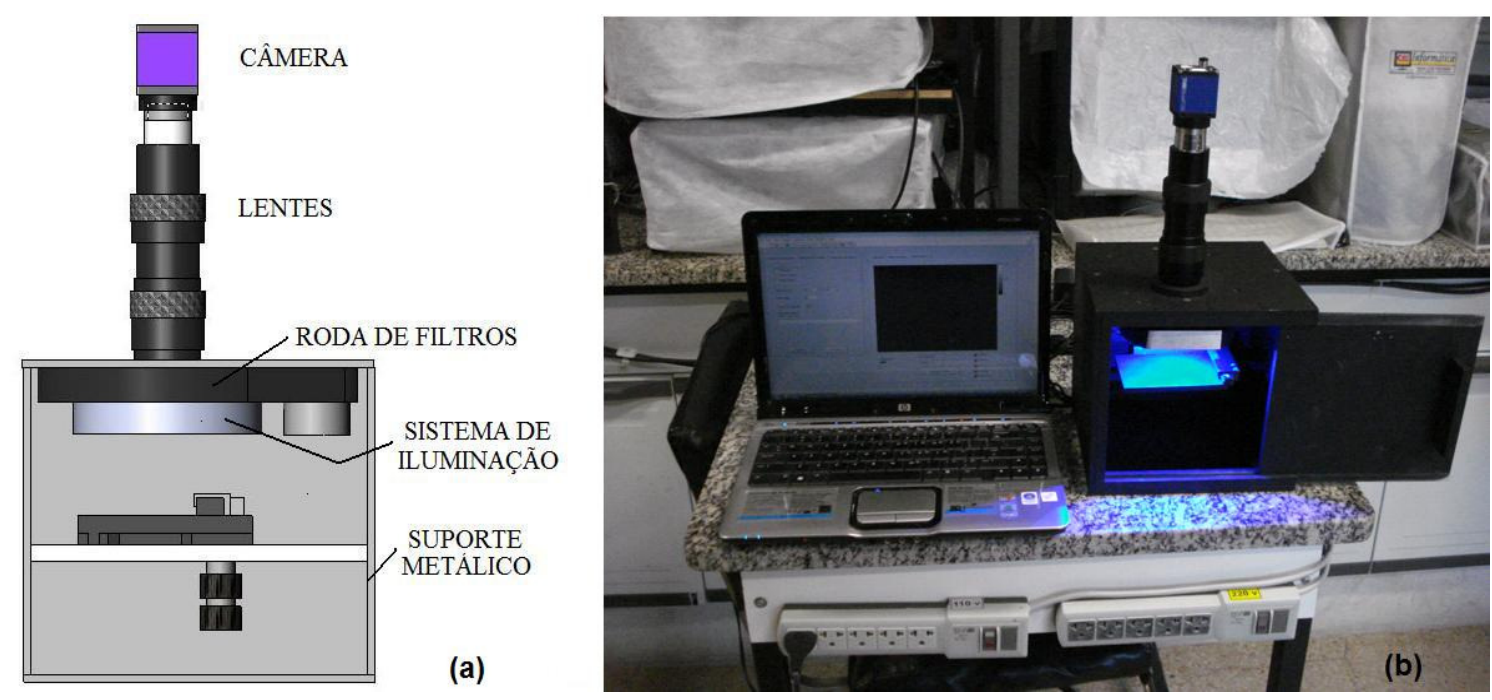

Figura 3.9 - (a) Esquema da montagem do SIF, destacando o alinhamento óptico dos principais componentes como câmera, lentes roda de filtros e sistema de iluminação. (b) Imagem digital do sistema pronto para uso.

\subsubsection{Aquisição das imagens espectrais do SIF}

Uma rotina computacional foi desenvolvida no ambiente Labview ${ }^{\circledR}$ (National Instruments, EUA) para controlar o SIF, capturar e armazenar as imagens espectrais. Essa rotina controlava os parâmetros da câmera de ganho do sinal detectado e tempo de exposição do 
sensor. Além disso, a rotina ativa a captura das imagens por parte da câmera e fica responsável pela visualização e pelo armazenamento da imagem espectral no formato Bitmap.

A rotina computacional também desenvolvia um papel de pré-processamento das imagens espectrais capturadas. Sua função era corrigir a intensidade do sinal detectado tomando como base a resposta espectral do sensor da câmera e a transmissão óptica do filtro passabanda. Cada componente óptico tem uma resposta espectral específica devido aos seus materiais de composição e à sua configuração, essa resposta espectral interfere na detecção e compromete o processamento e a análise dos resultados. Para corrigir esse problema e padronizar a detecção de cada uma das imagens espectrais foi proposto um índice de correção $\operatorname{IC}(\lambda)$ das imagens espectrais, onde:

$$
\operatorname{IC}(\lambda)=T(\lambda) \times S(\lambda)
$$

Na equação 3.1, $\lambda$ é o comprimento de onda que determina a imagem espectral, $\mathrm{T}(\lambda)$ é a porcentagem de transmissão do filtro óptico passa-banda no comprimento de onda central $\lambda$ e $S(\lambda)$ é a sensibilidade espectral relativa do sensor CCD em $\lambda$.

Outro fato relevante é que o ganho de detecção da câmera deveria ser o mesmo em todas as imagens espectrais de uma mesma amostra; dessa forma a razão entre duas das imagens espectrais excluiria a informação do ganho e assim seria possível comparar os resultados de amostras que utilizaram ganhos diferentes durante a captura das imagens espectrais. Sendo assim, o ganho da câmera foi escolhido para captura de uma imagem espectral tomada como referência, e para as demais imagens espectrais o mesmo ganho foi usado. A imagem em 690 nm foi tomada com referência, pois é comum que nesta região espectral ocorra a emissão máxima de fluorescência por parte da clorofila a (17). Por isso, cada um dos índices $I C$ das imagens foi normalizado por IC(690 nm). Com isso o ganho escolhido determinaria a imagem referência $(690 \mathrm{~nm})$ e as demais imagens eram corrigidas pelo seu índice normalizado. Esse procedimento evitava que imagens saturadas ou com baixíssimo sinal fossem capturadas.

A Figura 3.10 mostra um exemplo de imagens espectrais capturadas pelo SIF. Neste exemplo a amostra está contaminada com cancro cítrico e apresenta sintomas visuais, os quais são destacados na imagem digital da amostra (Figura 3.10a). As Figuras 3.10b e 3.10c apresentam as imagens espectrais da fluorescência emitida pela amostra nos comprimentos de onda $690 \mathrm{~nm}$ e $740 \mathrm{~nm}$, respectivamente. Tais imagens mostram a região de interesse destacada na Figura 3.10a e revelam a clareza das imagens espectrais formadas pelo SIF em comparação com as imagens espectrais do SIE. Neste exemplo foi utilizada iluminação por luz 
azul em $470 \mathrm{~nm}$, provendo cerca de $25 \mathrm{~mW} / \mathrm{cm}^{2}$ sobre a amostra. Para a captura da imagem foi necessário 10 segundos de exposição da CCD e uma ganho da câmera de $10 \mathrm{~dB}$.
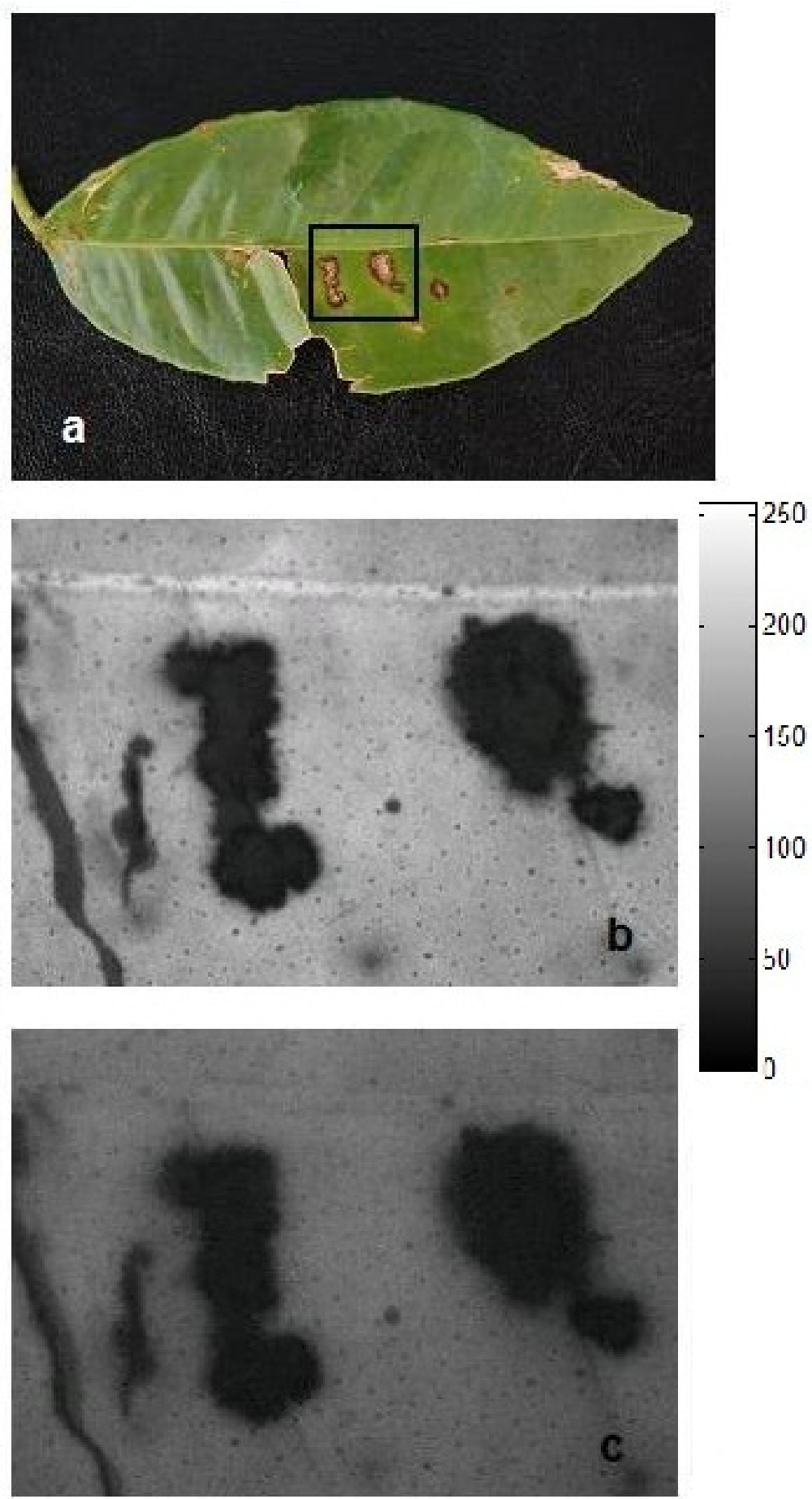

Figura 3.10 - Exemplo de imagens espectrais capturadas pelo SIF utilizando $25 \mathrm{~mW} / \mathrm{cm}^{2}$ de luz azul em $470 \mathrm{~nm}$ para iluminação. (a) Imagem digital de uma folha com cancro cítrico apresentando os sintomas visuais da doença. (b) e (c) Imagens espectrais da fluorescência emitida pela amostra em $690 \mathrm{~nm}$ e $740 \mathrm{~nm}$, respectivamente, revelando a informação espectral e espacial da região de interesse selecionada. 


\section{ESPECTROSCOPIA DA FLUORESCENCIA INDUZIDA POR LASER}

Neste capítulo apresentaremos os experimentos de espectroscopia de fluorescência induzida por LASER (LIF) aplicada no diagnóstico do cancro cítrico usando o espectrômetro com fibra. Inicialmente discutiremos o experimento preliminar onde as folhas doentes foram submetidas à LIF no laboratório do IFSC. Em seguida, apresentamos o experimento de LIF realizado no campo.

\subsection{ESPECTROSCOPIA A FIBRA NO LABORATÓRIO DO IFSC}

Neste experimento nossa intenção era discriminar o comportamento espectral das folhas de plantas infectadas com cancro cítrico das folhas de plantas sadias. E em seguida os dados das amostras com cancro foram comparados com os de amostras com CVC, pois o CVC apresenta sintomas visuais semelhantes ao do cancro.

\subsubsection{Metodologia}

Nestes experimentos foi utilizado o espectrômetro de fluorescência a fibra e as medidas foram realizadas nas dependências do IFSC. As amostras foram coletadas no campo pelos inspetores do FUNDECITRUS e transportadas ao IFSC para realização da LIF. Um total de 500 folhas contaminadas com cancro cítrico e 500 folhas de plantas sadias foram coletadas. $\mathrm{O}$ número de amostras com CVC foi menor 100 unidades. As variedades cítricas estudadas foram: Limão Cravo, Limão Galego, Laranja Pêra, Laranja Valência e Tangerina Ponkan.

As amostras eram trazidas ao IFSC em sacos plásticos e o tempo de transporte do campo ao laboratório variou entre 2 horas e 6 horas de acordo com a distância entre a fazenda e o IFSC. Por isso, optou-se por coleta nas fazendas da vizinhança de São Carlos, onde a distância não fosse maior que $200 \mathrm{~km}$. Quando, por algum impedimento, as amostras não pudes- 
sem ser trazidas ao laboratório no mesmo dia, elas eram mantidas refrigeradas durante o pernoite e transportadas em caixas de isopor durante a viagem.

Aqui devemos enfatizar que durante a coleta das folhas desconsideramos variáveis como as condições do plantio (número e tamanho das plantas, práticas agrícolas, etc.) ou as condições ambientais (clima, condições pluviométricas, nível de água e nutrientes do solo, etc.). Essas variáveis foram desconsideradas, pois nosso objetivo era propor uma técnica tão eficiente quanto as técnicas tradicionais de laboratório, como o isolamento das bactérias e o PCR (31), que são insensíveis às tais propriedades. Depois da leitura da fluorescência as amostras eram transportadas a laboratórios credenciados pela Secretaria de Agricultura do Estado de São Paulo para o diagnóstico oficial da doença cítrica por métodos tradicionais de isolamento das bactérias e PCR. Esse dado foi usado como padrão-ouro para o diagnóstico do cancro e excluía as amostras que apresentassem um diagnóstico diferente do esperado.

Nestes experimentos as folhas eram a entidade determinante do diagnóstico do cancro cítrico, por isso foram coletados dez espectros de cada uma das folhas e um espectro médio foi obtido a partir dos espectros individuais. As leituras da fluorescência foram realizadas mantendo a fibra de coleta a $2 \mathrm{~mm}$ de distância sobre a folha com a intenção de evitar o contato direto e qualquer efeito térmico. Mesmo assim, foram realizadas algumas leituras da fluorescência com diferentes intensidades sobre a amostra e os resultados mostraram não haver variação da intensidade de fluorescência emitida com a intensidade utilizada nos experimentos, revelando não haver qualquer dano por efeito térmico no local de incidência da excitação.

Eventualmente, as lesões de cancro cítrico em folhas possuem duas regiões distintas. Em uma delas há formação de necroses, na outra região o tecido apresenta sintomas de infecção, mas não apresenta necrose, e usualmente essa região apresenta uma cor amarelada. As folhas infectadas ainda apresentam uma região sem sintomas; essa região possui aparência visual idêntica ao tecido sadio (31). A Figura 4.1 mostra uma imagem digital de duas lesões de cancro cítrico em uma folha de laranjeira, destacando as regiões descritas antes.

Em nossos experimentos a fibra de coleta tinha uma área de aproximadamente $1 \mathrm{~mm}^{2}$ e era posicionada na região amarelada das lesões nas amostras contaminadas com o cancro e com a CVC; de fato, só as amostras que apresentavam região amarelada foram escolhidas para o experimento. Nas amostras sadias, o padrão adotado foi manter a fibra de coleta a 3 $\mathrm{mm}$ da veia central da folha. 


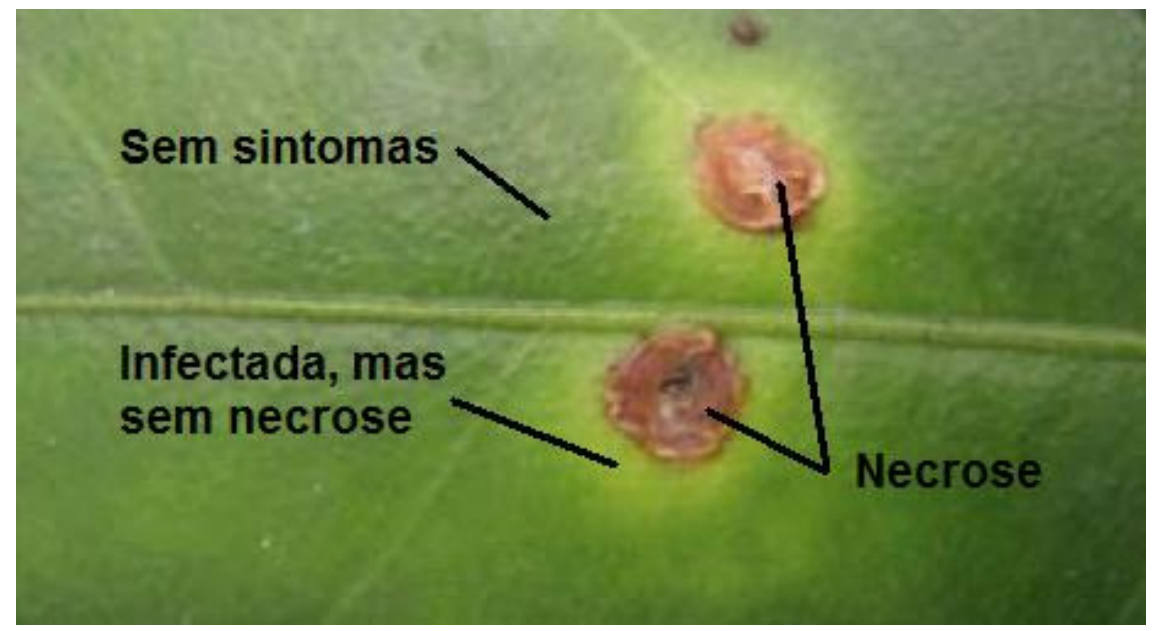

Figura 4.1 - Fotografia digital de duas lesões de cancro cítrico em uma folha de laranjeira. Destaque para a região necrótica e a região além da necrose que ainda apresenta sintoma da infecção. Nesta região de infecção sem necrose foram realizadas as leituras do espectro da fluorescência. Além dessa, a imagem ainda mostra haver uma região onde não há presença de sintomas, e o aspecto visual é idêntico ao dos tecidos das folhas sadias.

\subsubsection{Análise dos Espectros}

\subsubsection{Pré-processamento dos espectros}

Em geral os espectros coletados por espectrômetros apresentam ruídos oriundos do próprio sistema ou do meio ambiente. Os ruídos intrínsecos do próprio espectrômetro estão relacionados com a detecção imprópria do sensor linear $\mathrm{CCD}$, enquanto o ruído do meio ambiente se refere à luz provinda do ambiente e detectada como fluorescência, sem o ser.

O principal ruído oriundo do próprio sensor CCD é a geração de corrente causada por variação na sua temperatura de operação. Neste caso, o aumento da temperatura no sensor facilita a formação de pares elétron-buraco mesmo sem haver a presença de fótons (55). Essa corrente é determinada como um ruído eletrônico e implica erro no dado coletado. O ruído é recorrente em equipamentos com ineficientes ou nenhum sistema de refrigeração do sensor, e quando estes equipamentos são utilizados na detecção de pequenos sinais ópticos a razão sinal-ruído das medidas fica insatisfatória. O ruído eletrônico não possui relações espectrais com o sinal detectado. Como todos os elementos (pixels) de um sensor CCD estão submetidos 
à geração de ruído é comum que este seja observado em todo espectro detectado, simultaneamente.

O ruído óptico do meio ambiente é característico da luz de fundo que acompanha a medida. Sempre que ela é feita em lugares iluminados uma pequena parcela da luz do ambiente pode ser acoplada à fibra de detecção e ser coletada na forma de ruído óptico. Esse ruído aumenta a intensidade detectada e implica em uma análise de dados errada. Ele depende da fonte de luz ambiente, como lâmpadas e o próprio sol, e fica mais evidente quando a sua intensidade é semelhante ou maior que a do sinal detectado; no caso da medida da fluorescência de folhas com a fibra encostada na amostra, a iluminação por lâmpadas fluorescentes não inclui ruídos significativos aos dados, porém a luz solar pode ser detectada. Esse ruído pode ser minimizado se a leitura da fluorescência for realizada em um ambiente escuro.

Na Figura 4.2 mostramos um gráfico típico de fluorescência da folha quando excitada com $532 \mathrm{~nm}$; o destaque do gráfico revela o ruído óptico como uma linha de base no espectro. Essa linha de base implica erros nos cálculos matemáticos aplicados ao espectro, e por isso deve ser subtraída do gráfico. Na nossa análise, a linha de base foi determinada pelo menor valor das flutuações do sensor na região espectral entre 300 e $500 \mathrm{~nm}$, antes dos sinais de reflexão e fluorescência. Como pode ser visto no gráfico da Figura 4.2, a linha de base é, pelo menos, 500 vezes menor que o pico de emissão da fluorescência; isso revela que a subtração da linha de base era recomendada. 


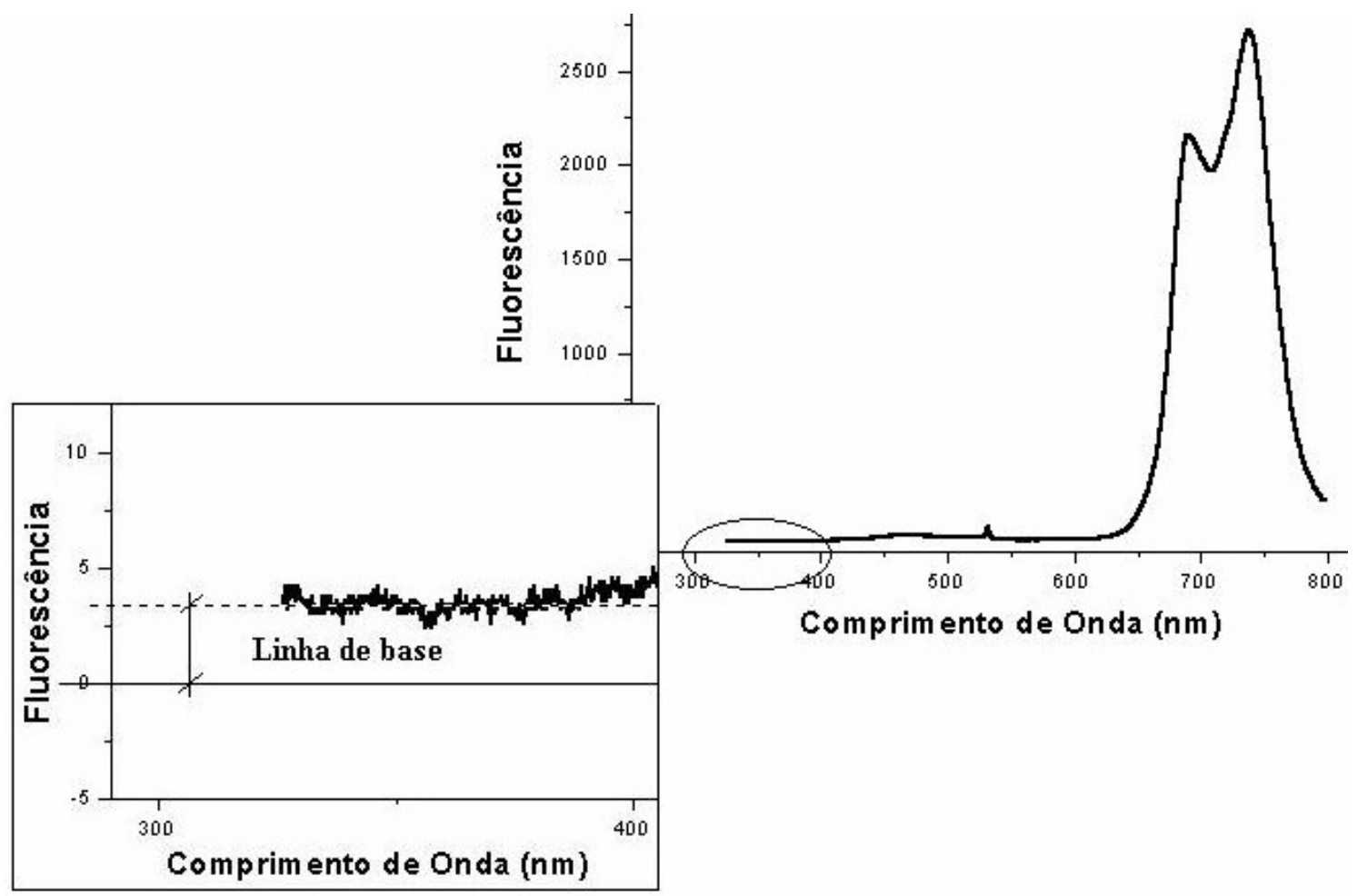

Figura 4.2 - Exemplo do ruído existente na medida da fluorescência de uma folha cítrica devido às flutuações na detecção do sensor do espectrômetro. No espectro coletado, esse ruído é representado por uma linha de base.

\subsubsection{Razões da fluorescência}

Com base na revisão da literatura científica (capítulo 2), duas figuras de mérito (FM) foram propostas para analisar os espectros detectados. São elas:

$$
F M_{1}=\frac{\int_{680}^{712} I(\lambda) d \lambda}{\int_{712}^{750} I(\lambda) d \lambda}
$$


Em geral as FM acima relacionam integrais das regiões espectrais e $I(\lambda)$ representa a intensidade da fluorescência detectada pelo espectrômetro. Como os dados do espectrômetro são valores discretos de intensidade, a integral de uma região é transformada no somatório das intensidades naquela mesma região e cada FM passa a relacionar áreas do espectro. Duas regiões espectrais são exploradas: o sinal detectado entre $680 \mathrm{~nm}$ e $800 \mathrm{~nm}$ se refere à intensidade total da fluorescência emitida pela clorofila e informa sobre a concentração da clorofila na folha ou sobre a eficiência quântica dos seus fotossistemas $(17,42)$. Essa região ainda é dividida em duas, onde ocorrem picos de emissão da fluorescência; o primeiro pico está entre $680 \mathrm{~nm}$ e $712 \mathrm{~nm}$ e o segundo pico está entre $712 \mathrm{~nm}$ e $750 \mathrm{~nm}$. A outra região espectral está entre $546 \mathrm{~nm}$ e $620 \mathrm{~nm}$ (amarelo-laranja). Essa região informa indiretamente sobre os efeitos de algum estresse na amostra, pois a sua emissão não está relacionada diretamente à clorofila, mas sim a outros mecanismos de defesa utilizados pelos vegetais para combater os estresses (17). Como pode ser observado, $\mathrm{FM}_{1}$ relaciona as regiões dos picos individuais da fluorescência emitida pela clorofila e $\mathrm{FM}_{2}$ relaciona a emissão total da clorofila com a emissão na região do amarelo-laranja.

\subsubsection{Resultados e discussões}

Os resultados destes experimentos foram publicados no jornal científico Laser Physics em 2006 (50) e são apresentados nos gráficos da Figura 4.3. Essa figura mostra gráficos da distribuição dos valores de $\mathrm{FM}_{1}$ e $\mathrm{FM}_{2}$, tomando ambos como coordenadas cartesianas. A Figura 4.3a relaciona as FM das amostras sadias e contaminadas com cancro cítrico; já a Figura 4.3b relaciona as FM das amostras contaminadas com cancro cítrico e CVC.

Vale a pena comentar ao leitor que as definições de $\mathrm{FM}_{1}$ e $\mathrm{FM}_{2}$ estão diferentes entre a tese e a referência (50), apesar de ambos exporem o mesmo conteúdo de dados e explorarem as mesmas regiões espectrais.

Na Figura 4.3a, o gráfico mostra que os valores de $\mathrm{FM}_{1}$ das amostras sadias não são maiores que 1, enquanto que o valores das amostras com cancro cítrico estão distribuídos entre 0.5 e 2.5. Este resultado prova que para as amostras sadias a intensidade emitida na região do $690 \mathrm{~nm}$ é sempre menor ou igual à emitida na região do $740 \mathrm{~nm}$, diferente das amostras contaminadas com cancro, onde há tanto casos onde a fluorescência na região do $690 \mathrm{~nm}$ é 
maior que na região do $740 \mathrm{~nm}$ quanto o inverso; esse resultado pode revelar um desbalanceamento dos sistemas fotossintéticos causados pelo cancro cítrico (50).
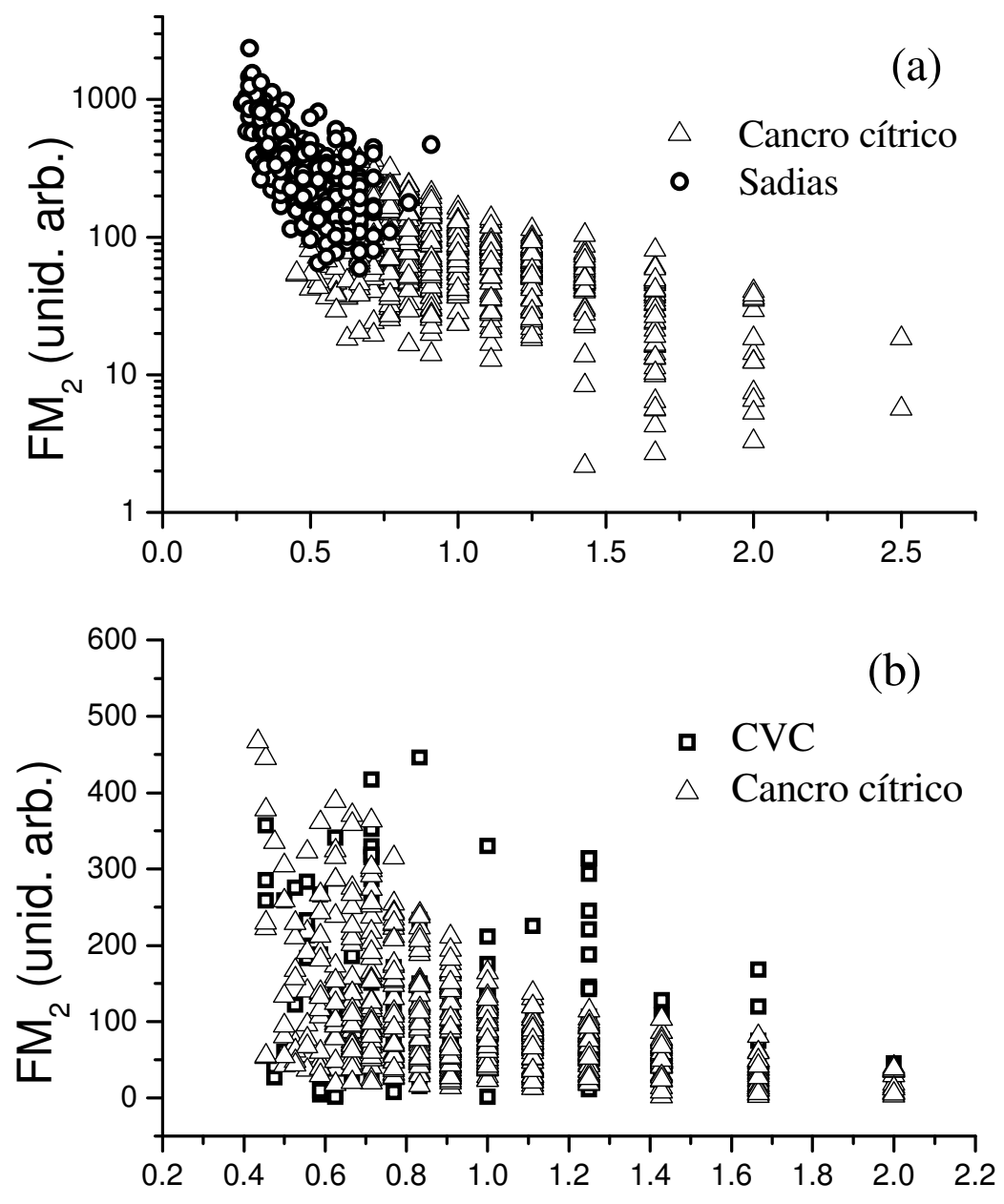

$\mathrm{FM}_{1}$ (unid. arb.)

Figura 4.3 - Distribuição dos valores de $\mathrm{FM}_{2}$ em função dos valores de $\mathrm{FM}_{1}$. Na figura (a) há a comparação entre as amostras sadias e as contaminadas com cancro cítrico; já na figura (b) o gráfico compara as amostras contaminadas por cancro cítrico com as contaminadas com CVC.

Os valores de $\mathrm{FM}_{2}$ revelam que eventualmente a emissão na região do amarelo-laranja é pelo menos 10 vezes menor que a emissão total da clorofila tanto nas sadias como nas infectadas. Porém também revela que a relação entre as regiões é no máximo de 400 vezes para as amostras infectadas e entre 40 e 2500 vezes para as amostras sadias. A limitação dos valores de $\mathrm{FM}_{2}$ para as amostras infectadas pode estar associada a um aumento da fluorescência na 
região amarelo-laranja ou um decréscimo da emissão geral da clorofila induzida pela degradação das suas moléculas.

A Figura $4.3 b$ faz relação similar à Figura 4.3a, porém relaciona as amostras infectadas por cancro cítrico com as amostras infectadas por CVC. Neste caso, os dois grupos de amostras apresentam valores tanto de $\mathrm{FM}_{1}$ quanto de $\mathrm{FM}_{2}$ com uma alta intersecção de intervalos. Certamente isto ocorre devido às semelhanças da manifestação das duas doenças sobre as amostras; uma hipótese possível é que ambas as doenças apresentem perdas semelhantes da concentração das clorofilas, o que implica emissão similar pelas amostras infectadas. Para confirmar essa hipótese serão necessários novos estudos e experimentos.

Nossos resultados nos permitem concluir que a LIF permite discriminar as folhas infectadas com cancro cítrico das folhas sadias. Contudo há uma grande dispersão nos dados obtidos para as amostras sadias. Esta dispersão pode ser devido a dois fatores distintos. O primeiro é o tempo de destacamento da folha e seu transporte até o laboratório, o qual precisava ser investigado. O segundo são as condições ambientais das plantas, pois há estudos na literatura onde foram observados estresse devido à temperatura com consequiência direta sobre os processos de fotossíntese e conseqüentemente sobre a característica da fluorescência emitida pelas folhas $(17,34)$. Da mesma forma o meio-ambiente também pode induzir estresse nas plantas por déficit de minerais e/ou água no solo (17).

\subsubsection{Influência do tempo de destacamento sobre a emissão da fluorescência pelas folhas}

Para investigar a influência do tempo de destacamento sobre o perfil espectral da emissão das amostras realizamos um experimento onde a fluorescência de folhas de plantas cítricas sadias foi medida em função do tempo no qual foram destacadas da planta de origem. Neste experimento quarenta folhas de uma planta sadia foram escolhidas como amostras e transportadas ao laboratório do IFSC para acompanhamento da fluorescência. As amostras foram coletadas na cidade de São Carlos e o tempo de transporte não excedeu 10 minutos. Três espectros foram medidos de cada uma das plantas e a partir de todos os 120 espectros foi calculado o espectro médio e o seu desvio padrão em cada hora. A medição da fluorescência foi realizada imediatamente ao chegar ao laboratório e durante as 12 horas seguintes, com 
leitura a cada hora. Esses resultados foram publicados no jornal internacional Precision Agriculture em 2009 (47).

Para análise, $\mathrm{FM}_{1}$ e $\mathrm{FM}_{2}$ foram estudadas a partir do espectro médio, calculando-as conforme a descrição neste texto. A Figura 4.4 mostra os resultados obtidos através do valor de $\mathrm{FM}_{1}$ (Figura 4.4a) e $\mathrm{FM}_{2}$ (Figura 4.4b) em função do tempo de destacamento das folhas. Cada ponto do gráfico é uma média sobre todas as amostras e a barra representa o desvio padrão da média.

$\mathrm{O}$ parâmetro $\mathrm{FM}_{1}$ apresenta uma variação temporal pequena e bem comportada, partindo de 0.5 e diminuindo seu valor original em cerca de $10 \%$ nas primeiras 4 horas; em seguida seu valor estabiliza. De forma diferente deste, $\mathrm{FM}_{2}$ parte do valor 50 e cresce quase linearmente nas 9 horas seguintes, atingindo o valor 400 (8x maior que o inicial); em seguida $\mathrm{FM}_{2}$ passa a diminuir.
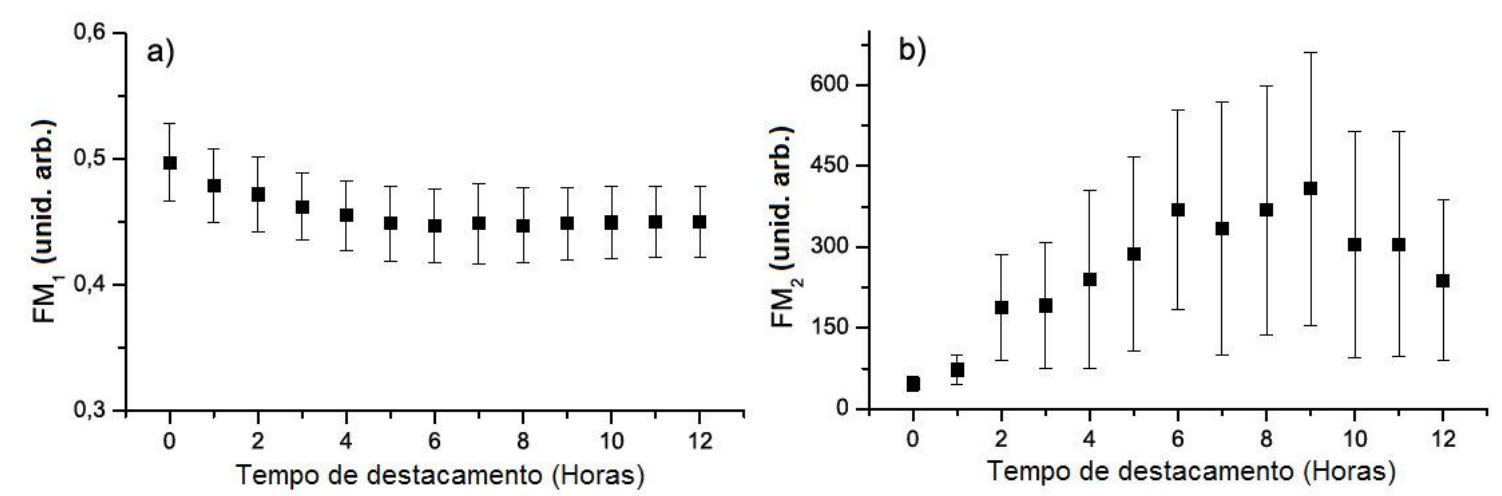

Figura 4.4 - Distribuição dos valores das figuras de mérito em função do tempo de destacamento das folhas. Na figura (a) há os valores de $\mathrm{FM}_{1}$ enquanto a figura (b) apresenta os valores de $\mathrm{FM}_{2}$.

Os dados revelam que $\mathrm{FM}_{2}$ varia quase uma ordem de magnitude em algumas horas. Além disso, os dados de $\mathrm{FM}_{2}$ apresentam uma dispersão larga, principalmente a partir de duas horas de destacamento da planta. Diante desta alta variância, optamos por observar os valores do numerador e do denominador de $\mathrm{FM}_{2}$. Isso nos revelou que em 12 horas o numerador de $\mathrm{FM}_{2}$ (somatório das intensidades entre 680 e $800 \mathrm{~nm}$ ) decresceu por um fator menor que 2, enquanto que o denominador (somatório das intensidades entre 547 e $620 \mathrm{~nm}$ ) decresceu por um fator de 10 e ainda apresentou um largo desvio padrão. De fato, o denominador de $\mathrm{FM}_{2}$ tem maior influência no comportamento deste resultado.

As variações apresentadas pelas FM estão relacionadas com os efeitos bioquímicos causados pelo destacamento das amostras das suas respectivas plantas originais, pois há processos que implicam tais mudanças nas folhas. É bem conhecido da literatura que os efeitos 
causados nas folhas pelo destacamento da planta dependem da espécie da planta. Porém, em geral há decréscimo do conteúdo da clorofila, do ácido ribonucléico (RNA), de proteínas, açúcares e de água. Além disso, há um desbalanceamento de íons na estrutura da folha. Todos esses fatores causam ineficiência nas atividades dos fotossistemas, o que leva à ineficiência da fotossíntese (42).

Fica claro que esse padrão revela o próprio processo de senescência da folha acelerado pelo seu destacamento da planta e pelo seu armazenamento em um recipiente escuro. A aceleração do processo de senescência da folha causado pelo destacamento da planta e armazenamento no escuro é quase imediata, como foi observado por Wardley e colaboradores em 1984 (69). Um efeito também esperado seria a degradação do número de cloroplastos por célula de uma planta, mas este efeito não ocorre no início do processo de senescência. De fato, os constituintes dos cloroplastos, citoplasmas e conteúdos das organelas são degradados durante os primeiros estágios da senescência, mas é apenas durante a evolução do processo que a taxa de cloroplastos por planta decresce (69). Todos esses efeitos são quase imediatos, embora os efeitos visuais só sejam percebidos horas depois.

\subsection{ESPECTROSCOPIA A FIBRA NO CAMPO}

\subsubsection{Nova metodologia}

Ficou claro que tanto o tempo de destacamento quanto os fatores ambientais podem influenciar a LIF. Assim para evitar tais influências alteramos nossa metodologia. A primeira alteração consiste em realizar a LIF diretamente no campo, reduzindo assim ao máximo o efeito de transporte das amostras. A segunda alteração na metodologia foi selecionar folhas sadias de doenças das mesmas plantas onde as folhas com sintomas das doenças foram coletadas. Essas folhas sadias foram utilizadas como referência das condições do clima e do ambiente sobre as plantas, este procedimento já tinha sido utilizado por M. Zhang e colaboradores em 2002 (70).

A última mudança foi tomar a planta, e não mais a folha, como entidade do diagnóstico do cancro cítrico. Diagnosticar as plantas infectadas, e não mais as folhas infectadas, im- 
plicam uma variância menor nos dados, pois o estado biológico da planta (doença) se estende a outras folhas da planta. Dessa forma, analisar o comportamento espectral de um conjunto de folhas se apresentava como uma alternativa mais interessante que analisar o comportamento de uma única folha. Esta decisão aumentou o número de folhas coletadas por planta (15 folhas) porém reduziu o número de espectros capturados por folha (1 único espectro). De cada planta analisada foram coletadas dez folhas apresentando sintomas visuais da doença e cinco folhas sadias. Como o comportamento dos espectros das amostras sadias era semelhante, foi realizada a média sobre os espectros de fluorescência das folhas sadias e a partir desse espectro médio as FM das sadias eram calculadas. De forma diferente, a partir dos espectros das dez folhas com sintomas foram calculadas dez valores de cada uma das FM, uma para cada folha, pois as variâncias dos dados poderiam ser relevantes para auxiliar as conclusões finais. Então, cada planta fornecia um conjunto de dados onde cada FM possuía dez valores de amostras com sintomas e um valor de amostra sadia.

Uma característica importante do espectrômetro portátil era a possibilidade de armazenar espectros resultantes da média de várias leituras. Com isso, passamos a medir apenas um único espectro por folha, sendo esse a média de 150 leituras da fluorescência emitida. A medida só era realizada 30 segundos depois da excitação, quando o sinal já se encontrava em estado permanente. Essa precaução minimiza a contribuição do "Efeito Kautsky" sobre a medida, onde a fluorescência sofre um transiente causado pelas moléculas reguladoras da entrada de luz na folha (17). Dessa forma o tempo total gasto em uma medida não ultrapassava 60 segundos.

Nestes experimentos foram analisadas um total de 224 plantas cítricas, compondo um conjunto de dados de 2240 espectros de amostras com sintomas visuais e 1120 espectros de amostras sadias. As variedades estudadas foram: Limão Cravo, Limão Galego, Limão Tahiti, Laranja Pêra, Laranja Valência e Tangerina Ponkan. As doenças estudadas foram: cancro cítrico (108 plantas), CVC (27 plantas), Verrugose (63 plantas), e o Greening (26 plantas) (24). Depois da medida da fluorescência, as amostras foram novamente transportadas em caixas de isopor aos laboratórios especializados no diagnóstico de doenças cítricas. O diagnóstico do laboratório foi utilizado mais uma vez como padrão-ouro para a análise do nosso método. 


\subsubsection{Análise dos espectros}

O pré-processamento dos espectros continuou neste novo procedimento. Depois da sua aplicação nos espectros com e sem sintomas as FM foram calculadas. Porém neste estágio, quatro novos parâmetros de análise foram incluídos, totalizando seis e não mais dois parâmetros. Duas novas figuras de mérito foram adicionadas, além da razão RF/FRF e de um índice da autocorrelação do espectro. Depois de todos os cálculos houve a normalização dos parâmetros com sintomas pelos parâmetros das sadias.

\subsubsection{Outras razões da fluorescência}

As novas figuras de mérito incluídas na análise estão definidas abaixo. Semelhante às primeiras $\mathrm{FM}, \mathrm{FM}_{3}$ e $\mathrm{FM}_{4}$ relacionam o somatório das intensidades em regiões espectrais bem definidas. Nestas equações a intensidade detectada pelo espectrômetro continua representada por $\mathrm{I}(\lambda)$.

$$
F M_{3}=\frac{\int_{680}^{800} I(\lambda) d \lambda}{\int_{520}^{540} I(\lambda) d \lambda}
$$

Uma nova região espectral está sendo explorada além das que foram definidas na secção 4.1.2. O sinal detectado entre $520 \mathrm{~nm}$ e $540 \mathrm{~nm}$ informa sobre a intensidade do LASER refletida pela superfície da amostra e capturada pela fibra de coleta. Dessa forma, definimos $\mathrm{FM}_{3}$ como a relação entre a emissão total da clorofila e a reflexão do LASER e FM 4 como a relação entre a emissão no amarelo-laranja e a reflexão do LASER pela amostra. Além dessas 
FM descritas, optamos por analisar a razão RF/FRF. Conforme mostra a equação 4.5, essa razão relaciona a intensidade dos picos da fluorescência emitida pela clorofila em $690 \mathrm{~nm}$ e em $740 \mathrm{~nm}(46)$.

$$
R F / F R F=\frac{I(690 \mathrm{~nm})}{I(740 \mathrm{~nm})}
$$

Essa razão é bem referenciada e aceita pela comunidade científica e se assemelha com $\mathrm{FM}_{1}$. De fato, RF/FRF e $\mathrm{FM}_{1}$ possuem o mesmo significado, mas RF/FRF relaciona os picos monocromáticos da emissão e $\mathrm{FM}_{1}$ relaciona as bandas espectrais onde os picos de emissão ocorrem. A justificativa para $\mathrm{FM}_{1}$ é que a literatura reporta que as condições ambientais podem deslocar os picos de emissão da clorofila em alguns nanômetros (17). Para que nossa análise não sofresse influência significativa devido ao deslocamento dos picos de emissão, optamos por analisar, também, as bandas espectrais onde os picos ocorrem.

\subsubsection{Autocorrelação do espectro da fluorescência}

Uma forma de avaliar a relação linear entre duas funções matemáticas ou dois sinais distintos é a autocorrelação. Estatisticamente, essa ferramenta informa a respeito da influência do valor $\mathrm{F}\left(\mathrm{p}_{0}\right)$ de uma função $\mathrm{F}(\mathrm{p})$ no ponto $\mathrm{p}_{0}$ sobre os valores da mesma função nos pontos vizinhos. Nosso interesse se dirige para a aplicação da autocorrelação sobre os espectros da fluorescência, pois ela enfatiza as variações espectrais, revelando mudanças no espectro que não foram percebidas através das razões. Existem várias definições e interpretações da autocorrelação na física, matemática e estatística, por isso nossa autocorrelação foi escolhida se baseando no fato que o espectro da fluorescência não é periódico e tem valores discretos e não-nulos distribuídos em um intervalo espectral finito. Dessa forma, a autocorrelação $C\left(\lambda_{0}\right)$ foi definida abaixo:

$$
C\left(\lambda_{0}\right)=\sum_{\lambda=540}^{800} I(\lambda) I\left(\lambda-\lambda_{0}\right)
$$


$\mathrm{Na}$ equação 4.6, $I(\lambda)$ é a intensidade de fluorescência emitida da varredura do somatório e $I\left(\lambda-\lambda_{0}\right)$ é a intensidade de fluorescência emitida deslocada $\lambda_{0}$ comprimentos de onda no espectro. Para limitar o cálculo à área espectral definida (540 nm a $800 \mathrm{~nm})$, as intensidades de fluorescência fora do intervalo foram substituídas por zero. Uma vez que o préprocessamento do espectro força valores positivos e não-nulos dentro do intervalo determinado, os resultados mostraram que a informação da autocorrelação poderia ser obtida e comparada entre espectros diferentes calculando um único valor da autocorrelação, e não mais todos os valores. Decidimos estudar apenas $C\left(\lambda_{0}=0\right)$ por ser o maior dos valores possíveis da autocorrelação; esperávamos, dessa forma, que a diferença entre os valores $C(0)$ de dois espectros diferentes fosse máxima.

\subsubsection{Parâmetros normalizados}

O último processamento aplicado foi a normalização dos parâmetros das amostras sintomáticas pelos das amostras sadias. Como descrevemos antes, buscamos tomar as amostras sadias como referência das condições ambientais da fazenda. A equação 4.7 demonstra o cálculo para obter $\mathrm{FM}_{1 \mathrm{n}}$.

$$
F M_{1 n}=\frac{F M_{1}(\text { sintomáticos })}{F M_{1}(\text { sadias })}
$$

$\mathrm{O}$ índice $\mathrm{n}$ indica o parâmetro normalizado. Esse mesmo procedimento foi aplicado a cada um dos parâmetros propostos. Vale lembrar que o denominador da equação 4.7 é um simples valor, pois é calculado a partir de um espectro médio, porém há 10 valores de $\mathrm{FM}_{1}$ por planta, o que implica média e desvio padrão no valor de $\mathrm{FM}_{1 \mathrm{n}}$. 


\subsubsection{Resultados e discussões}

Os resultados da LIF aplicada no campo são apresentados no apêndice A através de uma tabela contendo a variedade da planta, a doença diagnosticada por inspeção visual, seus parâmetros normalizados e os resultados do padrão-ouro para diagnóstico do cancro. Vale destacar que o diagnóstico da doença através dos sintomas visuais (na tabela do apêndice A “Classificação do pragueiro") foi realizado pelo pesquisador do FUNDECIRUS José Belasque Júnior, com a intenção de obter uma alta taxa de acerto na escolha das amostras estudadas. Desta tabela construímos a tabela resumida 4.1. Ela apresenta o valor médio (m) e o desvio padrão (dp) de cada parâmetro normalizado, para cada uma das doenças estudadas.

Tabela 4.1 - Valor médio (m), desvio padrão (dp) e número de amostras (n) de todos os parâmetros normalizados $\left(\mathrm{FM}_{1 \mathrm{n}}, \mathrm{FM}_{2 \mathrm{n}}, \mathrm{FM}_{3 \mathrm{n}}, \mathrm{FM}_{4 \mathrm{n}}, \mathrm{C}(0)_{\mathrm{n}} \mathrm{e} \mathrm{RF} / \mathrm{FRF}_{\mathrm{n}}\right)$ para cada uma das doenças: cancro cítrico, verrugose, greening e clorose variegada dos cítricos (CVC).

\begin{tabular}{ccccccccccccc}
\hline \multirow{2}{*}{ Parâmetroo } & \multicolumn{3}{c}{ Cancro cítrico } & \multicolumn{3}{c}{ Verrugose } & \multicolumn{3}{c}{ Greening } & \multicolumn{3}{c}{ CVC } \\
\cline { 2 - 13 } & $\mathbf{m}$ & $\mathbf{d p}$ & $\mathbf{n}$ & $\mathbf{m}$ & $\mathbf{d p}$ & $\mathbf{N}$ & $\mathbf{m}$ & $\mathbf{d p}$ & $\mathbf{n}$ & $\mathbf{m}$ & $\mathbf{d p}$ & $\mathbf{n}$ \\
\hline $\mathrm{FM}_{1 \mathrm{n}}$ & 1.5 & 0.2 & 108 & 1.1 & 0.2 & 63 & 1.6 & 0.2 & 26 & 2.0 & 0.3 & 27 \\
\hline $\mathrm{FM}_{2 \mathrm{n}}$ & 50.9 & 122.8 & 101 & 51.6 & 150 & 61 & 43.4 & 103.8 & 26 & 20.4 & 32.6 & 27 \\
\hline $\mathrm{FM}_{3 \mathrm{n}}$ & 0.9 & 0.3 & 105 & 1.0 & 0.4 & 63 & 0.9 & 0.8 & 26 & 0.8 & 0.5 & 27 \\
\hline $\mathrm{FM}_{4 \mathrm{n}}$ & 20.8 & 66.1 & 92 & 11.0 & 29.7 & 60 & 6.2 & 5.9 & 26 & 7.0 & 6.4 & 27 \\
\hline $\mathrm{C}(0)_{\mathrm{n}}$ & 1.0 & 1.5 & 104 & 1.6 & 3.8 & 63 & 1.9 & 4.7 & 26 & 0.6 & 0.6 & 27 \\
\hline $\mathrm{RF} / \mathrm{FRF}_{\mathrm{n}}$ & 2.0 & 0.5 & 108 & 1.3 & 0.4 & 63 & 2.1 & 0.5 & 26 & 3.0 & 0.65 & 27 \\
\hline
\end{tabular}

A tabela 4.1 ainda informa o número de amostras (n) utilizadas no cálculo de cada um dos parâmetros analisados; para o cancro cítrico e a verrugose esse número de amostras é diferente entre os parâmetros. Isso ocorre porque alguns cálculos computacionais resultaram "infinito" devido à divisão por zero ou por calcular um número além do intervalo definido pelo seu formato computacional. Esses valores foram excluídos da análise dos dados.

Para todas as doenças o parâmetro que apresentou a menor dispersão dos dados foi $\mathrm{FM}_{1 \mathrm{n}}$ por apresentar os menores valores, absolutos e percentuais, de desvio padrão. Comparativamente, menores variâncias também foram observadas para $\mathrm{FM}_{3 n}, \mathrm{C}(0)_{\mathrm{n}}$ e $\mathrm{RF} / \mathrm{FRF}$. De posse desses dados, as figuras de mérito $\mathrm{FM}_{2 \mathrm{n}}$ e $\mathrm{FM}_{4 \mathrm{n}}$ foram excluídas da análise e apenas os outros quatro parâmetros foram utilizados para efetuar o diagnóstico do cancro cítrico. Cinco critérios de discriminação do cancro foram definidos, os quais estão definidos abaixo: 
(i). Critério $1(\mathrm{C} 1)$ - Amostra positiva para $\mathrm{FM}_{1 \mathrm{n}} \geq 1.25$ e negativa para $\mathrm{FM}_{1 \mathrm{n}}<1.25$;

(ii). Critério $2(\mathrm{C} 2)$ - Amostra positiva para $\mathrm{FM}_{1 \mathrm{n}} \geq 1.43$ e negativa para $\mathrm{FM}_{1 \mathrm{n}}<1.1$. Quando $1.1 \leq \mathrm{FM}_{1 \mathrm{n}}<1.43$, amostra positiva para $\mathrm{FM}_{3 \mathrm{n}} \leq 1.0$ e negativa para $\mathrm{FM}_{3 \mathrm{n}}>$ 1.0

(iii). Critério $3(\mathrm{C} 3)$ - Amostra positiva para $\mathrm{FM}_{1 \mathrm{n}} \geq 1.43$ e negativa para $\mathrm{FM}_{1 \mathrm{n}}<1.1$. Quando $1.1 \leq \mathrm{FM}_{1 \mathrm{n}}<1.43$, amostra positiva para $\mathrm{C}(0)_{\mathrm{n}} \leq 1.0$ e negativa para $\mathrm{C}(0)_{\mathrm{n}}>$ 1.0 ;

(iv). Critério $4(\mathrm{C} 4)$ - Amostra positiva para $\mathrm{FM}_{1 \mathrm{n}} \geq 1.43$ e negativa para $\mathrm{FM}_{1 \mathrm{n}}<1.1$. Quando $1.1 \leq \mathrm{FM}_{1 \mathrm{n}}<1.43$, amostra positiva para $\mathrm{RF} / \mathrm{FRF}_{\mathrm{n}} \geq 1.35$ e negativa para $\mathrm{RF} / \mathrm{FRF}_{\mathrm{n}}<1.35$.

(v). Critério 5 (C5) - Amostra positiva para $1.25 \leq \mathrm{FM}_{1 \mathrm{n}}<1.82$ e negativa para $\mathrm{FM}_{1 \mathrm{n}}<$ 1.11 ou $\mathrm{FM}_{1 \mathrm{n}} \geq 1.82$. Quando $1.1 \leq \mathrm{FM}_{1 \mathrm{n}}<1.25$, amostra negativa para $\mathrm{FM}_{3 \mathrm{n}} \geq 1.2 \mathrm{e}$ positiva para $\mathrm{FM}_{3 \mathrm{n}} \leq 0.9$. Quando $0.9<\mathrm{FM}_{3 \mathrm{n}}<1.2$, amostra positiva para $\mathrm{RF} / \mathrm{FRF}_{\mathrm{n}}>$ 1.35 e negativa para $\mathrm{RF} / \mathrm{FRF}_{\mathrm{n}} \leq 1.35$.

Para uma melhor compreensão dos critérios de análise dos parâmetros, as Figuras 4.5, 4.6, 4.7, 4.8 e 4.9 apresentam fluxogramas organizacionais dos testes dos parâmetros C1, C2, C3, C4 e C5, respectivamente.

Antes da análise dos critérios um ponto importante deve ser explicado. É fato, que no dia-a-dia dos inspetores de campo do FUNDECITRUS, a primeira ferramenta aplicada no diagnóstico de doenças é a inspeção visual. A experiência prática dos inspetores de campo é determinante nesta questão, pois eles confirmam que os sintomas das doenças, apesar de semelhantes, não são idênticos, e que é possível distinguir o greening e a CVC do cancro cítrico apenas por seus sintomas visuais. Dificuldade maior há em distinguir a verrugose do cancro cítrico apenas pelos sintomas visuais. Sendo assim, esse hábito nos permite minimizar o grupo de amostras testadas buscando minimizar o número de falsos positivos e negativos.

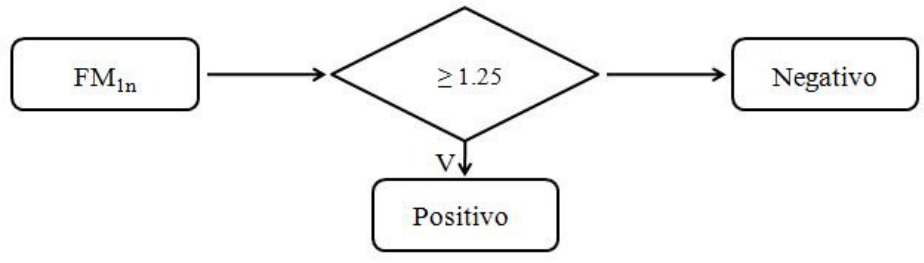

Figura 4.5 - Fluxograma organizacional do critério C1, que testa os valores de $\mathrm{FM}_{1 \mathrm{n}}$. 


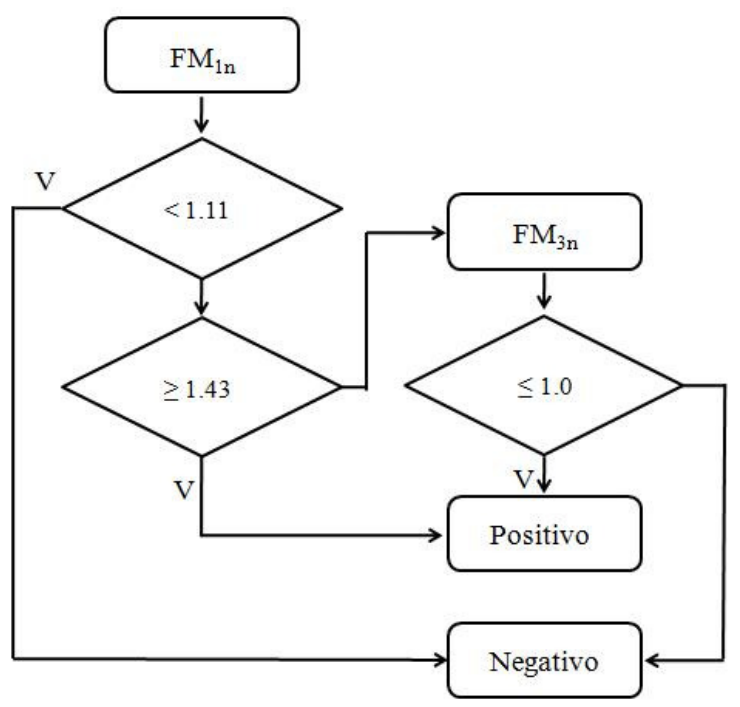

Figura 4.6 - Fluxograma organizacional do critério C2. Neste critério $\mathrm{FM}_{1 \mathrm{n}}$ e $\mathrm{FM}_{3 \mathrm{n}}$ são testados, porém a informação de $\mathrm{FM}_{1 \mathrm{n}}$ tem a preferência de determinar o diagnóstico.

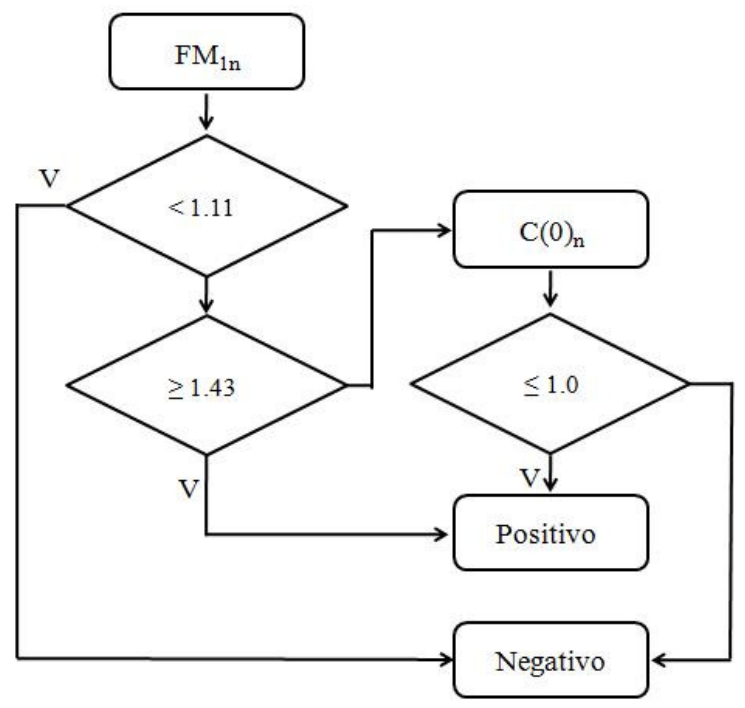

Figura 4.7 - Fluxograma organizacional do critério C3. Neste critério $\mathrm{FM}_{1 \mathrm{n}}$ e $\mathbf{C}(\mathbf{0})_{\mathrm{n}}$ são testados, porém aqui também a informação de $\mathrm{FM}_{1 \mathrm{n}}$ tem a preferência para diagnóstico do cancro cítrico. 


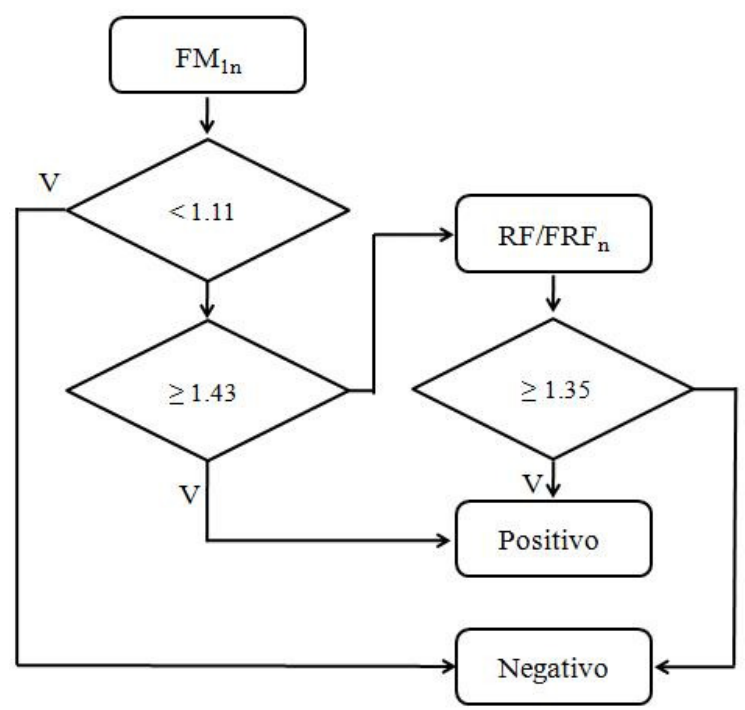

Figura 4.8 - Fluxograma organizacional do critério $C 4$. Neste critério $F M_{1 \mathrm{n}}$ e $R F / F R F_{n}$ são testados, porém, novamente, a informação de $\mathrm{FM}_{1 \mathrm{n}}$ tem a preferência para diagnóstico do cancro cítrico.

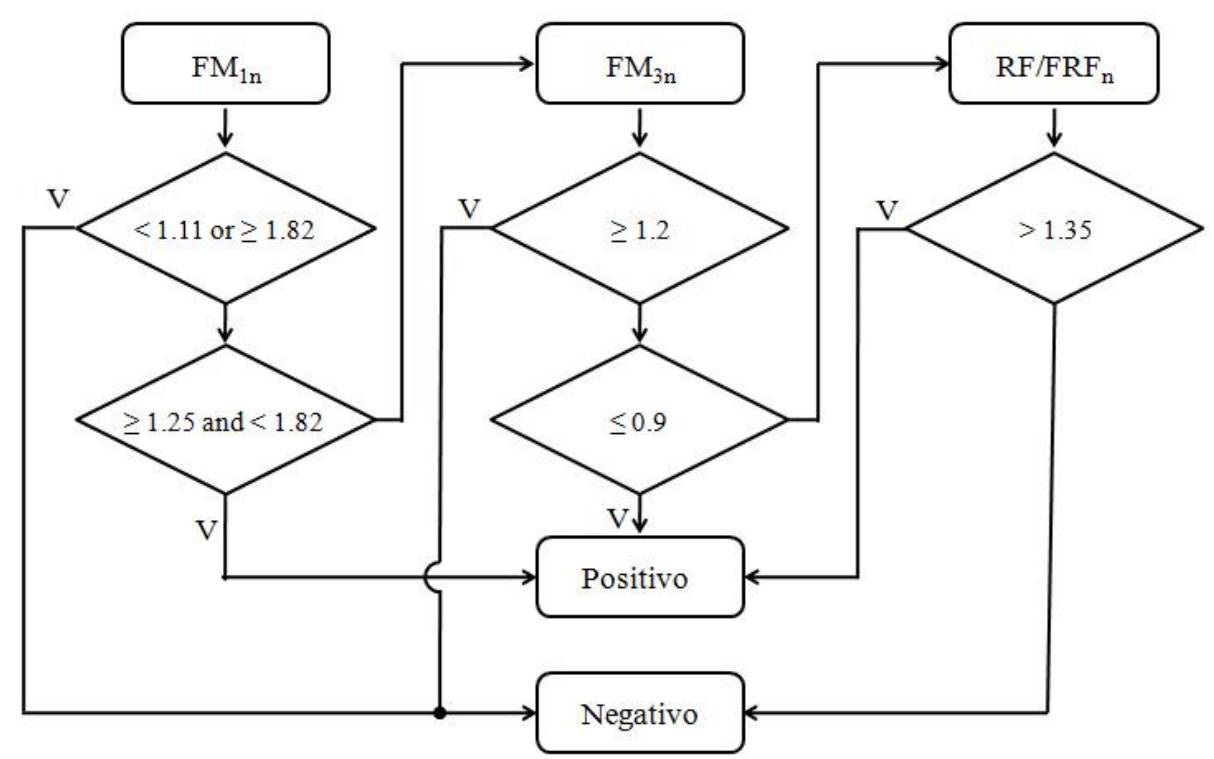

Figura 4.9 - Fluxograma organizacional do critério C5. Este critério testa os valores de $\mathrm{FM}_{1 \mathrm{n}}, \mathrm{FM}_{3 \mathrm{n}}$ e $\mathrm{RF}_{\text {FRF }}$. Este critério apresenta uma hierarquia de testes, $\mathrm{FM}_{1 \mathrm{n}}$ são testados primeiro, seguido por $\mathrm{FM}_{3 \mathrm{n}}$ e por último $R F / F_{R F}$.

Por isso, limitamos o conjunto de dados dos critérios C1, C2, C3 e C4 às amostras contaminadas com cancro e verrugose apenas. Já C5 foi aplicado sobre os dados do cancro cítrico, verrugose e CVC, pois também desejávamos avaliar os dados do CVC. Os dados do greening não fizeram parte da análise dos critérios, pois seus sintomas visuais são tão distintos das demais doenças que, como mencionado antes, apenas a inspeção visual é suficiente para realizar a discriminação. O resultado dos critérios de detecção foi comparado com o diagnós- 
tico do padrão-ouro fornecido pelos laboratórios credenciados. A partir desses dados foram montados testes de classificação binária (testes de diagnóstico) entre cada um dos critérios e o padrão-ouro. O resultado final dos testes de diagnóstico é o número de verdadeiros positivos (VP), verdadeiros negativos (VN), falsos positivos (FP) e falsos negativos (FN) de cada critério. A partir desses valores foram calculados os parâmetros estatísticos sensibilidade (S), especificidade (E), valor preditivo positivo (VPP), valor preditivo negativo (VPN), precisão (P), acurácia (A), razão de verossimilhança positiva (RVP) e razão de verossimilhança negativa (RVN), os quais estão definidos abaixo:

$$
\begin{aligned}
& S=\frac{V P}{V P+F N} \\
& E=\frac{V N}{V N+F P} \\
& V P P=\frac{V P}{V P+F P} \\
& V P N=\frac{V N}{V N+F N} \\
& P=\frac{V P+F N}{V P+V N+F P+F N} \\
& A=\frac{V P+V N}{V P+V N+F P+F N} \\
& R V P=\frac{S}{1-E} \\
& R V N=\frac{1-S}{E}
\end{aligned}
$$

Tais resultados foram divididos em duas tabelas. A Tabela 4.2 apresenta VP, FP, FN e VN dos critérios de diagnose do cancro. Além desses, essa tabela fornece o número de plantas testadas $(\mathrm{N})$ e o percentual de acertos e erros dentro do conjunto. Como relatado antes, C5 possui o maior conjunto de amostras por envolver três tipos de doenças (198 plantas), enquanto os demais critérios testaram apenas dois tipos de doenças (no máximo 171 plantas). A Tabela 4.3 apresenta os resultados dos parâmetros estatísticos calculados a partir dos dados da Tabela 4.2. A partir das tabelas, pode-se destacar o melhor desempenho de C4 sobre os demais critérios que discriminam o cancro da verrugose apenas (C1, C2, C3 e C4). Tal critério apresenta o maior número percentual de acertos (82\%), o menor número de falsos positivos 
(24), que são responsáveis por cortar árvores que não estão contaminadas, e o menor número de falsos negativos (7), que são responsáveis por proliferar a doença; além disso, apresenta os maiores valores de especificidade (63\%), valores preditivos, acurácia e verossimilhanças. Mesmo assim, os resultados dos demais critérios estão próximos aos de $\mathrm{C} 4$, exceto a especificidade e a verossimilhança positiva, indicando que de uma forma geral, o desempenho dos critérios é semelhante.

Tabela 4.2 - Número de verdadeiros positivos (VP), verdadeiros negativos (VN), falsos positivos (FP) e falsos negativos (FN) de cada critério estudado para o diagnóstico do cancro cítrico. A tabela ainda fornece o número de amostras testadas por cada critério e o seu número de acertos e erros dentro do grupo.

\begin{tabular}{cccccccc}
\hline Critério & VP & FP & FN & VN & N & Acertos & Erros \\
\hline C1 & 101 & 28 & 8 & 34 & 171 & $79 \%$ & $21 \%$ \\
\hline C2 & 97 & 28 & 9 & 34 & 168 & $78 \%$ & $22 \%$ \\
\hline C3 & 96 & 30 & 6 & 35 & 167 & $78 \%$ & $22 \%$ \\
\hline C4 & 99 & 24 & 7 & 41 & 171 & $82 \%$ & $18 \%$ \\
\hline C5 & 92 & 30 & 12 & 64 & 198 & $79 \%$ & $21 \%$ \\
\hline
\end{tabular}

Tabela 4.3 - Parâmetros estatísticos calculados a partir dos dados da Tabela 4.2: sensibilidade (S), especificidade (E), valor preditivo positivo (VPP), valor preditivo negativo (VPN), precisão (P), acurácia (A), razão de verossimilhança positiva (RVP) e razão de verossimilhança negativa (RVN).

\begin{tabular}{ccccccccc}
\hline Critério & $\mathbf{S}$ & $\mathbf{E}$ & $\mathbf{V P P}$ & $\mathbf{V P N}$ & $\mathbf{P}$ & $\mathbf{A}$ & $\mathbf{R V P}$ & $\mathbf{R V N}$ \\
\hline C1 & 0,93 & 0,55 & 0,78 & 0,81 & 0,64 & 0,79 & 2,05 & 0,13 \\
\hline C2 & 0,92 & 0,55 & 0,78 & 0,79 & 0,63 & 0,78 & 2,03 & 0,15 \\
\hline C3 & 0,94 & 0,54 & 0,76 & 0,85 & 0,61 & 0,78 & 2,04 & 0,11 \\
\hline C4 & 0,93 & 0,63 & 0,80 & 0,85 & 0,62 & 0,82 & 2,53 & 0,10 \\
\hline C5 & 0,88 & 0,68 & 0,75 & 0,84 & 0,53 & 0,79 & 2,77 & 0,17 \\
\hline
\end{tabular}

O desempenho de C5 deve ser analisado a parte, devido ao seu grupo amostral ser diferente dos demais. Apesar da menor sensibilidade (88\%), este critério possui a maior especificidade de diagnóstico (68\%); já a acurácia (79\%) é semelhante às demais. Observando em termos gerais, C5 tem o mesmo desempenho que os outros critérios, pois seus índices percentuais de erros e acertos são semelhantes aos dos outros.

As mudanças adotadas nessa nova metodologia diminuíram significativamente a dispersão dos dados. Essa conclusão se dá, pois com os primeiros resultados da espectroscopia a fibra não era possível distinguir os tipos de doença devido à variância dos dados, nesta segunda metodologia as mesmas razões espectrais foram estudadas e possibilitaram o cancro cítrico se discriminado tanto da verrugose quanto da CVC. 
Os resultados também comprovaram que com a nova metodologia, o melhor resultado obtido apresenta uma sensibilidade de $93 \%$, uma especificidade de $63 \%$ e acurácia de $82 \%$; tais valores são considerados baixos para aprovar uma nova técnica de diagnóstico, que requer pelo menos 95\% de acurácia. Quando aplicadas sobre um grupo composto por cancro cítrico, verrugose e CVC o desempenho é inferior para sensibilidade e acurácia, provando que a metodologia deve ser melhorada.

$\mathrm{Na}$ tentativa de entender a razão de uma acurácia tão baixa, observamos os valores de $\mathrm{FM}_{1 \mathrm{n}}$ para cada uma das plantas que foram classificadas como falso positivo ou falso negativo. Nestas plantas, ou as folhas sintomáticas ou as sadias ou ambas induziam um grande desvio padrão nos valores de $\mathrm{FM}_{1 \mathrm{n}}$. Em geral este desvio percentual estava entre 25 a $35 \%$. As plantas, classificadas corretamente (verdadeiro positivo ou negativo), apresentavam desvios percentuais entre 5 e $15 \%$.

Com certeza este alto desvio percentual está prejudicando a acurácia da técnica; acreditamos que sua origem advém da escolha da região onde a espectroscopia é realizada. Desde o início a fibra de coleta da fluorescência tem sido colocada entre a necrose e o tecido com aspecto visual sadio. Como a fibra tem uma área de coleta da ordem de $1 \mathrm{~mm}^{2}$, não fica claro que ela estivesse sendo sempre colocada no melhor lugar da folha. Mesmo nas folhas consideradas sadias em uma planta, não fica claro que o melhor local sempre foi escolhido; afinal temos evidências de pequenas alterações em uma mesma folha.

Dessa forma, para melhorar a acurácia há duas possibilidades: realizar mais médias tanto para as folhas sintomáticas quanto para as folhas sadias ou realizar espectroscopia das imagens da fluorescência. Aumentar o número de médias envolveria aumentar o número de folhas para, pelo menos, 40 folhas sintomáticas e/ou 20 folhas sadias. Aumentar em 4 vezes o número de amostras implica diminuir a variância em 2 vezes. Infelizmente nem sempre há esta quantidade de folhas sintomáticas em uma planta. Além disso, todo este procedimento levaria mais de uma hora para ser realizando, contrariando nosso objetivo inicial.

Fica claro que a segunda opção é a mais viável. A própria evolução dos sistemas direciona para análises através da espectroscopia das imagens da fluorescência. A espectroscopia por imagens possibilita a resolução espacial e espectral da fluorescência emitida, dessa forma mais de uma região da lesão pode ser estudada ao mesmo tempo. 


\section{ESPECTROSCOPIA DE IMAGENS DA FLUORESCÊNCIA}

Este capítulo será dedicado aos experimentos pilotos para diagnóstico do cancro cítrico utilizando a espectroscopia de imagens da fluorescência. Inicialmente serão apresentadas as imagens espectrais baseadas no sistema com o espectrógrafo (SIE), na seqüência os resultados baseados no sistema com uma roda de filtros (SIF) são apresentados.

\subsection{EXPERIMENTOS COM O SISTEMA COM O ESPECTRÓGRAFO}

Nesse estágio da pesquisa nós dispúnhamos de um novo instrumento, mas não conhecíamos o seu desempenho nos experimentos. Por isso, inicialmente optamos por observar as principais mudanças espectrais que poderiam ser detectadas pelas imagens antes de realizar as viagens para coletar um largo número de amostras, e a partir dessas mudanças determinamos novos parâmetros que pudessem ser utilizados para a discriminação eficaz das doenças. Por isso, apesar de toda informação obtida da espectroscopia a fibra, houveram mudanças na metodologia adotada para os experimentos com o SIE, na intenção de aproveitar a informação fornecida pelas imagens espectrais com a máxima eficiência.

\subsubsection{Metodologia na coleta das imagens}

Nesta etapa o grupo de espécies de plantas cítricas foi minimizado. Uma vez que as folhas eram coletadas de fazendas comerciais, as quais possuem um pequeno número de variedades, apenas as espécies Laranja pêra e Laranja valência foram estudadas. Apesar disso, as doenças estudadas foram o cancro cítrico, a verrugose, a CVC e o greening.

Outra mudança ocorreu no tempo total gasto para leitura de uma amostra, pois no SIE demorava cerca de 30 minutos contra 1 minuto gasto pelo espectrômetro. O tempo de exposição da CCD era um dos fatores que contribuía para os 30 minutos por amostra, pois a exposição da CCD deveria ser entre 20 e 40 segundos para que a imagem espectral apresentasse um 
contraste razoável e uma razão sinal-ruído satisfatória. O outro fator era o número de imagens capturadas para estudar toda a região de interesse em uma amostra, em geral o comprimento das amostras era entre 50 e $60 \mathrm{~mm}$ o que necessita a captura entre 50 e 60 imagens (fenda) por folha. Caso o campo de visão fosse ampliado pela objetiva com a intenção de minimizar o número de imagens capturadas havia diminuição da resolução espacial na imagem espectral.

Sendo assim, naquele momento ficou inviável realizar um experimento com um grande número de amostras. Uma possível solução seria a substituição da câmera por uma mais sensível, que necessitasse um menor tempo de integração para fornecer um contraste razoável. Enquanto nos experimentos da LIF foram testadas centenas de amostras; agora, apenas unidades de amostras foram experimentadas. Inicialmente esse número parece ser baixo, mas a quantidade de informação contida nas imagens espectrais é muito maior que a contida em um único espectro de fluorescência.

Neste experimento foram testadas 4 folhas infectadas por cancro cítrico, 4 com verrugose, 4 com CVC e 4 com greening. Além dessas, imagens de folhas sadias também foram feitas para normalizar os dados das sintomáticas. Uma vez que as amostras chegavam ao laboratório eram armazenadas em uma caixa de isopor com um recipiente de água para manutenção da temperatura e da umidade do ambiente. Antes de cada leitura a amostra era fixada sobre uma superfície de alumínio anodizado que servia como fundo da imagem. O passo do motor do scanner era selecionado conforme a escolha dos parâmetros $\Delta \mathrm{C}$ e $\Delta \mathrm{L}$ da imagem espectral. Em geral foi utilizado um campo de visão de $40 \mathrm{~mm}$ e uma largura de $1 \mathrm{~mm}$.

\subsubsection{Efeito da fonte de excitação}

Como já foi descrito no capitulo 3, o sistema foi construído para permitir duas excitações possíveis, azul em $470 \pm 10 \mathrm{~nm}$ e violeta em $405 \pm 15 \mathrm{~nm}$. Vale lembrar que o espectrômetro utilizava excitação em $532 \mathrm{~nm}$ (verde) enquanto que o SIE excita na região do violetaazul. Esses comprimentos de onda foram escolhidos devido às folhas absorverem mais radiação na região do violeta-azul que no verde (17). Para o espectrômetro, o LASER verde foi útil na compactação do sistema.

Assim, nosso primeiro teste do sistema foi realizar uma imagem de uma folha de laranjeira contaminada por CVC com os dois comprimentos de onda de excitação. Cada grupo 
de diodos proveu cerca de $25 \mathrm{~mW} / \mathrm{cm}^{2}$ sobre a amostra. A justificativa para testar uma amostra contaminada foi analisar a intensidade de emissão na região entre a necrose e a região sem sintomas. Por isso, uma região de interesse foi escolhida e a intensidade nessa região foi verificada. Para estas imagens, o tempo de exposição da CCD foi 20 segundos.

Os resultados são apresentados na Figura 5.1, que mostra uma imagem digital da amostra (Figura 5.1a), o detalhe da região de interesse (Figura 5.1b) e as imagens espectrais quando a excitação é por luz azul (Figuras 5.1c e 5.1d) ou por luz violeta (Figuras 5.1e e 5.1f). Dentre as imagens espectrais, as Figuras 5.1c e 5.1e são da emissão em 690 nm, enquanto as Figuras 5.1d e 5.1f são da emissão em 740 nm.
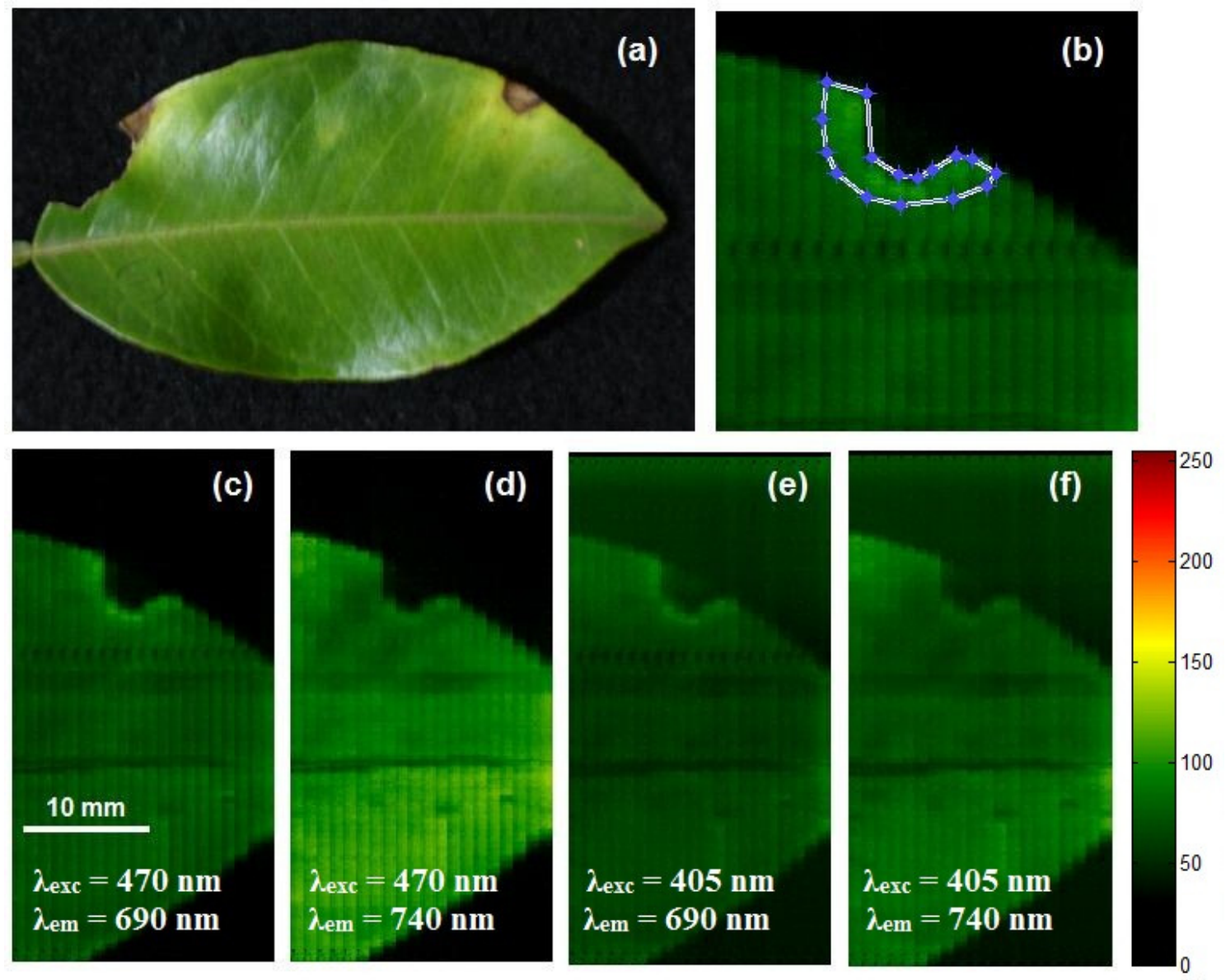

Figura 5.1 - Teste comparativo da intensidade de fluorescência detectada pelo SIE quando luz azul ou violeta é utilizada para excitação. (a) Imagem digital da amostra. (b) Região de interesse selecionada na imagem espectral; destaca-se que essa região se refere à parte amarelada da lesão. (c) Imagem espectral com excitação no azul e emissão em $690 \mathrm{~nm}$. (d) Imagem espectral com excitação no azul e emissão em 740 nm. (e) Imagem espectral com excitação no violeta e emissão em $690 \mathrm{~nm}$. (f) Imagem espectral com excitação no violeta e emissão em $740 \mathrm{~nm}$. Para formar as imagens o tempo de exposição foi 20 segundos e a intensidade de iluminação $25 \mathrm{~mW} / \mathrm{cm}^{2}$. 
Nessas imagens o padrão de falsas cores foi utilizado para aumentar o contraste nas imagens. Elas provam que na ROI a excitação por luz azul induz uma intensidade média da emissão maior que a excitação por luz violeta tanto na região com pico em $690 \mathrm{~nm}$ (azul:

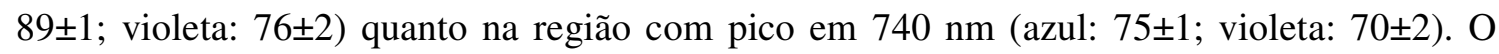
teste comprova que a luz azul é a melhor opção para excitação da fluorescência das amostras, seja para observar a região sadia ou a lesão da doença.

\subsubsection{Metodologia no processamento das imagens}

\subsubsection{Análise das imagens espectrais}

Durante os experimentos com o espectrômetro nossa necessidade era transformar um espectro com cerca de 500 pontos (540 a $800 \mathrm{~nm}$ ) em algumas figuras de mérito e autocorrelação e estudar os seus valores. Agora não há necessidade de tantas figuras de mérito, pois o número de parâmetros a ser estudado aumentou na proporção do número de pixels na imagem. Se por um lado o experimento com imagem nos oferece mais informação, este também complica a analise, pois além da resolução espectral também exploramos a resolução espacial. Ou seja, uma analise quantitativa dos dados exigiria um processamento de imagens específico, que considerasse o valor da figura de mérito e a área da lesão. É provável que somente este processamento já fosse trabalho para o doutoramento de um aluno, por isso optamos por processar as imagens capturadas de forma a obter a $\mathrm{RF} / \mathrm{FRF}$ e $\mathrm{RF} / \mathrm{FRF}_{\mathrm{n}}$ e com isso apresentar uma analise qualitativa dos resultados.

\subsubsection{Resultados}

A Figura 5.2 contém as imagens de uma folha infectada com cancro cítrico e outra com verrugose, já a Figura 5.3 contém as imagens uma folha infectada com CVC e de uma contaminada com greening. Todas essas folhas foram coletadas de plantas distintas da mesma 
variedade Laranja Pêra e representam o comportamento das demais amostras contaminadas com cancro cítrico, verrugose, CVC e greening. A exposição da CCD foi de 20 segundos e a excitação foi por luz azul com cerca de $25 \mathrm{~mW} / \mathrm{cm}^{2}$. Em geral, as amostras possuíam entre 40 e $50 \mathrm{~mm}$ de comprimento, de forma que o tempo total para aquisição do sinal foi menor que 30 minutos por folha.

Ambas as figuras estão dispostas em linhas e colunas para melhor organizar as imagens. Para cada uma das folhas, elas apresentam: a imagem digital (Figuras 5.2a, 5.2b, 5.3a e 5.3b), a imagem espectral da emissão em 690 nm (Figuras 5.2c, 5.2d, 5.3c e 5.3d) e em 740 nm (Figuras 5.2e, 5.2f, 5.3e e 5.3f), além da imagem da RF/FRF (Figuras 5.2g, 5.2h, 5.3g e 5.3h). As imagens espectrais são apresentadas em escala de cinzas enquanto as RF/FRF estão em falsas cores. Um detalhe sobre o cálculo da RF/FRF deve ser destacado. As intensidades próximas a zero, quando no denominador, implicavam uma razão tão alta que ficava fora da escala escolhida; nesses casos o valor da razão foi nulo. Esse caso ocorreu com as intensidades do fundo da imagem e na necrose.

As imagens digitais estão presentes para mostrar os sintomas visuais das amostras. As Figuras 5.2a, 5.2b e 5.3a apresentam os sintomas visuais da lesão do cancro cítrico, verrugose e CVC, respectivamente. Vê-se que todas as lesões apresentam uma região necrótica eruptiva e o tecido de tonalidade amarelada em volta da necrose. No caso do cancro a necrose está localizada em dois sítios da folha, já no caso da verrugose e da CVC a necrose está espalhada pela folha inteira. Diferente dessas, o greening não apresenta região necrótica na lesão, apenas a amarelada; o baixo contraste na Figura 5.3b revela a dificuldade de diagnóstico visual do greening.

Os resultados mostram que nas imagens espectrais em 690 nm e em 740 nm não há um sinal relevante da fluorescência emitida pelo tecido necrosado, diferente da região esverdeada e da amarelada, onde o sinal é nítido nas imagens. As imagens espectrais ainda revelam que a intensidade emitida na região sem sintomas é diferente entre as amostras. Destacamos que a emissão da amostra contaminada com cancro cítrico é maior que as das demais. Essa variação das intensidades não foi explorada como forma de diagnóstico, pois pode ser uma característica intrínseca de cada uma das folhas ou das condições ambientais onde estas residiam. 

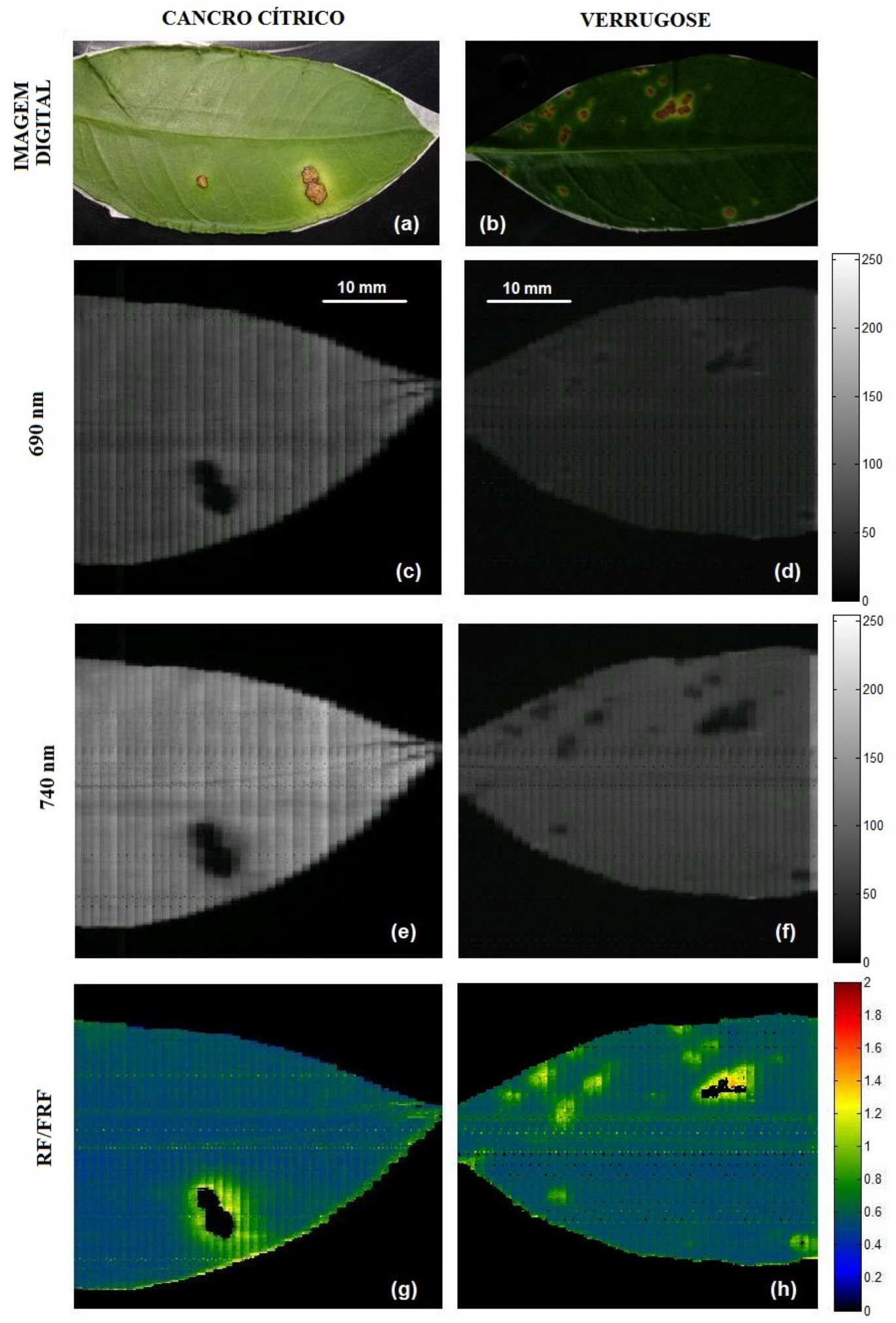

Figura 5.2 - Imagens das amostra contaminadas por cancro cítrico (coluna da esquerda) e por verrugose (coluna da direita). A primeira linha mostra imagens digitais ((a) cancro cítrico e (b) verrugose). Já a segunda ((c) e (d)) e a terceira linha ((e) e (f)) apresentam as imagens espectrais da emissão em $690 \mathrm{~nm}$ e em $740 \mathrm{~nm}$, respectivamente. A última linha ((g) e (h)) mostra a RF/FRF de cada amostra utilizada. Para essas imagens o tempo de exposição da CCD foi 20 segundos e a intensidade de iluminação $25 \mathrm{~mW} / \mathrm{cm}^{2}$. 

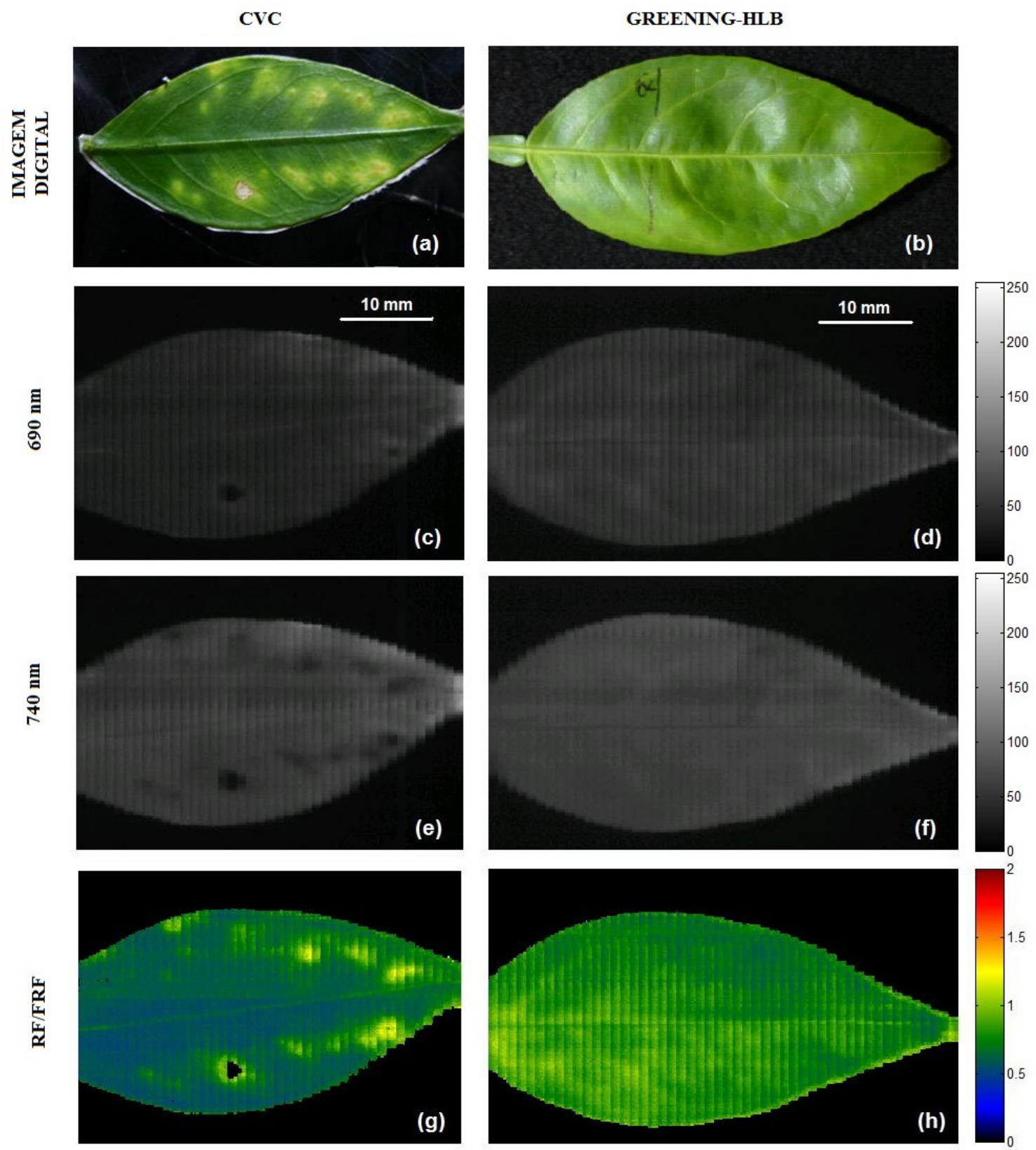

Figura 5.3 - Imagens das amostra contaminadas por CVC (coluna da esquerda) e por greening (coluna da direita). A primeira linha mostra imagens digitais ((a) CVC e (b) greening). Já a segunda ((c) e (d)) e a terceira linha ((e) e (f)) apresentam as imagens espectrais da emissão em $690 \mathrm{~nm}$ e em $740 \mathrm{~nm}$, respectivamente. A última linha ((g) e (h)) mostra a RF/FRF de cada amostra utilizada. Para essas imagens o tempo de exposição da CCD foi 20 segundos e a intensidade de iluminação $25 \mathrm{~mW} / \mathrm{cm}^{2}$.

As imagens das RF/FRF (Figuras 5.2g, 5.2h, 5.3g e 5.3h) revelam que o comportamento deste parâmetro para as amostras de cancro, verrugose e CVC são semelhantes, e que não há grandes variações detectadas. No entanto, para a amostra do greening essa variação é bem notória. O baixo contraste observado na sua imagem digital (Figura 5.3b) pode ser observado na RF/FRF (Figura 5.3h) e pode ser usado para discriminar o greening. 
Essa observação implica em outro dado. As amostras de cancro cítrico, verrugose e CVC apresentam valores semelhantes na região sadia da folha, variando entre 0.5 e 0.7 . Isso mostra que o comportamento da RF/FRF independe da variedade da planta. Mais uma vez o greening é um caso particular, pois seus sintomas não ficam confinados em sítios e se espalham por toda a folha. Esse grupo de valores da RF/FRF concorda com os valores obtidos das folhas sadias na espectroscopia no campo (entre 0.48 e 0.88 ) e confirma a reprodução da técnica.
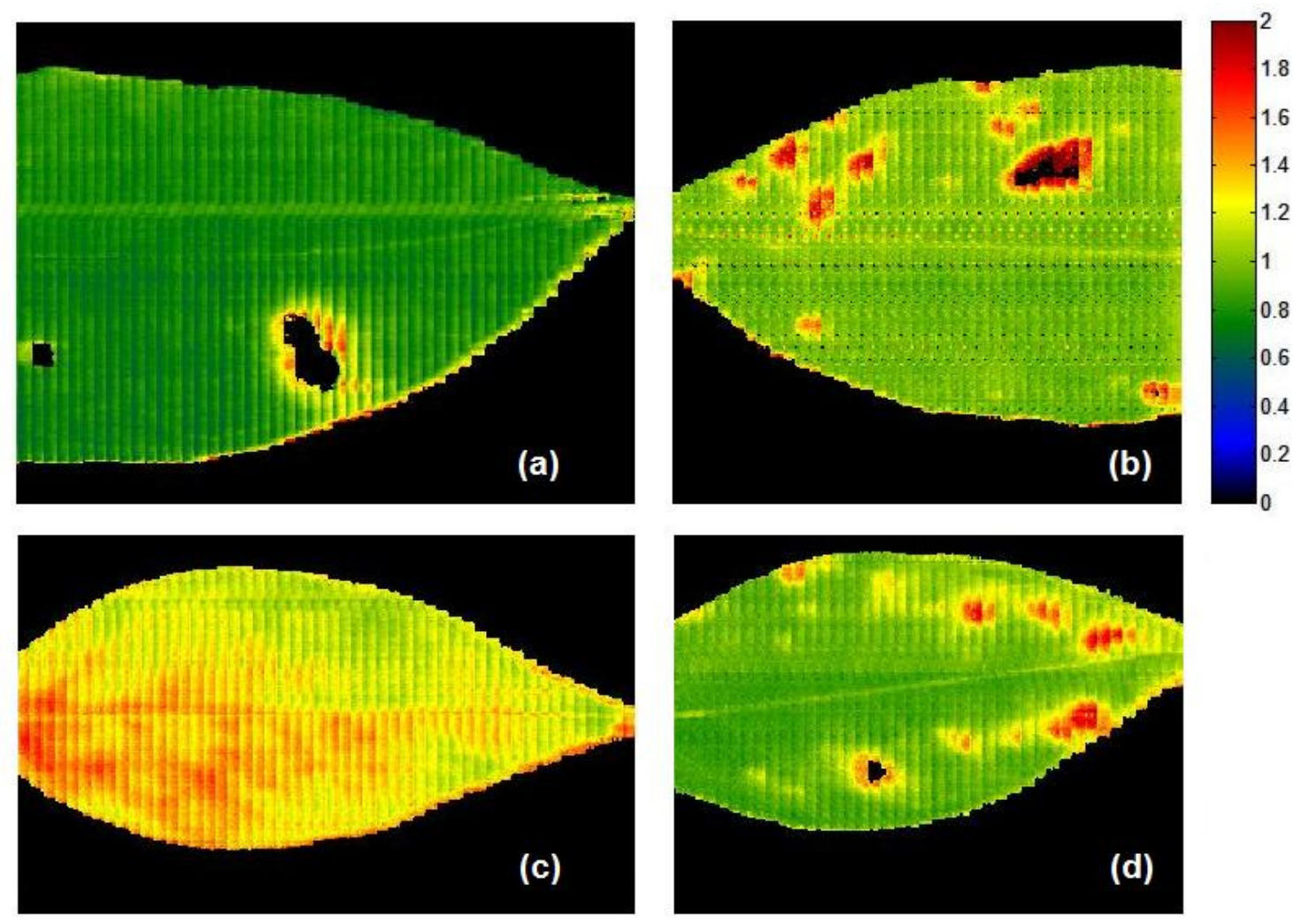

Figura 5.4 - Imagens da RF/FRF (normalizada pelos dados de folhas sadias). (a) Amostra contaminada por cancro cítrico. (b) Amostra contaminada por verrugose. (c) Amostra contaminada por greening. (d) Amostra contaminada por CVC.

Em seguida apresentamos os resultados das RF/FRF normalizadas na Figura 5.4. Para o cálculo dessas imagens a intensidade média da RF/FRF das folhas sadias foi $0.67 \pm 0.03$ para o cancro cítrico, $0.59 \pm 0.02$ para a verrugose, $0.57 \pm 0.03$ para o CVC e $0.62 \pm 0.01$ para o greening. $\mathrm{O}$ contraste revelado nas imagens de $\mathrm{RF} / \mathrm{FRF}_{\mathrm{n}}$ mostra as particularidades de cada lesão. Pode-se perceber que em torno da necrose do cancro cítrico (Figura 5.4a) há uma prevalência dos valores de $\mathrm{RF} / \mathrm{FRF}_{\mathrm{n}}$ entre 1.1 e 1.3 , onde se destaca a cor amarela. Já as demais lesões 
apresentam valores desde 1.1 a 1.6. Em especial destacamos a lesão do greening (Figura 5.4c) onde o contraste revela a dispersão da lesão em toda a folha.

As imagens do espectrógrafo nos possibilitavam observar a emissão das amostras em outras bandas espectrais, como na região em $615 \mathrm{~nm}$. As imagens espectrais da emissão nesta região são mostradas em falsas cores na Figura 5.5, e revelam uma variação característica de cada lesão. Neste grupo a Figura 5.5a representa a emissão da amostra com cancro cítrico, a Figura 5.5b representa a com verrugose, a Figura 5.5c é a amostra com greening e a Figura $5.5 \mathrm{~d}$ é a amostra contaminada por CVC. Este resultado foi inédito e inesperado. O valor das intensidades mostra que o sinal emitido nessa região é baixo quando usamos essa metodologia, pois a escala de intensidades varia entre 0 e 255. Mesmo assim há um contraste perceptível se desejarmos discriminar a lesão da verrugose das demais. As imagens ainda mostram que a intensidade detectada na região sadia se assemelha à do suporte onde as folhas estão posicionadas e por isso se confunde com o fundo da imagem.
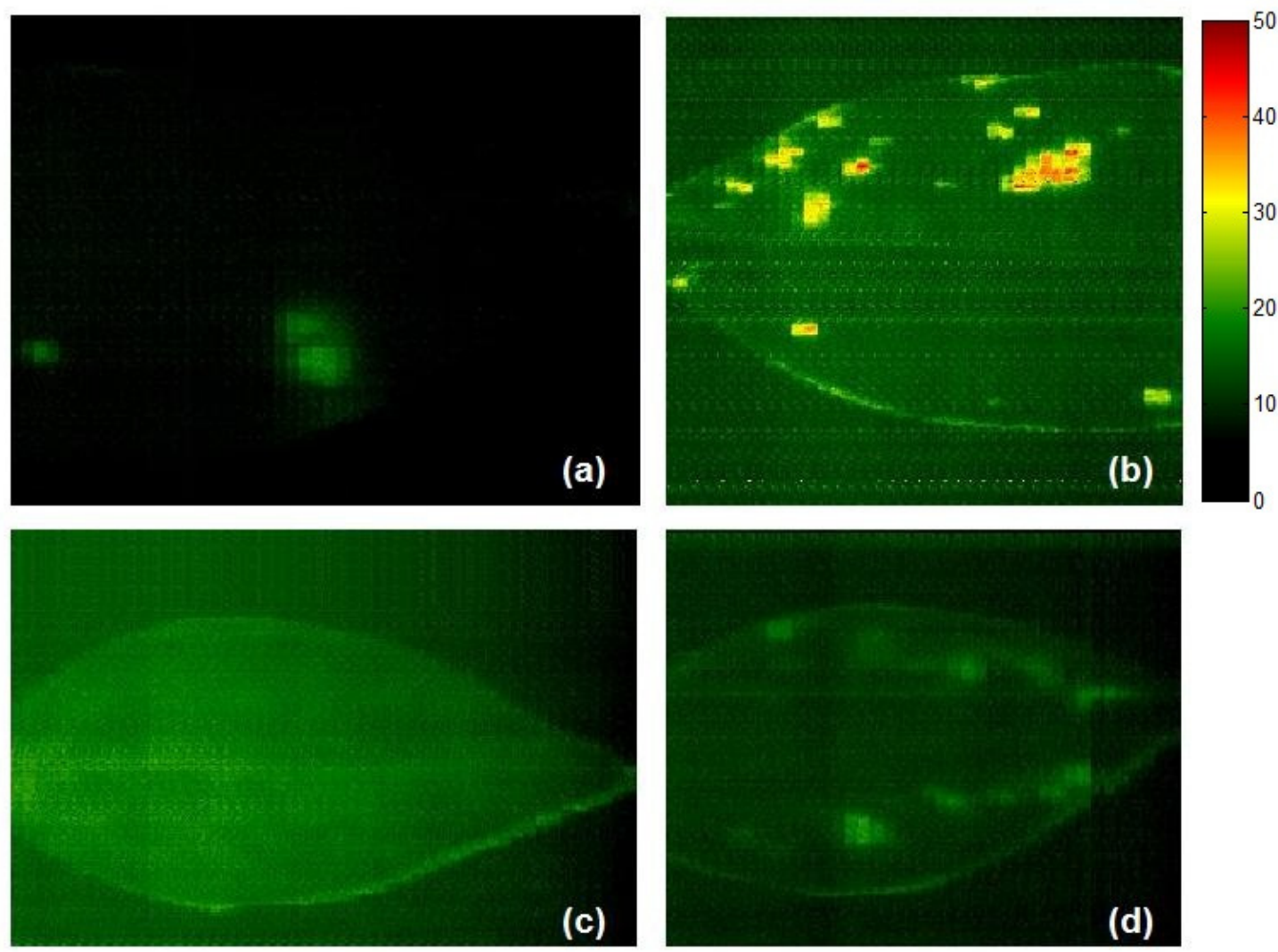

Figura 5.5 - Imagens espectrais da fluorescência emitida em $615 \mathrm{~nm}$. (a) Amostra contaminada por cancro cítrico. (b) Amostra contaminada por verrugose. (c) Amostra contaminada por greening. (d) Amostra contaminada por CVC. Para essas imagens o tempo de exposição da CCD foi 20 segundos e a intensidade de iluminação $25 \mathrm{~mW} / \mathrm{cm}^{2}$. 
Comparando os valores detectados, vemos que a emissão da lesão do cancro cítrico (Figura 5.5a), do greening (Figura 5.5c) e da CVC (Figura 5.5d) varia entre 20 e 28, enquanto que a lesão da verrugose (Figura 5.5b) varia entre 30 e 40, confirmando que nesta banda espectral a lesão da verrugose emite mais fluorescência que as demais doenças estudadas. Esse dado se apresenta como uma possibilidade de nova metodologia para a discriminação da verrugose. Acreditamos que a fluorescência emitida pelas lesões na região espectral em $615 \mathrm{~nm}$ seja devido à presença dos agentes patogênicos das doenças. É fato que a emissão da fluorescência nessa banda não é característica das clorofilas, pois a emissão da região esverdeada comprova isso. Além disso, a literatura científica reporta que diversos agentes patogênicos produzem derivados de porfirinas, e que essas biomoléculas são responsáveis tanto pela absorção de radiação na região do UV-azul quanto pela emissão de fluorescência na região de $615 \pm 10$ nm (24-25,63-64,68). Uma análise detalhada da emissão da fluorescência em função dos agentes patogênicos ou da concentração das biomoléculas existentes foge dos nossos objetivos iniciais.

\subsection{EXPERIMENTOS COM O SISTEMA COM UMA RODA DE FILTROS}

Desenvolver e aplicar o sistema com o espectrógrafo nos deu experiência sobre as imagens espectrais. Infelizmente percebemos que o SIE não era o melhor sistema para dar continuação ao nosso trabalho, pois para levá-lo ao campo seriam necessárias adaptações que tomariam tempo e dedicação. Ao invés do SIE, optamos por investir em um sistema com roda de filtros, que seria mais versátil e fácil de operar.

\subsubsection{Metodologia}

Nesta nova metodologia experimental apenas o comprimento de onda de excitação $(470 \pm 10 \mathrm{~nm})$ e a intensidade de iluminação sobre a amostra $\left(25 \mathrm{~mW} / \mathrm{cm}^{2}\right)$ foram utilizados nos experimentos com o SIE. As amostras foram coletadas no município de Guararapes (oeste paulista), a $360 \mathrm{Km}$ de São Carlos. Nesta viagem 54 amostras com sintomas e 41 amostras 
sadias foram coletadas de um total de 19 plantas. Coletamos amostras das variedades cítricas Limão Cravo, Limão Galego, Cidra, Tangerina e Laranja Doce para as doenças cancro cítrico e verrugose. Porém os tipos de amostras foram folhas, superfície de frutos e ramos das árvores. Nosso conjunto de amostras final apresentou 83 folhas (65 com cancro, 8 com verrugose, 10 com sintomas de ambas as doenças), 9 frutos ( 7 com cancro e 2 com verrugose) e 2 ramos com cancro. A análise das imagens foi realizada da mesma maneira que nos experimentos com o SIE. Desta vez tínhamos quatro imagens espectrais, mas optamos por realizar apenas a $\mathrm{RF} / \mathrm{FRF}$ e a RF/FRF .

\subsubsection{Resultados}

Iniciamos esta secção mostrando as imagens espectrais de duas folhas, uma contaminada por cancro cítrico (Figura 5.6) e a outra contaminada por verrugose (Figura 5.7). Mais uma vez as figuras apresentam imagens sobre os sintomas visuais na folha destacando a amostra inteira (Figuras 5.6a e 5.7a) e o detalhe sobre as lesões estudadas (Figuras 5.6b e 5.7b). $\mathrm{Na}$ sequiência as imagens espectrais são apresentadas em tons de cinza, destacando a imagem da emissão em 570 nm (Figuras 5.6c e 5.7c), em 610 nm (Figuras 5.6d e 5.7d), em $690 \mathrm{~nm}$ (Figuras 5.6e e 5.7e) e em $740 \mathrm{~nm}$ (Figuras 5.6f e 5.7f). O ganho da câmera utilizado na captura das imagens espectrais do cancro cítrico foi $10 \mathrm{~dB}$ e da verrugose foi $7 \mathrm{~dB}$; por isso, para comparar os resultados das amostras foi necessário corrigir a intensidade detectada utilizando a curva de calibração do ganho da câmera.

A partir das imagens espectrais, observamos na região de $570 \mathrm{~nm}$ (Figuras 5.6c e 5.7c) e de $610 \mathrm{~nm}$ (Figuras 5.6d e 5.7d) a necrose emite mais fluorescência que a região sadia. Esse comportamento espectral é contrário ao da emissão nas regiões em $690 \mathrm{~nm}$ e $740 \mathrm{~nm}$, onde o maior sinal é detectado onde há clorofilas.

Em ambas as amostras a emissão em 570 nm é maior que em $610 \mathrm{~nm}$. Para o cancro a fluorescência emitida pelas necroses da Figura 5.6c atinge intensidades em torno de 158, enquanto que na Figura 5.6d as intensidades estão em torno de 97. Essa observação vale para a verrugose, mas a diferença entre as intensidades não é tão significativa; a fluorescência emitida em $570 \mathrm{~nm}$ (Figura 5.7c) atinge 76 de intensidade, enquanto a emissão em $610 \mathrm{~nm}$ (Figura 5.7d) atinge 69 de intensidade. 
Ao corrigir as intensidades das imagens espectrais da verrugose (ganho de $7 \mathrm{~dB}$ ) para comparar com as intensidades do cancro (ganho de 10dB) o fator de correção utilizado é 1.43, o qual implica intensidade em torno de 110 na região de $570 \mathrm{~nm}$ e de 97 na região de $610 \mathrm{~nm}$. Esses dados revelam a semelhança entre a emissão das necroses do cancro e da verrugose na região de $610 \mathrm{~nm}$ (97 de intensidade), diferente das imagens do SIE (Figura 5.6) que observavam mais sinal por parte da verrugose.
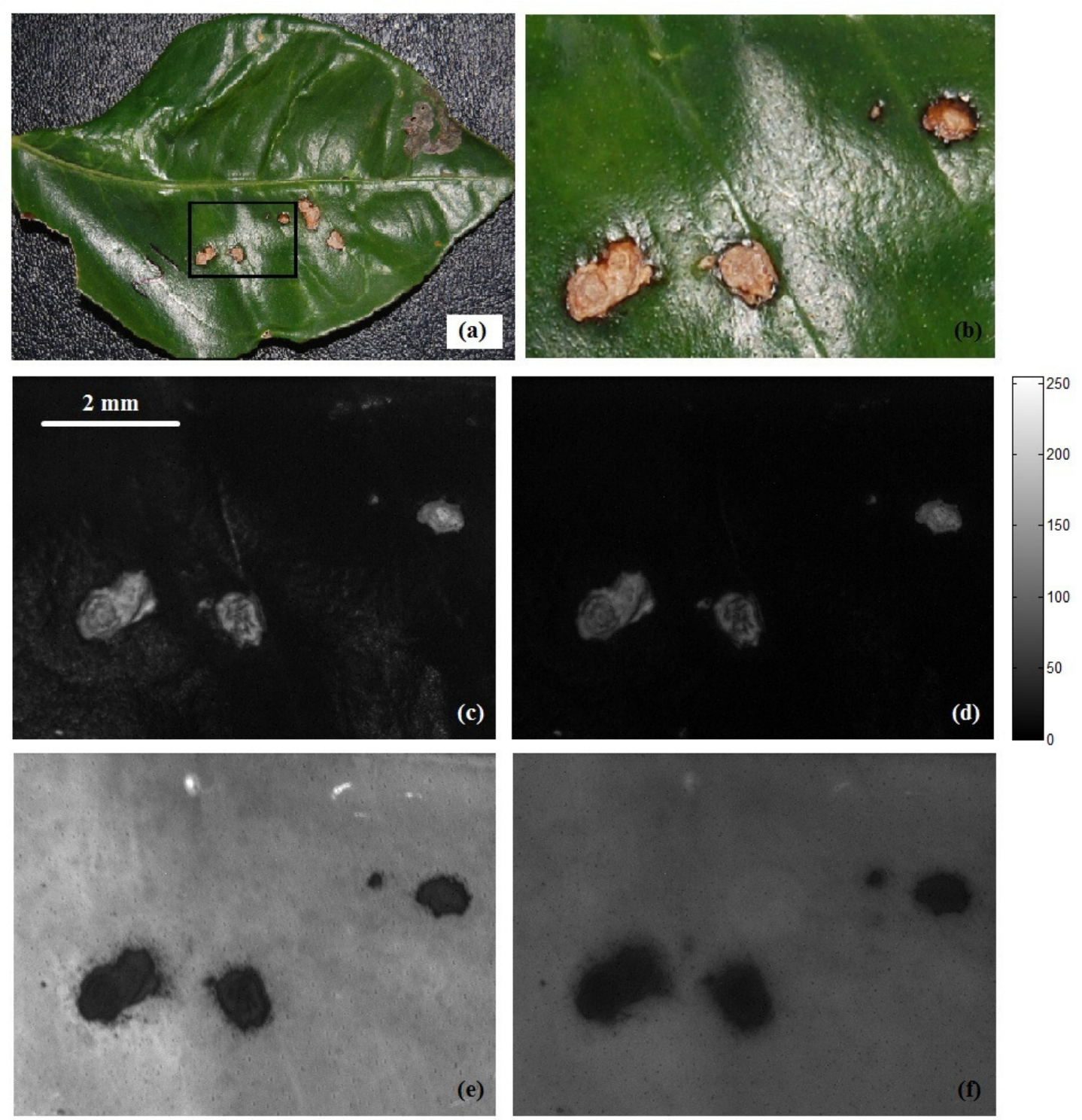

Figura 5.6 - (a) Imagens de uma amostra contaminada com cancro cítrico. (b) Destaque da região espacial da folha em que as imagens espectrais foram capturadas. Na seqüência estão as imagens espectrais capturadas pelo SIF em: (c) $570 \mathrm{~nm}$, (d) $610 \mathrm{~nm}$, (e) $690 \mathrm{~nm}$ e (f) $740 \mathrm{~nm}$. Para essas imagens o tempo de exposição da CCD foi 10 segundos, $o$ ganho da detecção foi $10 \mathrm{~dB}$ e a intensidade de iluminação foi 25 $\mathbf{m W} / \mathrm{cm}^{2}$. 

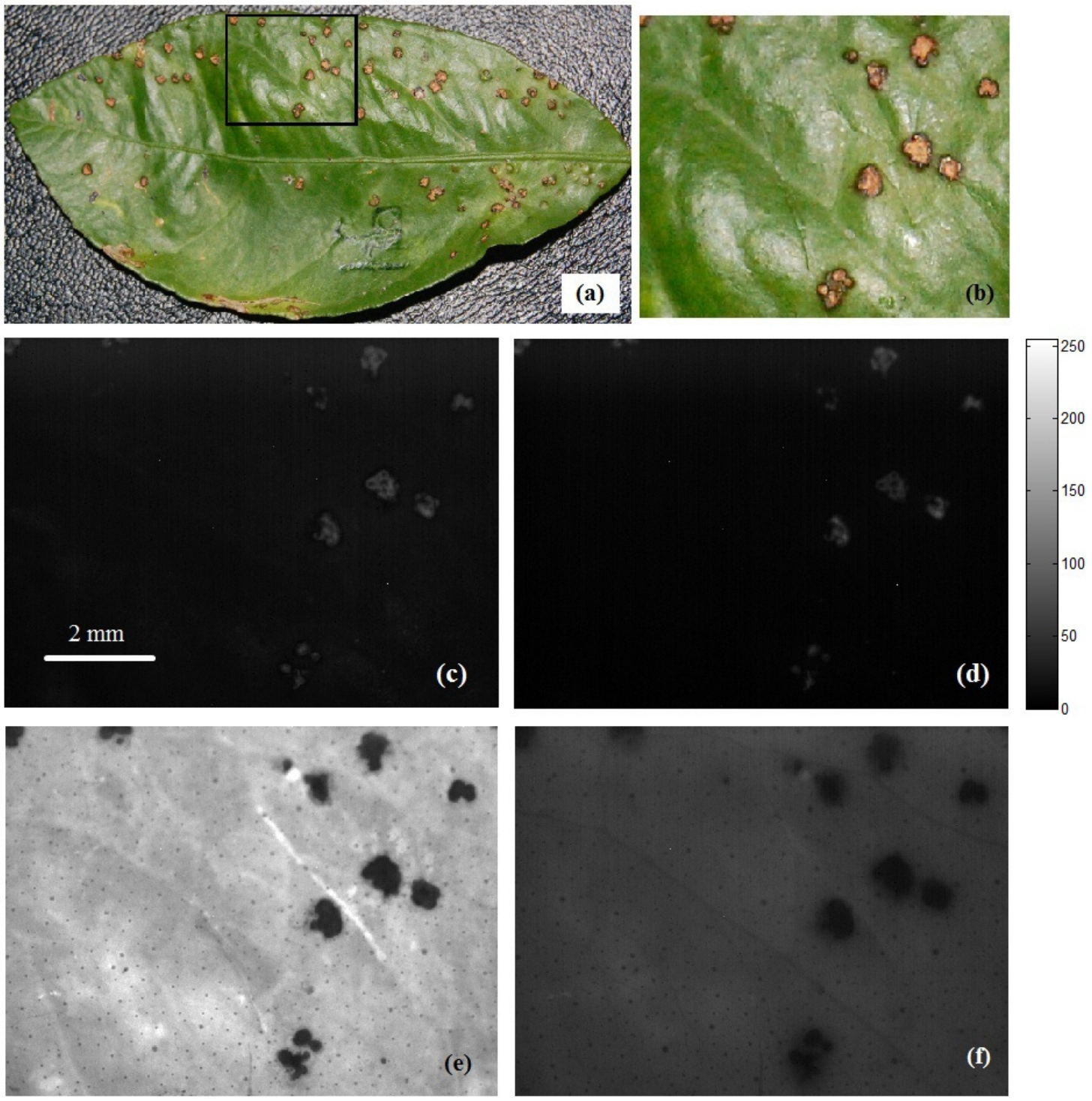

Figura 5.7 - (a) Imagens de uma amostra contaminada com verrugose. (b) Destaque da região espacial da folha em que as imagens espectrais foram capturadas. Na sequiência estão as imagens espectrais capturadas pelo SIF em: (c) $570 \mathrm{~nm}$, (d) $610 \mathrm{~nm}$, (e) $690 \mathrm{~nm}$ e (f) $740 \mathrm{~nm}$. Para essas imagens o tempo de exposição da CCD foi 10 segundos, o ganho da detecção foi $7 \mathrm{~dB}$ e a intensidade de iluminação foi 25 $\mathrm{mW} / \mathrm{cm}^{2}$.

Essa diferença entre as imagens espectrais dos dois sistemas pode estar associada ao tipo de lesão das amostras, uma vez que as lesões da Figura 5.2 apresentam a região amarelada em volta das necroses e as lesões da Figura 5.6 e 5.7 não apresentam a região amarelada. Outro fator pode ser a sensibilidade dos sensores das câmeras, as quais são diferentes entre si.

As imagens da emissão em $690 \mathrm{~nm}$ (Figuras 5.6e e 5.7e) e $740 \mathrm{~nm}$ (Figuras 5.6f e 5.7f) comprovam que a região das amostras onde não há necrose emite mais fluorescência na região de $690 \mathrm{~nm}$ que na região de $740 \mathrm{~nm}$, revelando para o cancro uma média de intensida- 
de de $140 \pm 1$ (Figura 5.6e) e 74 \pm 1 (Figura 5.6f) enquanto que a verrugose apresenta uma mé-

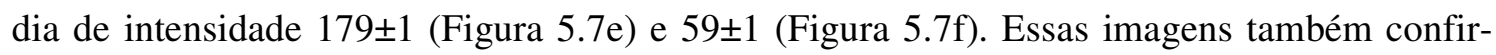
mam que, para ambas as amostras, a emissão de fluorescência pela necrose é baixa e a maior intensidade detectada atinge 51de intensidade.

Na sequiência, apresentamos na Figura 5.8 a RF/FRF e a RF/FRF $F_{n}$ das amostras estudadas. Para a $\mathrm{RF} / \mathrm{FRF}_{\mathrm{n}}$ foi necessária a $\mathrm{RF} / \mathrm{FRF}$ das folhas sadias as quais revelaram valores de $1.73 \pm 0.02$ para o cancro cítrico e $2.37 \pm 0.04$ para a verrugose. Esses valores da RF/FRF das folhas sadias não coincidem com os valores calculados com o SIE. Acreditamos que a principal causa seja a correção das imagens pela curva de detecção do sensor e pela transmitância dos filtros ópticos. Três folhas sadias foram utilizadas em cada grupo para calcular a RF/FRF.

CANCRO CÍTRICO
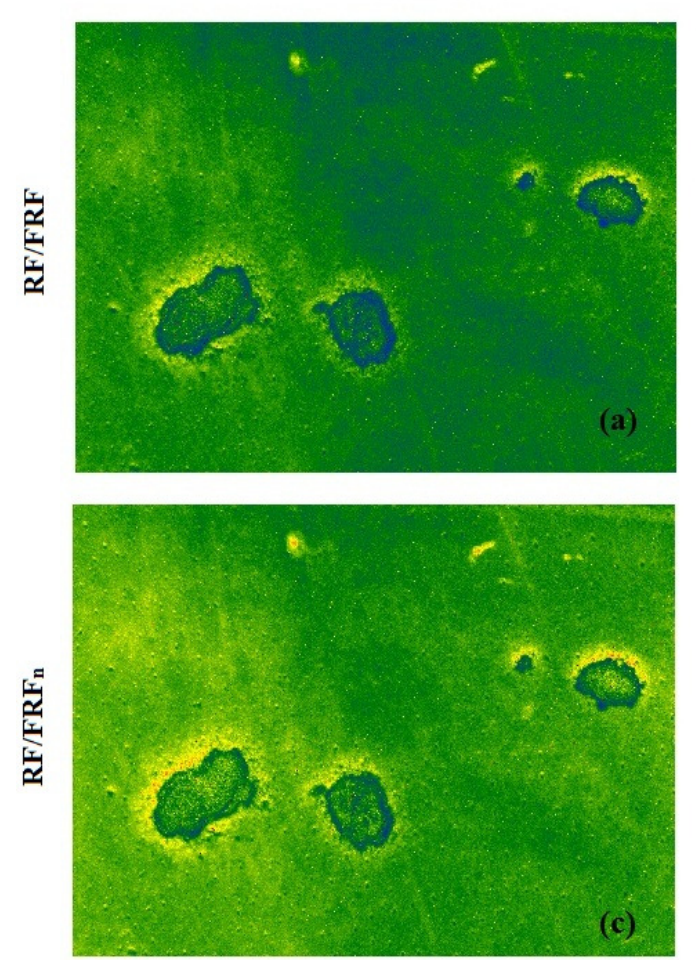

\section{VERRUGOSE}
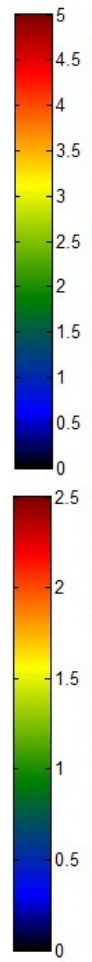
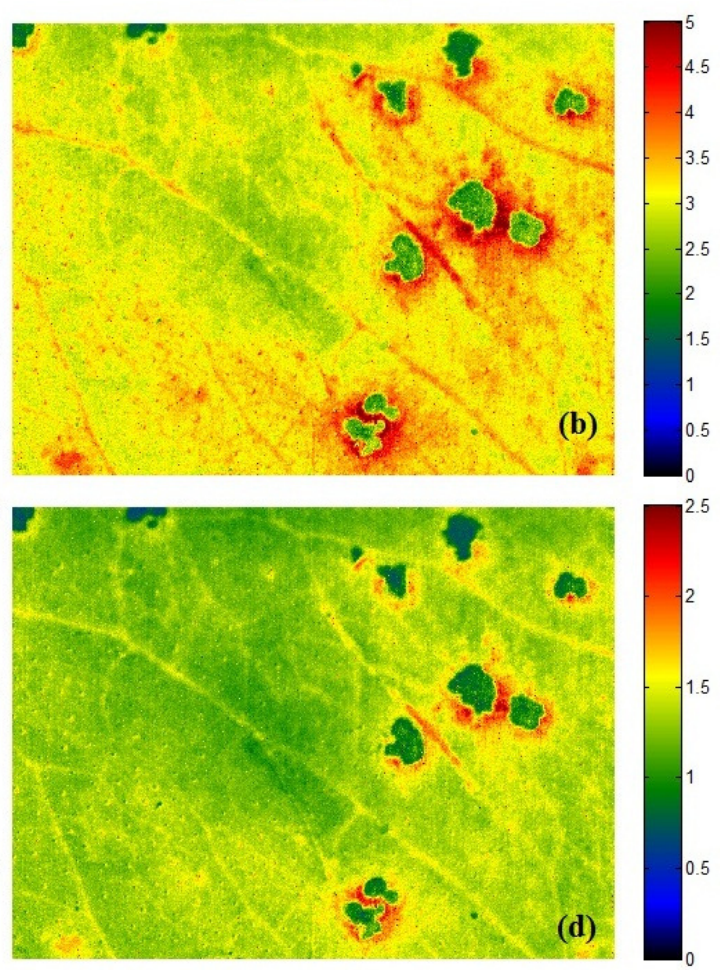

Figura 5.8 - Imagens da RF/FRF (linha superior) e da $R F / F R F_{n}$ (linha inferior) das amostras estudadas. Na primeira coluna estão as razões da amostra contaminada por cancro cítrico, enquanto a segunda coluna apresenta as razões da amostra contaminada por verrugose. Para formar as imagens das amostras sintomáticas o tempo de exposição da CCD foi 10 segundos, o ganho da deteç̧ão foi $10 \mathrm{~dB}$ para a amostra com cancro e $7 \mathrm{~dB}$ para a amostra com verrugose e a intensidade de iluminação foi $25 \mathrm{~mW} / \mathrm{cm}^{2}$. Para formar as imagens das amostras sadias o tempo de exposição da CCD foi 10 segundos, o ganho da deteç̧ão foi $10 \mathrm{~dB}$ para todas as amostras e a intensidade de iluminação foi $25 \mathrm{~mW} / \mathrm{cm}^{2}$.

Uma observação deve ser feita. Nas RF/FRF do SIE havia muitos valores fora da escala devido à baixa intensidade emitida pelo fundo da imagem e pela necrose nas imagens em 
$740 \mathrm{~nm}$. Nas imagens do SIF não há a presença do fundo, além disso a câmera do SIF é mais sensível que a câmera do SIE e por isso as intensidades detectadas na região da necrose são baixas, mas não nulas.

Destacamos as regiões em volta das necroses. Para o cancro, nessa região a RF/FRF apresenta intensidades entre 2.40 e 3.02 (tons verde-amarelados na Figura 5.8a) e a RF/FRF apresenta intensidades entre 1.39 e 1.73 (tons verde-amarelados na Figura 5.8c) enquanto que para a verrugose a região apresenta RF/FRF com valores entre 3.70 e 5 (tons laranjavermelhos na Figura 5.8b) e a $\mathrm{RF} / \mathrm{FRF}_{\mathrm{n}}$ apresenta valores entre 1.56 e 2.33 (tons amarelovermelhos na Figura 5.8d).

Outra observação relevante é a distribuição das intensidades na região espacial da necrose. Podemos observar que as imagens das necroses do cancro cítrico apresentam uma borda na cor azul que faz interface com a região sadia (valores entre 1.1 e 1.4 para a RF/FRF e entre 0.65 e 0.8 na $\mathrm{RF} / \mathrm{FRF}_{\mathrm{n}}$ ). Exceto na borda, a tonalidade dos tecidos apresenta prevalência dos tons de verde e amarelo.

Já nas imagens das necroses da verrugose esse comportamento não acontece. A distribuição de cores na área da necrose é uniforme e não há a presença da borda com prevalência dos tons em verde e amarelo na RF/FRF (valores entre 1.8 e 3.0) e dos tons de azul e verde na $\mathrm{RF} / \mathrm{FRF}_{\mathrm{n}}$ (valores entre 0.76 e 1.26).

Finalizando, apresentamos na Figura 5.9 as imagens espectrais de outras amostras encontradas no campo, diferente de folhas. Nesse grupo estão os frutos e os ramos, amostras onde também surgem lesões das doenças. Neste conjunto de dados as imagens são apresentadas na forma de uma matriz com 5 linhas e três colunas. As linhas apresentam a banda espectral de detecção da fluorescência; seguindo a ordem crescente das linhas estão as bandas em $570 \mathrm{~nm}, 610 \mathrm{~nm}, 690 \mathrm{~nm}$ e $740 \mathrm{~nm}$, a última linha contém as RF/FRF das amostras.

As colunas separam as amostras; nesta figura apresentamos uma lesão de cancro cítrico em um fruto da espécie Limão Galego (coluna 1), uma lesão de verrugose no fruto da espécie Limão Cravo (coluna 2) e uma lesão de cancro cítrico no ramo de uma planta da espécie Cidra (coluna 3). Todas as imagens foram capturadas usando $10 \mathrm{~dB}$ de ganho da câmera. Nosso intuito com essas imagens é demonstrar que o SIF é capaz de estudar frutos e ramos. Por esta razão nos limitaremos as imagens de fluorescência e RF/FRF. Desta forma, nosso sistema pode ser aplicado em folhas, frutos e ramos. 

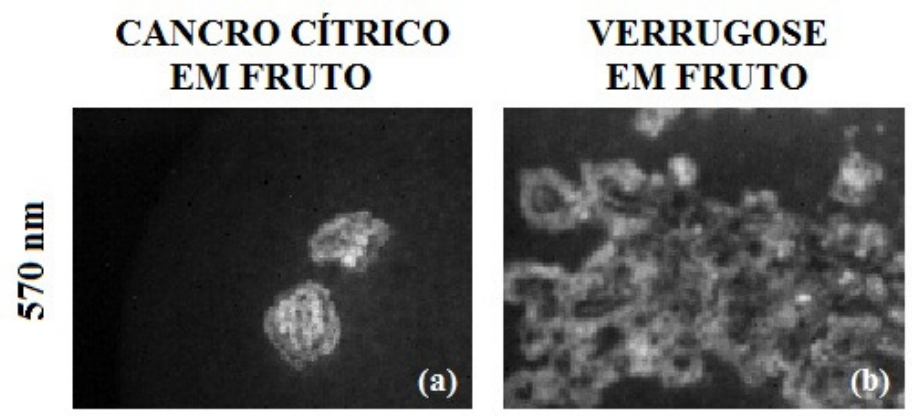

\section{CANCRO CÍTRICO \\ EM RAMO}
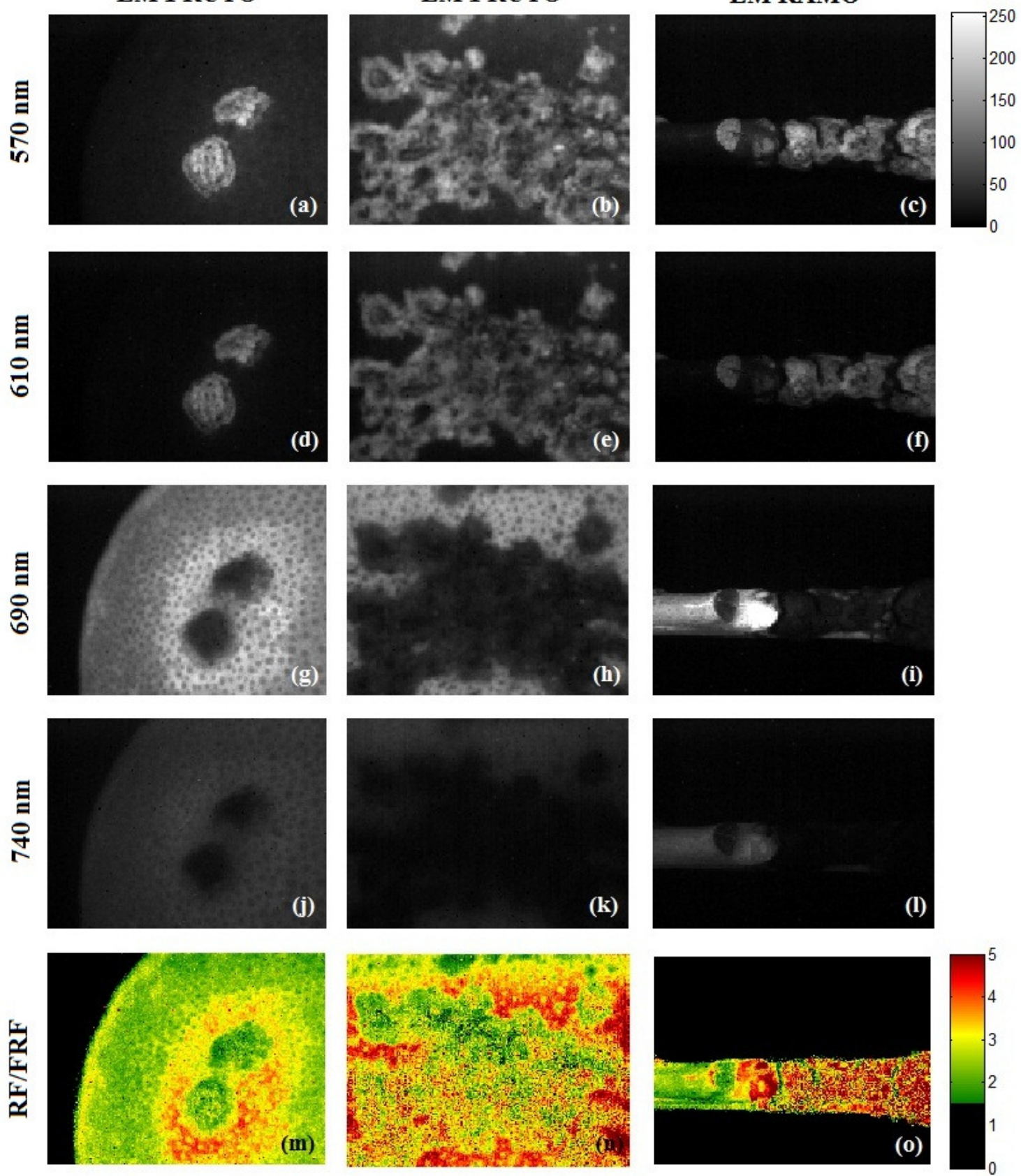

Figura 5.9 - Imagens do SIF para amostras não-usuais encontradas no campo. A primeira coluna se refere a um limão galego contaminado por cancro cítrico. A segunda coluna se refere a um limão cravo contaminado por verrugose. A terceira coluna se refere a um ramo de cidra contaminado por cancro cítrico. As linhas mostram as imagens espectrais em $570 \mathrm{~nm}$ (primeira linha), $610 \mathrm{~nm}$ (segunda linha), 690 nm (terceira linha) e $740 \mathrm{~nm}$ (quarta linha); a quinta linha mostra as RF/FRF das amostras.

As imagens revelam que a emissão de frutos e ramos se assemelha com a emissão de folhas, pois as necroses continuam a fluorescer mais na região de $570 \mathrm{~nm}$ e $610 \mathrm{~nm}$ enquanto que na região além da necrose há mais emissão na região espectral de 690 nm e 740 nm. 
Além disso, destacamos que a Figura 5.9g (fruto com cancro cítrico emitindo em 690 $\mathrm{nm}$ ) e a Figura 5.9h (fruto com verrugose emitindo em $690 \mathrm{~nm}$ ) apresentam informações sobre a característica da superfície dos frutos, detalhando o perfil de emissão de possíveis estruturas porosas na casca do fruto; a emissão de tais estruturas pode ser estudada e correlacionada com o processo de amadurecimento ou adoecimento dos frutos.

\subsection{EXPERIMENTO QUANTITATIVO UTILIZANDO SISTEMA COM UMA RODA DE FILTROS - CORRELAÇÃO ENTRE A FLUORESCÊNCIA EMITIDA E A TAXA DE PRODUÇÃO DE ETILENO PELAS FOLHAS CÍTRICAS}

Como já foi explicado, até o momento nossos estudos foram apenas qualitativos, visto que a resolução espacial do sistema de imagem adiciona um grau extra de complicação na análise. Para demonstrar que nosso sistema também é capaz de realizar medidas quantitativas resolvemos estudar um problema onde toda a informação pode ser resumida em um único parâmetro. Este problema é a formação de etileno após a folha ter sido destacada da planta.

Este estudo é baseado no artigo publicado por E. Katz e co-autores em 2005 (37) onde foi demonstrado que as folhas cítricas possuem um comportamento climatérico ao serem destacadas das árvores originais, apesar da literatura científica tratar as folhas como nãoclimatéricas.

O climatério é um estágio do processo de amadurecimento das frutas, seja ainda na planta original ou depois do destacamento, e está fortemente relacionado com a produção de etileno pelo fruto ou folha. O etileno é um dos principais hormônios da planta que durante o seu ciclo de vida influencia diretamente a germinação de sementes, a diferenciação celular, o amadurecimento dos frutos, o processo de senescência além de ser uma das principais alternativas para monitoramento da resposta da planta a estresses bióticos e abióticos (37).

Neste estudo o autor utilizou folhas de plantas da espécie laranja valência que foram colhidas das plantas jovens (aproximadamente 2 meses de idade) e maduras (aproximadamente 8 meses de idade) e mantidas no escuro a $25^{\circ} \mathrm{C}$ e $100 \%$ de umidade relativa. A quantidade emitida de etileno foi aferida diariamente durante 12 dias seguidos. Para a medição as amostras eram alojadas e mantidas por duas horas dentro de tubos de 18 ou $6 \mathrm{ml}$ selados. Amostras de $1 \mathrm{ml}$ do ar eram retiradas dos tubos e inseridas dentro de um cromatógrafo de gás Varian 
3300 (Varian, Inc., EUA) equipado com uma coluna de alumina a $100{ }^{\circ} \mathrm{C}$ e um detector de ionização de chama a $120^{\circ} \mathrm{C}$. A medida da concentração do etileno se baseou em uma concentração conhecida de etileno que foi injetada dentro do cromatógrafo e tomada como referência de calibração. Esse padrão foi utilizado antes e depois da análise.

Este experimento nos interessou por tratar de uma técnica para avaliação do processo de senescência da folha destacada da planta-mãe, por utilizar folhas cítricas como amostra e por necessitar de técnicas e equipamentos de medida muito sensíveis às variações das condições onde o equipamento está alocado, de forma que o estudo só pode ser realizado no laboratório. Devemos destacar que a realização deste experimento é complexa e requer equipamentos sofisticados. Isso nos motivou utilizar nosso sistema, o qual é muito mais versátil e fácil de operar, na tentativa de conseguirmos obter alguma informação neste processo.

Os resultados do artigo que mais nos interessaram são revelados na Figura 5.10. Apresentamos os dados originais para manter a fidelidade com o estudo. Os gráficos da Figura 5.10 mostram a medida da concentração de etileno emitido pelas folhas em função do tempo após a sua colheita. Eles apresentam a emissão de etileno por parte das amostras na presença de ar (triângulo aberto) e na presença de etileno (triângulo preenchido) tanto para plantas jovens (Figura 5.10a) quanto para plantas maduras (Figura 5.10b); cada ponto apresenta a média e o erro padrão da emissão de cinco amostras.

Os gráficos indicam que as folhas de plantas cítricas apresentam dois sistemas distintos com comportamento climatérico. O primeiro ocorre em amostras na presença de etileno no ambiente (triangulo preenchido) e se caracteriza por apresentar uma baixa emissão de etileno até o segundo dia depois da colheita, um pico de emissão de etileno no quarto dia e depois a emissão de etileno volta a diminuir; a partir do sétimo dia a emissão não é mais significativa.

O segundo sistema ocorre com as amostras em ambiente aéreo (triângulo aberto) e apresenta uma baixa taxa de emissão de etileno até o sexto dia para folhas jovens e até o quinto dia para folhas maduras. A partir desta data a taxa de emissão de etileno cresce significativamente e atinge um pico de emissão no nono dia após a colheita. Em seguida a taxa volta a diminuir até o $12^{\circ}$ dia. Segundo os dados, as folhas jovens ainda apresentaram um novo pico de emissão no $10^{\circ}$ dia.

No nosso experimento utilizamos 10 folhas de laranjeiras sadias e adultas (mais de 2 anos de idade) da variedade valência. Elas foram colhidas em uma fazenda comercial na vizinhança de São Carlos e trazidas ao laboratório do IFSC para realização do estudo. As amostras foram armazenadas em uma caixa escura, a $25{ }^{\circ} \mathrm{C}$ e $100 \%$ de umidade relativa, como no 
experimento do Klatz. Em cada amostra foi marcada a área da folha em que seriam feitas as imagens.

(A)

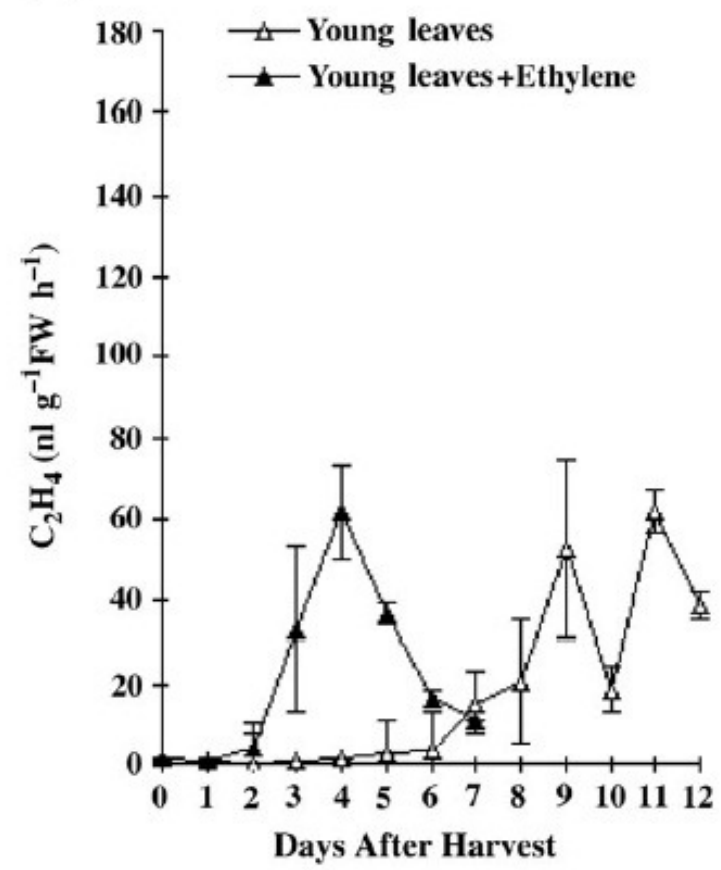

(B)

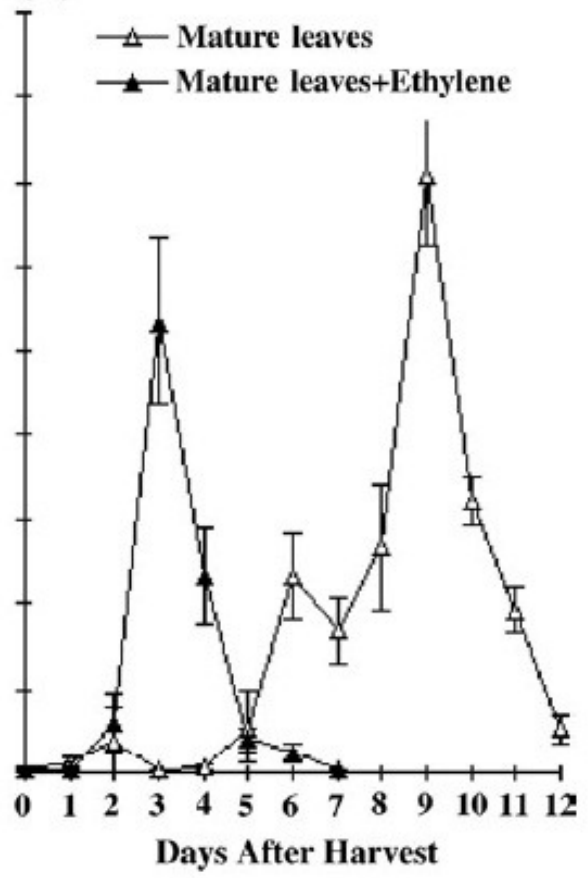

Figura 5.10 - Resultados publicados por E. Katz e co-autores sobre a emissão de etileno por folhas de laranja valência em função do tempo de colheita das folhas. (A) Perfil da emissão do etileno para folhas jovens com os grupos em ambiente aéreo (triângulo aberto) e na presença de etileno (triângulo preenchido). (B) Perfil da emissão do etileno para folhas maduras com os grupos em ambiente aéreo (triângulo aberto) e na presença de etileno (triângulo preenchido). Fonte: KATZ, E. et al. The climactericlike behaviour of young, mature and wounded citrus leaves. Journal of Experimental Botany, v. 56, n. 415, pp. 1359-1367, 2005.

Como o SIF foi utilizado, dispúnhamos das imagens espectrais em 570, 610, 690 e 740 nm. Assim, estudamos a RF/FRF das amostras além de uma razão R1 que relaciona a imagem espectral em $570 \mathrm{~nm}$ pela em $690 \mathrm{~nm}$. Cada ponto do gráfico apresenta o valor médio e o desvio padrão da intensidade média detectada em RF/FRF e em R1. A intensidade média de cada imagem é média dos valores presentes na imagem; como o número de pixels é alto a variância percentual do dado é baixa. O resultado da variação temporal da RF/FRF de uma das dez amostras é mostrado na Figura 5.11. Ela mostra doze imagens da RF/FRF, dispostas em ordem crescente com o dia de coleta (a Figura 5.11a se refere ao dia 1 e a Figura 5.111 se refere ao dia 12). Para essa amostra, o valor médio da RF/FRF chega a duplicar durante os 12 dias. 

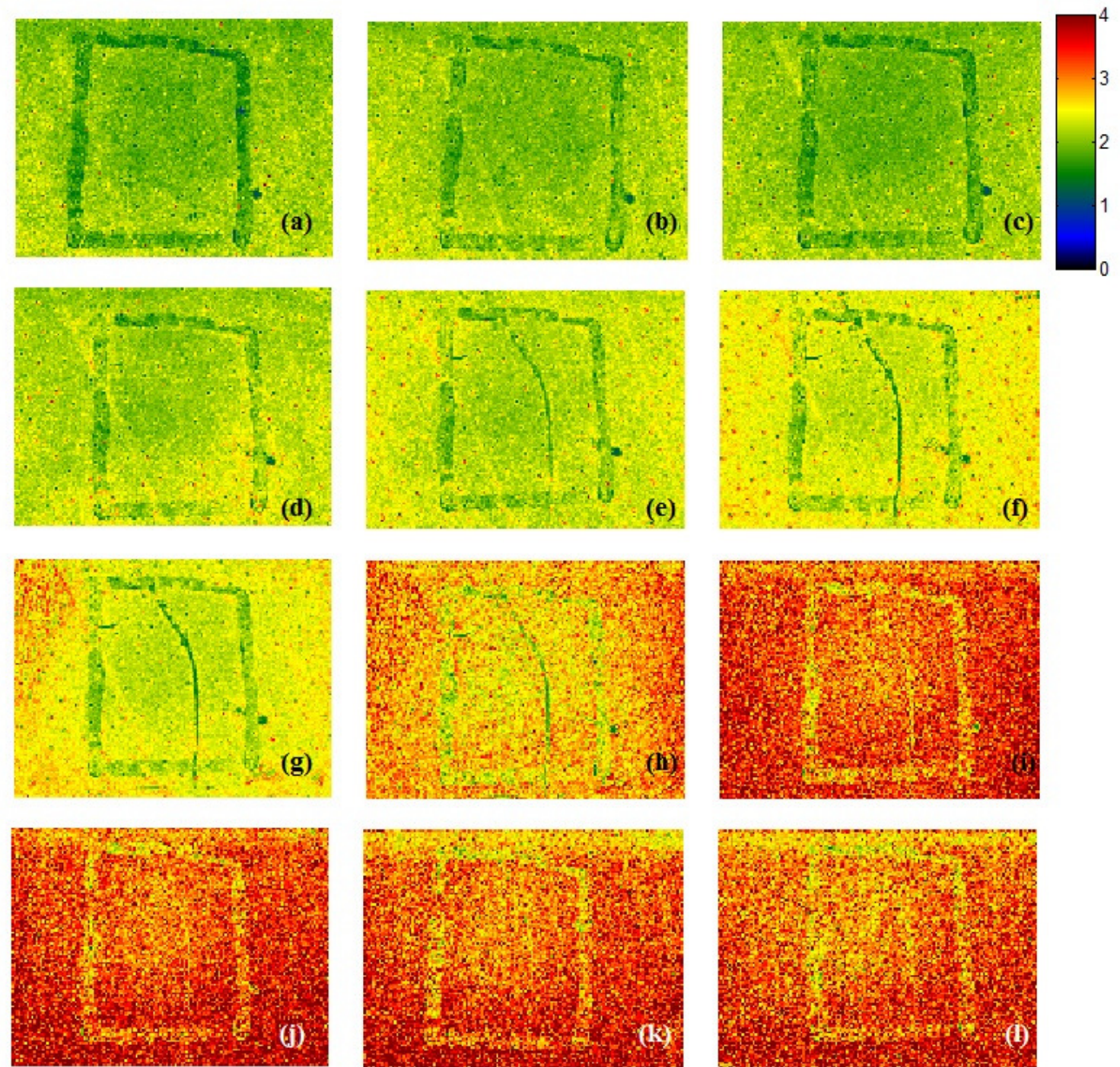

Figura 5.11 - Imagens espectrais da razão RF/FRF calculada a partir de uma das amostras de um grupo experimental com dez folhas sadias. O número de figuras é relativo ao número de dias em que a fluorescência foi monitorada, de forma que a figura (a) se refere às imagens espectrais do dia 1 e a figura (l) se refere às imagens espectrais do dia 12.

Complementando os resultados, apresentamos na Figura 5.12 os gráficos da distribuição da RF/FRF e da sua derivada (Figura 5.12a) e da R1 e sua derivada (Figura 5.12b) em função do tempo de colheita das amostras. A partir desses gráficos vemos que o comportamento da RF/FRF (Figura 5.12a) apresenta um crescimento a partir do segundo dia, atingindo um pico no nono dia e apresenta um padrão estável a partir de então. A derivada da RF/FRF também é mostrada nesta figura e apresenta um comportamento de crescimento até o sétimo dia, evanesce significativamente até o décimo dia e apresenta uma estabilidade a partir de então. 
O comportamento da razão R1 (Figura 5.12b) apresenta um período de estabilidade até o sexto dia e a partir desse um crescimento, até voltar a estabilidade no $11^{\circ}$ dia. Já o comportamento da derivada de R1 apresenta um comportamento de menor variação até o quinto dia quando cresce significativamente atingindo um pico no oitavo dia e evanesce significativamente até o $12^{\circ}$ dia.
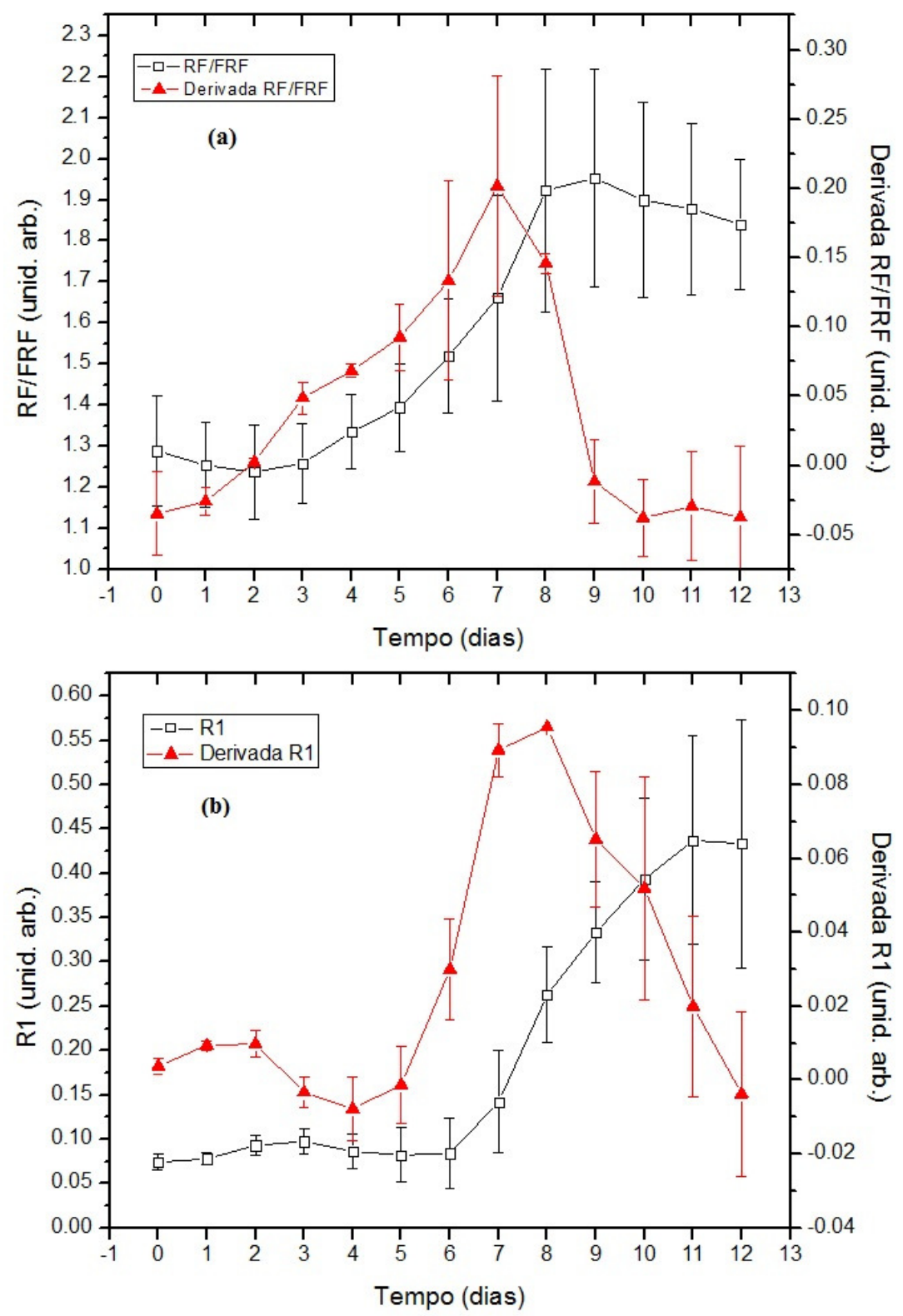

Figura 5.12 - Gráficos da evolução da RF/FRF e da sua derivada (a) e de R1 e sua derivada (b) em função do tempo entre a colheita da folha e a medição da fluorescência. 
O comportamento da derivada de R1 é muito parecido com o comportamento da emissão de etileno por parte das folhas maduras em ambiente aéreo (Figura 5.10b). Ambos apresentam um comportamento estável nos primeiros dias de colheita e começam a crescer a partir do quinto dia. Nos dados da espectroscopia de massa o pico de emissão de etileno é atingido no nono dia enquanto que a curva da derivada de R1 apresenta o pico no oitavo dia. É possível que esse deslocamento seja causado pela própria característica das amostras utilizadas ou do ambiente onde se encontram. 


\section{CONCLUSÕES}

Durante todo o programa de doutorado um longo caminho foi percorrido; desde os primeiros experimentos foi necessário adaptação à multidisciplinaridade da proposta oferecida e persistência para o desenvolvimento do trabalho. Deste, destacamos algumas lições aprendidas.

Inicialmente, em relação à LIF podemos concluir que a folha não é a melhor unidade de diagnóstico, pois suas características particulares, como idade, concentração da clorofila, senescência, etc., influenciam o resultado final. Essa observação foi feita nos experimentos da LIF no laboratório que mostraram a viabilidade em discriminar folhas sadias de folhas contaminadas por cancro cítrico (Figura 4.3a), porém também mostraram a sobreposição dos valores das razões ao tentar discriminar o cancro da CVC (Figura 4.3b). Daí a opção por não utilizar o resultado individual das folhas para discriminar o cancro.

Concluímos também que folhas destacadas sofrem estresse que depende do tempo de destacamento e que pode afetar o resultado final da LIF e das figuras de mérito (FM), como conseqüência. Vale lembrar que não há relatos na literatura de que tal efeito deve ser evitado. Essa conclusão foi permitida depois de realizarmos um experimento que comprovou a dependência da emissão da fluorescência das folhas com o tempo de destacamento da planta-mãe (Figura 4.4). Concluímos que esse comportamento representa o próprio processo de senescência da folha acelerado pelo destacamento.

Também observamos que as condições ambientais podem levar a variações na emissão da fluorescência de folhas da mesma planta. A literatura reporta que as condições do clima, da temperatura, do fornecimento de água e do solo na região das fazendas onde as plantas foram estudadas influenciavam a emissão da fluorescência das folhas, pois cada uma delas induz, por si só, um diferente tipo de estresse na planta; por isso deve haver cuidado na interpretação do resultado obtido.

Contudo, aprendemos que procedimentos simples podem evitar tais problemas ou pelo menos minimizar a dependência da emissão da fluorescência das amostras. Dentre os quais destacamos que devemos tomar a árvore como a unidade do diagnóstico para diminuir a dispersão dos valores das razões. Essa conclusão foi possível devido aos resultados dos experimentos da LIF no campo. Neste, as FM eram calculadas por folha, mas a informação de contaminação da árvore era baseada na média das FM das folhas. Como conseqüência, o desvio 
padrão dos dados diminuiu, de forma que cada planta contaminada por cancro apresentou desvios variando entre $5 \%$ e $35 \%$ do valor médio da FM.

Outro fato é que devemos considerar a informação das folhas sadias para minimizar a dependência das FM com as condições do ambiente da fazenda. Foi possível observar que o desvio padrão das FM normalizadas era menor que das FM sem normalização. Além disso, os valores das FM normalizadas são uniformes independentemente das variedades cítricas; isso permitiu que a técnica fosse aplicada sem restrições com as variedades exploradas.

Por fim passamos a realizar as medidas da fluorescência das amostras imediatamente após a colheita da folha na intenção de evitar os efeitos do estresse causados pela aceleração do processo de senescência. Para isso tínhamos de realizar os experimentos no campo.

Todas as conclusões acima são importantes, mas temos que destacar que a nossa principal conclusão em aplicar a LIF para o diagnóstico na citricultura é que se a doença ou o estresse gera sintomas característicos e localizados na folha, então a espectroscopia da fluorescência a fibra não é apropriada, pois sempre haverá o problema de posicionamento da fibra sobre o sintoma. Talvez a LIF a fibra seja uma boa técnica para detectar doenças ou estresse que atinjam a planta ou a folha como um todo, como no caso do déficit hídrico ou do estresse por deficiência de minerais no solo.

Em relação aos experimentos de espectroscopia das imagens da fluorescência utilizando o espectrógrafo, podemos concluir que o SIE é um sistema muito potente e versátil, pois permite a observação completa dos espectros capturados em uma pequena região espacial da região de interesse; dessa forma ele fornece tanto resolução espectral quanto espacial. Infelizmente o SIE não é prático para ser levado ao campo, pois necessita ambiente com controle da iluminação para que as imagens capturadas permitam uma razão sinal-ruído relevante. Além disso, o SIE é lento na captura das imagens devido à sua própria instrumentação. Utilizando esse sistema, no máximo 15 folhas seriam estudadas por dia.

As imagens espectrais obtidas também não foram satisfatórias. Apesar das tentativas, não conseguimos remover eficientemente a influência da área da fenda do espectrógrafo sobre as imagens espectrais. Assim, a conclusão sobre o SIE é que serve como um equipamento inicial para definir as regiões espectrais de interesse. Um exemplo foi a observação da emissão da fluorescência em $615 \mathrm{~nm}$ que talvez tenha o potencial de ser utilizada no diagnostico do cancro.

Em relação aos experimentos de espectroscopia das imagens da fluorescência utilizando o sistema com uma roda de filtros ópticos, podemos concluir que o SIF é versátil e portátil, 
de forma que sua aplicação no campo se dá sem maiores problemas. Sua instrumentação permite aquisições das imagens espectrais em tempos menores que o sistema com o espectrógrafo. Com ele, em uma única viagem foi possível montar um banco de imagens espectrais de 95 folhas de 19 plantas. O SIF também permite a melhor resolução espacial da região de interesse com a resolução espectral que desejávamos. O arranjo do SIF ainda permitia que outras partes da planta fossem estudadas, inclusive os frutos.

Vale destacar que a quantidade de dados a serem analisados cresceu significativamente com o uso das imagens espectrais, de forma que as imagens espectrais das amostras foram apresentadas do ponto de vista qualitativo. Acreditamos que um processamento das imagens que leve em consideração a resolução espacial e a espectral deve ser aplicado para que o trabalho tenha segmento. Mesmo assim fomos capazes de realizar um experimento onde obtivemos uma analise quantitativa da fluorescência emitida por folhas destacadas da planta-mãe e correlacionamos o seu comportamento com a emissão de etileno por amostras nas mesmas condições experimentais.

Durante este trabalho dois sistemas robustos (o espectrômetro portátil e o sistema de imagens por filtros ópticos) foram aplicados em experimentos no campo. Para o futuro acreditamos que tais sistemas poderão ser aplicados para detectar outros estresses em outras culturas ou produtos agrícolas. 


\section{REFERÊNCIAS}

1. ASSOCIAÇÃO BRASILEIRA DOS EXPORTADORES DE CÍTRICOS (ABECITRUS). Disponível em: <http://www.abecitrus.com.br>. Acesso em: 03 de abril de 2009.

2. ALEIXOS, N.; BLASCO, J.; NAVARRÓN, F.; MOLTÓ, E. Multispectral inspection of citrus in real-time using machine vision and digital signal processors. Computers and Electronics in Agriculture, v. 33, n. 2, p. 121-137, 2002.

3. APOSTOL, S.; VIAU, A. A.; TREMBLAY, N.; BRIANTAIS, J-M.; PRASHER, S.; PARENT, L-E.; MOYA, I. Laser-induced fluorescence signatures as a tool for remote monitoring of water and nitrogen stresses in plants. Canadian Journal of Remote Sensing, v. 29, n. 1, p. 57-65, 2003.

4. ATKINS, P.; DE PAULA, J. Físico-química. 7. Ed. Rio de Janeiro: LTC-Livros Técnicos e Científicos, 2004. v. 2.

5. BAKER, N. R. Chlorophyll fluorescence: a probe of photosynthesis in vivo. Annual Review of Plant Biology, v. 59, n.1, p.89-113, 2008.

6. BALASUNDARAM, D.; BURKS, T. F.; BULANONA, D. M.; SCHUBERT, T.; LEE, W. S. Spectral reflectance characteristics of citrus canker and other peel conditions of grapefruit. Postharvest Biology and Technology, v. 51, n. 2, p. 220-226, 2009.

7. BARBOSA, J. C.; GIMENES-FERNANDES, N.; MASSARI, C. A.; AYRES, A. J. Incidência e distribuição de cancro cítrico em pomares comerciais do estado de São Paulo e sul do Triângulo Mineiro. Summa Phytopathologica, v. 27, n. 1, p. 30-35, 2001.

8. BELASQUE JR., J.; GASPAROTO, M. C. G.; MARCASSA, L. G. Detection of mechanical and disease stresses in citrus plants by fluorescence spectroscopy. Applied Optics, v. 47, n. 11, p. 1922-1926, 2008.

9. BLASCO, J.; ALEIXOS, N.; MOLTÓ, E. Computer vision detection of peel defects in citrus by means of a region oriented segmentation algorithm. Journal of Food Engineering, v. 81, n.3, p. 535-543, 2007.

10. BLASCO, J.; ALEIXOS, N.; GOMEZ, J.; MOLTÓ, E. Citrus sorting by identification of the most common defects using multispectral computer vision. Journal of Food Engineering, v. 83, n. 3, p. 384-393, 2007. 
11. BLASCO, J.; ALEIXOS, N.; MOLTÓ, E. Machine vision system for automatic quality grading of fruit. Biosystems Engineering, v. 85, n. 4, p. 415-423, 2003.

12. BOLHAR-NORDENKAMPF, H. R.; LONG, S. P.; BAKER, N. R.; OQUIST, G.; SCHREIBER, U.; LECHNER, E. G. Chlorophyll Fluorescence as a Probe of the Photosynthetic Competence of Leaves in the Field: a review of current instrumentation. Functional Ecology, v. 3, n. 4, p. 497-514, 1989.

13. BORN, M.; WOLF, E. Principles of Optics. 7. ed. New York: Cambridge University Press, 1999.

14. BOVÉ, J. M. Huanglongbing: a destructive, newly-emerging, century-old disease of citrus. Journal of Plant Pathology, v. 88, n. 1, p. 7-37, 2006.

15. BRASIL. Ministério da Agricultura, Pecuária e Abastecimento. Produtos do agronegócio: exportações, importações mundiais e inserção brasileira. Brasília, DF. Disponível em: $<$ http://www.agricultura.gov.br/images/MAPA//arquivos_portal/ACS/PRODUTOS_DO_ AGRONEGOCIO.pdf>. Acesso em: 10 de agosto de 2009.

16. BUSCHMANN, C.; LANGSDORF, G.; LICHTENTHALER, H. K. Imaging of the blue, green and red fluorescence emission of plants: an overview. Photosynthetica, v. 38, n. 4, p. 483-491, 2000.

17. CEROVIC, Z. G.; SAMSON, G.; MORALES, F.; TREMBLAY, N.; MOYA, I. Ultraviolet-induced fluorescence for plant monitoring: present state and prospects. Agronomie, v. 19, p. 543-578, 1999.

18. CHAPELLE, E. W.; MCMURTREY III, J. E.; WOOD JR., F. M.; NEWCOMB, W. W. Laser-induced fluorescence of green plants. 2: LIF caused by nutrient deficiencies in corn. Applied Optics, n. 23, n.1, p. 139-142, 1984.

19. CHEN, Y; CHAO, K.; KIM, M. S. Machine vision technology for agricultural applications. Computers and Electronics in Agriculture, v. 36, n.2-3, p. 173-191, 2002.

20. CLOUTIS, E. A. Hyperspectral geological remote sensing: evaluation of analytical techniques. International Journal of Remote Sensing, v. 17, n. 12, p. 2215-2242, 1996. 
21. COZZOLINO, D.; FASSIO, A.; GIMENEZ, A. The use of near-infrared reflectance spectroscopy (NIRS) to predict the composition of whole maize plants. Journal of the Science of Food and Agriculture, v. 81, n. 1, p. 142-146, 2000.

22. CUBERO, J.; GRAHAM, J. H.; GOTTWALD, T. R. Quantitative PCR method for diagnosis of citrus bacterial canker. Applied and Environmental Microbiology, v. 67, n. 6, p. 2849-2852, 2001.

23. CVC - Clorose Variegada dos Citrus. Disponível em:

$<$ http://www.fundecitrus.com.br/ImageBank/PageFlip/pageflip.aspx?idPage=137>. Acesso em 10 de agosto de 2009.

24. DA GRAÇA, J. V. Citrus greening disease. Annual Review of Phytopathology, v. 29, p. 109-136, 1991.

25. DAS, A. K. Citrus canker: a review. Journal Applied of Horticulture. v. 5, n. 1, p. $52-$ 60, 2003.

26. ELVIDGE, C. D. Visible and near infrared reflectance characteristics of dry plant materials. International Journal of Remote Sensing, v.11, n.10, p. 1775-1795, 1990.

27. FLETCHER-HOLMES, D. W.; HARVEY, A. R. Real-time imaging with a hyperspectral fovea. Journal of Optics A: pure applied Optics, v. 7, n.6, p. S298-S302, 2005.

28. FLEXAS, J.; BRIANTAIS, J-M.; CEROVIC, Z.; MEDRANO, H.; MOYA, I. Steady-state and maximum chlorophyll fluorescence response to water stress in grapevine leaves: A new remote sensing system. Remote Sensing of Environment, v. 73, n.3, p. 283-297, 2000.

29. GARCIA, A. Status and prospects of orange juice in Brazil. Disponível em: $<w w w . a b e c i t r u s . c o m . b r / e s t u d o s \_b r . h t m l>$. Acesso em 3 de abril de 2009.

30. GARCÍA-REYES, J. F.; LLORENT-MARTÍNEZ, E. J.; ORTEGA-BARRALES, P.; MOLINA-DÍAZ A. Determination of thiabendazole residues in citrus fruits using a multicommuted fluorescence-based optosensor. Analytica Chimica Acta, v. 557, n.1-2, p. 95100, 2006. 
31. GASPAROTO, M. C. G. Relações entre Espectroscopia de Fluorescência, Fotossíntese e Severidade do Cancro Cítrico (Xanthomonas axonopodis pv. citri). 2006. 64 f. Dissertação (Mestrado em Agronomia) - Escola Superior de Agricultura "Luiz de Queiroz", Universidade de São Paulo, Piracicaba, 2006.

32. GOWEN, A. A.; O'DONNELLA, C. P.; CULLENB, P. J.; DOWNEYC, G.; FRIAS, J. M. Hyperspectral imaging - an emerging process analytical tool for food quality and safety control. Trends in Food Science \& Technology, v. 18, n. 12, p. 590-598, 2007.

33. HALLIDAY, D.; RESNICK, R.; KRANE, K. S., Física 4, 4. ed. Rio de Janeiro: LTCLivros Técnicos e Científicos Editora S.A., 1996.

34. JACKSON, R. D. Remote sensing of biotic and abiotic plant stress. Annual Review of Phytopathology, v. 24, p. 265-287, 1986.

35. JIANG, X.; TANG, L.; WANG, C. Y.; WANG, C. Spectral characteristics and feature selection of hyperspectral remote sensing data. International Journal of Remote Sensing, v. 25, n.1, p. 51-59, 2004.

36. JUSOFF, K.; PATHAN, M. Mapping of individual oil palm trees using airborne hyperspectral sensing: an overview. Applied Physics Research, v. 1, n.1, p. 15-30, 2009.

37. KATZ, E.; RIOV, J.; WEISS, D.; GOLDSCHMIDT, E. E. The climacteric-like behaviour of young, mature and wounded citrus leaves. Journal of Experimental Botany, v. 56, n. 415, p. 1359-1367, 2005.

38. KIM, M. S.; LEFCOURT, A. M.; CHEN, Y. R.; KIM, I.; CHAN, D. E.; CHAO, K. Multispectral detection of fecal contamination on apples based on hyperspectral imagery: part I. application of visible and near-infrared reflectance imaging. Transactions of the ASAE, v. 45, n. 6, p. 2027-2037, 2002.

39. KIM, M. S.; LEFCOURT, A. M.; CHEN, Y. R.; KIM, I.; CHAN, D. E.; CHAO, K. Multispectral detection of fecal contamination on apples based on hyperspectral imagery: part II. application of hyperspectral fluorescence imaging. Transactions of the ASAE, v. 45, n. 6, p. 2039-2047, 2002.

40. KIM, M. S.; CHEN, Y. R.; MEHL, P. M. Hyperspectral reflectance and fluorescence imaging system for food quality and safety. Transactions of the ASAE, v. 44, n.3, p. 721729, 2001. 
41. KLEYNEN, O.; LEEMANS, V.; DESTAIN M.-F. Development of a multi-spectral vision system for the detection of defects on apples. Journal of Food Engineering, v. 69, n.1, p. 41-49, 2005.

42. LAWLOR, D. W. Photosynthesis. 3. ed. New York: BIOS Scientific Publishers Ltd., 2001.

43. LENK, S.; CHAERLE, L.; PFUNDEL, E. E.; LANGSDORF, G.; HAGENBEEK, D.; LICHTENTHALER, H. K.; VAN DER STRAETEN, D.; BUSCHMANN, C. Multispectral fluorescence and reflectance imaging at the leaf level and its possible applications, Journal Experimental Botany: imaging stress responses in plants Special Issue. doi:10.1093/jxb/erl207, 2007.

44. LICHTENTHALER, H. K.; BABANI, F. Detection of photosynthetic activity and water stress by imaging the red chlorophyll fluorescence. Plant Physiology et Biochemistry, v. 38, n.11, p. 889-895, 2000.

45. LICHTENTHALER, H.; MIEHÉ, J. Fluorescence imaging as a diagnostic tool for plant stress. Trends Plant Science. v. 2, n. 8, p. 316-320, 1997.

46. LINS, E. C. C. C. Técnicas Ópticas para a Análise da Manifestação do Estresse Hídrico em Laranjeiras. 2005. 102 f. Dissertação (Mestrado em Engenharia Eletrônica) Departamento de Eletrônica e Sistemas, Universidade Federal de Pernambuco, Recife, 2005.

47. LINS, E. C.; BELASQUE JR., J.; MARCASSA, L. G. Detection of citrus canker in citrus plants using LASER induced fluorescence spectroscopy. Precision Agriculture, v. 10, p. 319-330, 2009. DOI 10.1007/s11119-009-9124-2.

48. MANUAL de Cancro Cítrico. Disponível em:

$<$ http://www.fundecitrus.com.br/ImageBank/PageFlip/pageflip.aspx?idPage=66>. Acesso em 10 de agosto de 2009.

49. MANUAL de Greening. Disponível em: $<$ http://www.fundecitrus.com.br/ImageBank/PageFlip/pageflip.aspx?idPage=68>. Acesso em 10 de agosto de 2009.

50. MARCASSA, L. G.; GASPAROTO, M. C. G.; BELASQUE JR., J.; LINS, E. C.; DIAS NUNES, F.; BAGNATO, V. S Fluorescence spectroscopy applied to orange trees. Laser Physics, v. 16, n. 5, p. 884-888, 2006. 
51. MASSARI, C. A.; BELASQUE JR., J. Campanha de erradicação do cancro cítrico no estado de São Paulo - situação atual e contaminação em viveiros. Laranja, v. 27, n. 1, p. 41-55, 2006.

52. MAXWELL, K.; JOHNSON, G. N. Chlorophyll fluorescence - a practical guide. Journal of Experimental Botany, v. 51, n. 345, p. 659-668, 2000.

53. NICOLAI, B. M.; BEULLENS, K.; BOBELYN, E.; PEIRS, A.; SAEYS, W.; THERON, K. I.; LAMMERTYN, J. Nondestructive measurement of fruit and vegetable quality by means of NIR spectroscopy: A review. Postharvest Biology and Technology, v.46, n.2, p. 99-118, 2007.

54. NILSSON, H. Remote sensing and image analysis in plant pathology, Annual Review of Phytopathology, v. 5, p. 489-527, 1995.

55. REZENDE, S. M. A Física de materiais e dispositivos eletrônicos. Recife: Ed. Universitária UFPE, 1996.

56. PEÑUELAS, J.; FILELLA, I. Visible and near-infrared reflectance techniques for diagnosing plant physiological status. Trends in Plant Science, v.3, n. 4, p. 151-156, 1998.

57. PYDIPATI, R.; BURKS, T. F.; LEE, W. S. Identification of citrus disease using color texture features and discriminant analysis. Computers and Electronics in Agriculture, v. 52, n. 1, p. 49-59, 2006.

58. QIN, J.; BURKS, T. F.; RITENOUR, M. A.; GORDON BONN, W. Detection of citrus canker using hyperspectral reflectance imaging with spectral information divergence. Journal of Food Engineering, v. 93, n.2, p. 183-191, 2009.

59. QIN, J.; BURKS, T. F.; KIM, M. S.; CHAO, K.; RITENOUR, M. A. Citrus canker detection using hyperspectral reflectance imaging and PCA-based image classification method. Sensing \& Instrumentation for Food Quality and Safety, v. 2, n.3, p. 168-177, 2008. Doi 10.1007/s11694-008-9043-3

60. SÃO PAULO (Estado). Resolução CEE-CANECC/SP N.\&\#61616; 01/2000, de 20 de março de 2000. Diário Oficial [do] Estado de São Paulo. São Paulo, SP, 21 de março de 2000. Disponível em:

$<$ http://www.cda.sp.gov.br/www/legislacoes/popup.php?action=view\&idleg=694>. Acesso em: 10 de agosto de 2009. 
61. SCOTFORD, I. M.; MILLER, P. C. H. Applications of spectral reflectance techniques in northern european cereal production: a review. Biosystems Engineering, v. 90, n. 3, p. 235-250, 2005.

62. SIMÓ, C.; MARTÍN-ALVAREZ, P. J.; BARBAS, C.; CIFUENTES, A. Application of stepwise discriminant analysis to classify commercial orange juices using chiral micellar electrokinetic chromatography-LASER induced fluorescence data of amino acids. Electrophoresis, v. 25, n. 16, p. 2885-2891, 2004.

63. SIMPSON, A. J. G. et al. The genome sequence of the plant pathogen Xylella fastidiosa. Nature, v. 406, n. 6792, p. 151-157, 2000.

64. TAN, M. K.; TIMMER, L. W.; BROADBENT, P.; PRIEST, M.; CAIN, P. Differentiation by molecular analysis of Elsinoe spp. causing scab diseases of citrus and its epidemiological implications. Phytopathology v. 86, n. 10, p. 1039-1044, 1996.

65. THORLABS. Disponível em: <www.thorlabs.com>. Acesso em 19 de janeiro de 2009.

66. VERNIÈRE, C. J.; GOTTWALD, T. R.; PRUVOST, O. Disease development and symptom expression of Xanthomonas axonopodis pv. citri in various citrus plant tissue. Phytopathology, v. 93, n. 7, p. 832-843, 2003.

67. THROOP, J. A.; ANESHANSLEY, D. J.; ANGER, W. C.; PETERSON, D. L. Quality evaluation of apples based on surface defects: development of an automated inspection system. Postharvest Biology and Technology, v. 36, n.3, p. 281-290, 2005.

68. VO-DIHN, T. Biomedical Photonics Handbook. Boca Raton: CRC Press, 2003.

69. WARDLEY, T. M.; BHALLA, P. L.; DALlinG, M. E. Changes in the number and composition of chloroplasts during senescence of mesophyll cells of attached and detached primary leaves of wheat (triticum aestivum L.). Plant Physiology, v. 75, n. 2, p. 421-424, 1984.

70. ZHANG, M.; LIU, X.; O'NELL, M. Spectral discrimination of phytophthora infests infection on tomatos based on principal component and cluster analysis. International Journal of Remote Sensing v. 23, n. 6, p. 1095-1107, 2002. 
APÊNDICE A - TABELA DE DADOS DA ESPECTROSCOPIA DA FLUORESCÊNCIA REALIZADA NO CAMPO.

\begin{tabular}{|c|c|c|c|c|c|c|c|c|}
\hline $\begin{array}{c}\text { Árvore } \\
\text { no- }\end{array}$ & $\begin{array}{l}\text { Classificação } \\
\text { do pragueiro }\end{array}$ & $\begin{array}{l}\text { Média } \\
\text { FM1n }\end{array}$ & $\begin{array}{l}\text { Média } \\
\text { FM2n }\end{array}$ & $\begin{array}{l}\text { Média } \\
\text { FM3n }\end{array}$ & $\begin{array}{l}\text { Média } \\
\text { FM4n }\end{array}$ & $\begin{array}{l}\text { Média } \\
\mathrm{C}(0) \mathrm{n}\end{array}$ & $\begin{array}{c}\text { Média } \\
\text { RF/FRFn }\end{array}$ & Laboratório \\
\hline 1 & cancro & 1.45 & 131.306 & 0.192 & 23.025 & 0.082 & 1.709 & Positivo \\
\hline 2 & cancro & 1.44 & & 0.3 & & 0.141 & 1.992 & Positivo \\
\hline 3 & cancro & 1.55 & & 0.408 & & 0.307 & 2.36 & Positivo \\
\hline 5 & cancro & 1.15 & & 0.76 & & 0.609 & 1.311 & Positivo \\
\hline 7 & cancro & 1.61 & 9.824 & 0.473 & 3.564 & 0.356 & 2.143 & Positivo \\
\hline 9 & cancro & 1.34 & 8.566 & 0.674 & 4.649 & 0.44 & 1.545 & Positivo \\
\hline 10 & cancro & 1.52 & 3.188 & 0.74 & 1.921 & 0.576 & 1.916 & Positivo \\
\hline 11 & cancro & 1.15 & 1.599 & 0.719 & 1.169 & 0.505 & 1.272 & Positivo \\
\hline 12 & cancro & 1.39 & 3.629 & 0.733 & 2.067 & 0.515 & 1.727 & Positivo \\
\hline 14 & cancro & 1.72 & 5.23 & 0.451 & 2.616 & 0.21 & 2.44 & Positivo \\
\hline 15 & cancro & 1.55 & 9.19 & 0.532 & 4.911 & 0.294 & 1.967 & Positivo \\
\hline 16 & cancro & 1.79 & 17.185 & 0.437 & 5.125 & 0.267 & 2.484 & Positivo \\
\hline 17 & cancro & 1.22 & 0.804 & 0.681 & 0.443 & 0.448 & 1.438 & Positivo \\
\hline 18 & cancro & 1.49 & 6.266 & 1.659 & 6.587 & 2.674 & 2.048 & Positivo \\
\hline 19 & cancro & 1.50 & 3.657 & 1.21 & 5.459 & 1.172 & 1.736 & Positivo \\
\hline 20 & cancro & 1.41 & 1.021 & 0.712 & 0.569 & 0.546 & 1.67 & Positivo \\
\hline 21 & cancro & 2.19 & & 0.492 & & 0.338 & 3.458 & Positivo \\
\hline 22 & cancro & 1.49 & & 0.197 & & 0.029 & 1.883 & Positivo \\
\hline 23 & cancro & 1.83 & & 0.3 & & 0.161 & 2.884 & Positivo \\
\hline 24 & cancro & 1.67 & 20.719 & 0.206 & 2.423 & 0.072 & 2.12 & Positivo \\
\hline 25 & cancro & 1.57 & 8.506 & 0.388 & 2.617 & 0.226 & 1.936 & Positivo \\
\hline 26 & cancro & 1.53 & 9.414 & 0.425 & 3.007 & 0.226 & 1.85 & Positivo \\
\hline 27 & cancro & 1.40 & 3.571 & 0.701 & 2.477 & 0.504 & 1.633 & Positivo \\
\hline 29 & cancro & 1.54 & 3.702 & 0.675 & 2.242 & 0.476 & 1.939 & Positivo \\
\hline 31 & cancro & 1.65 & 4.922 & 0.778 & 3.114 & 0.639 & 2.085 & Negativo \\
\hline 33 & cancro & 1.39 & 4.118 & 0.379 & 1.191 & 0.18 & 1.648 & Positivo \\
\hline 34 & cancro & 1.79 & 5.033 & 0.448 & 1.595 & 0.19 & 2.555 & Positivo \\
\hline 35 & cancro & 1.72 & 6.874 & 0.485 & 2.034 & 0.255 & 2.445 & Positivo \\
\hline 36 & cancro & 1.85 & 4.07 & 0.619 & 2.481 & 0.446 & 2.597 & Positivo \\
\hline 37 & cancro & 1.72 & 7.565 & 1.174 & 4.77 & 1.615 & 2.484 & Positivo \\
\hline 38 & cancro & 1.23 & 1.552 & 1.093 & 1.564 & 1.539 & 1.419 & Positivo \\
\hline 39 & cancro & 1.34 & 1.155 & 1.059 & 1.14 & 0.716 & 1.632 & Positivo \\
\hline 41 & cancro & 1.67 & 12.244 & 0.388 & 2.432 & 0.19 & 2.541 & Positivo \\
\hline 42 & cancro & 1.16 & 0.98 & 2.394 & 1.961 & 6.423 & 1.287 & Positivo \\
\hline 44 & cancro & 1.14 & 0.822 & 1.804 & 1.638 & 2.448 & 1.333 & Positivo \\
\hline 45 & cancro & 1.55 & 3.94 & 1.149 & 4.974 & 1.643 & 2.028 & Positivo \\
\hline 46 & cancro & 1.22 & 49.458 & 0.735 & 2.563 & 0.255 & 1.549 & Positivo \\
\hline 47 & cancro & 1.80 & 30.577 & 0.514 & 13.707 & 0.234 & 2.866 & Positivo \\
\hline 48 & cancro & 1.30 & 4.739 & 0.784 & 2.632 & 0.23 & 1.619 & Positivo \\
\hline 49 & cancro & 1.24 & 5.89 & 1.186 & 5.34 & 2.43 & 1.478 & Positivo \\
\hline
\end{tabular}


Continuação

\begin{tabular}{|c|c|c|c|c|c|c|c|c|}
\hline 50 & cancro & 1.76 & 26.163 & 0.997 & 6.23 & 1.445 & 2.782 & Positivo \\
\hline 51 & cancro & 1.77 & 106.145 & 0.251 & 20.334 & 0.085 & 2.43 & Positivo \\
\hline 52 & cancro & 1.85 & 112.141 & 0.442 & 34.92 & 0.29 & 2.719 & Positivo \\
\hline 54 & cancro & 1.66 & 172.419 & 0.39 & 18.413 & 0.158 & 2.529 & Positivo \\
\hline 56 & cancro & 1.76 & 385.156 & 0.326 & 3.992 & 0.186 & 2.246 & Positivo \\
\hline 57 & cancro & 1.64 & 108.885 & 0.524 & 53.698 & 0.358 & 2.198 & Positivo \\
\hline 58 & cancro & 1.71 & 46.248 & 0.215 & 18.874 & 0.051 & 2.441 & Positivo \\
\hline 59 & cancro & 1.76 & 117.983 & 0.96 & 38.795 & 2.475 & 2.38 & Positivo \\
\hline 60 & cancro & 1.77 & 4.141 & 0.546 & 1.638 & 0.31 & 2.746 & Positivo \\
\hline 62 & cancro & 1.21 & 2.885 & 0.78 & 2.04 & 0.744 & 1.444 & Positivo \\
\hline 63 & cancro & 1.69 & 9.072 & 0.815 & 6.2 & 0.77 & 2.342 & Positivo \\
\hline 64 & cancro & 1.52 & 3.954 & 0.783 & 2.436 & 0.524 & 2.054 & Positivo \\
\hline 65 & cancro & 1.85 & 7.447 & 0.715 & 3.825 & 0.511 & 2.593 & Positivo \\
\hline 66 & cancro & 1.78 & 9.348 & 0.47 & 1.784 & 0.227 & 2.519 & Positivo \\
\hline 67 & cancro & 1.91 & 4.89 & 0.519 & 2.04 & 0.268 & 2.765 & Positivo \\
\hline 68 & cancro & 1.76 & 12.248 & 0.482 & 2.805 & 0.196 & 2.473 & Positivo \\
\hline 69 & cancro & 1.51 & 7.197 & 0.94 & 4.76 & 0.829 & 2.409 & Positivo \\
\hline 70 & cancro & 1.72 & 5.504 & 0.734 & 3.523 & 0.653 & 2.739 & Positivo \\
\hline 72 & cancro & 1.81 & 25.15 & 0.628 & 6.246 & 0.561 & 2.728 & Positivo \\
\hline 73 & cancro & 1.57 & 2.687 & 0.778 & 1.668 & 0.644 & 2.29 & Positivo \\
\hline 74 & cancro & 1.30 & 9.116 & 1.161 & 5.825 & 1.484 & 1.571 & Positivo \\
\hline 75 & cancro & 1.56 & 3.739 & 0.618 & 2.069 & 0.529 & 1.996 & Positivo \\
\hline 76 & cancro & 1.27 & 3.921 & 0.894 & 2.454 & 1.07 & 1.508 & Positivo \\
\hline 77 & cancro & 1.60 & 47.079 & 0.786 & 4.639 & 0.761 & 2.23 & Positivo \\
\hline 78 & cancro & 1.32 & 9.574 & 0.521 & 4.834 & 0.38 & 1.544 & Positivo \\
\hline 80 & cancro & 1.30 & 3.403 & 1.177 & 3.549 & 1.606 & 1.483 & Positivo \\
\hline 82 & cancro & 1.51 & 34.739 & 0.693 & 16.078 & 1.439 & 2.083 & Positivo \\
\hline 83 & cancro & 1.44 & 222.492 & 0.941 & 8.533 & 1.104 & 2.412 & Positivo \\
\hline 84 & cancro & 1.65 & 0.088 & 1.137 & 6.23 & 1.099 & 1.744 & Positivo \\
\hline 85 & cancro & 1.52 & 8.916 & 0.743 & 6.25 & 0.565 & 1.83 & Positivo \\
\hline 87 & cancro & 1.41 & 5.959 & 0.748 & 4.75 & 0.303 & 1.706 & Positivo \\
\hline 88 & cancro & 1.76 & 110.611 & 0.669 & 109.109 & 0.527 & 2.339 & Positivo \\
\hline 89 & cancro & 1.88 & 353.475 & 0.65 & 200.978 & 0.441 & 2.538 & Positivo \\
\hline 90 & cancro & 1.25 & 11.712 & 2.201 & 9.395 & 0.863 & 1.502 & Positivo \\
\hline 91 & cancro & 1.62 & 655.083 & 0.567 & & 0.225 & 2.464 & Positivo \\
\hline 92 & cancro & 1.46 & 118.415 & 2.327 & & 3.261 & 1.948 & Positivo \\
\hline 93 & cancro & 1.59 & 29.996 & 0.39 & 1.671 & 0.155 & 2.096 & Positivo \\
\hline 94 & cancro & 1.58 & 53.681 & 0.545 & & 0.773 & 2.182 & Positivo \\
\hline 95 & cancro & 1.59 & 20.56 & 1.574 & 72.322 & 2.559 & 2.135 & Positivo \\
\hline 97 & cancro & 1.44 & 853.08 & & & & 2.229 & Positivo \\
\hline 98 & cancro & 1.59 & 89.858 & 1.032 & 444.958 & 0.776 & 2.071 & Positivo \\
\hline 99 & cancro & 1.51 & 122.144 & 0.735 & & 1.352 & 2.103 & Positivo \\
\hline 100 & cancro & 1.16 & 77.927 & 1.286 & 404.276 & 0.579 & 1.29 & Positivo \\
\hline 101 & cancro & 1.63 & 4.015 & 0.764 & 2.585 & 0.492 & 2.027 & Positivo \\
\hline 102 & cancro & 1.13 & 25.944 & 1.032 & 2.724 & 1.229 & 1.353 & Positivo \\
\hline 103 & cancro & 1.34 & 6.561 & 1.105 & 6.139 & 1.719 & 1.758 & Positivo \\
\hline 104 & cancro & 1.12 & 19.39 & 1.255 & 4.749 & 2.305 & 1.317 & Positivo \\
\hline 105 & cancro & 1.46 & 8.741 & 1.096 & 9.235 & 1.28 & 1.72 & Positivo \\
\hline 106 & cancro & 1.35 & 12.066 & 0.941 & 6.619 & 0.943 & 1.709 & Positivo \\
\hline 107 & cancro & 1.60 & 5.532 & 0.667 & 4.084 & 0.437 & 2.016 & Positivo \\
\hline
\end{tabular}

Continua 
Continuação

\begin{tabular}{|c|c|c|c|c|c|c|c|c|}
\hline 108 & cancro & 1.36 & 3.833 & 0.719 & 2.568 & 0.527 & 1.775 & Positivo \\
\hline 109 & cancro & 1.70 & 55.92 & 1.57 & 68.084 & 2.403 & 2.317 & Positivo \\
\hline 110 & cancro & 1.35 & 35.68 & 0.357 & 10.789 & 0.205 & 1.603 & Positivo \\
\hline 111 & cancro & 1.17 & 20.896 & 0.513 & 8.141 & 0.333 & 1.325 & Positivo \\
\hline 112 & cancro & 1.34 & 0.403 & 4.212 & 1.2 & 4.436 & 1.643 & Positivo \\
\hline 113 & cancro & 1.26 & 2.522 & 2.036 & 4.813 & 2.198 & 1.601 & Positivo \\
\hline 114 & cancro & 1.47 & 5.81 & 2.916 & 65.107 & 10.002 & 1.645 & Positivo \\
\hline 115 & cancro & 1.59 & 12.332 & 0.847 & 0.559 & 1.137 & 2.049 & Positivo \\
\hline 116 & cancro & 1.34 & 10.096 & 2.799 & & 7.948 & 1.658 & Positivo \\
\hline 118 & cancro & 1.26 & 7.983 & & & & 1.53 & Positivo \\
\hline 119 & cancro & 1.34 & & 0.371 & & 0.378 & 1.546 & Positivo \\
\hline 120 & cancro & 2.34 & 313.824 & 0.761 & 4.483 & 0.176 & 3.864 & Positivo \\
\hline 121 & cancro & 1.42 & 3.981 & & & & 2.002 & Positivo \\
\hline 122 & cancro & 1.52 & 98.216 & 0.536 & & 0.19 & 1.835 & Positivo \\
\hline 123 & cancro & 1.43 & 10.591 & 2.318 & 3.154 & 0.087 & 1.862 & Positivo \\
\hline 125 & cancro & 1.55 & 5.83 & 0.867 & 9.655 & & 1.816 & Positivo \\
\hline 126 & cancro & 1.43 & 6.368 & 1.253 & 25.682 & 1.583 & 1.723 & Positivo \\
\hline 127 & cancro & 1.44 & 5.957 & 0.275 & 2.782 & 0.275 & 2.154 & Positivo \\
\hline 4 & verrugose & 1.04 & & 0.808 & & 1.363 & 1.08 & Negativo \\
\hline 6 & verrugose & 1.05 & & 2.667 & & 5.123 & 1.097 & Negativo \\
\hline 8 & verrugose & 0.96 & & 1.405 & 0 & 2.23 & 0.953 & Negativo \\
\hline 13 & verrugose & 0.78 & 3.703704 & 1.471 & 0.347 & 1.933 & 0.693 & Negativo \\
\hline 28 & verrugose & 1.21 & 0.625782 & 1.037 & 1.444 & 1.216 & 1.264 & Negativo \\
\hline 30 & verrugose & 1.06 & | 6.802721 & 1.189 & 0.123 & 1.537 & 1.071 & Negativo \\
\hline 32 & verrugose & 1.19 & 2.762431 & 1.212 & 0.46 & 1.41 & 1.288 & Negativo \\
\hline 40 & verrugose & 0.93 & 1.626016 & 0.856 & 0.617 & 0.458 & 0.864 & Negativo \\
\hline 43 & verrugose & 1.26 & 0.415455 & 0.568 & 1.334 & 0.379 & 1.415 & Negativo \\
\hline 53 & verrugose & 1.07 & 0.023583 & 2.302 & 38.195 & 30.631 & 1.124 & Negativo \\
\hline 55 & verrugose & 1.38 & 0.013433 & 1.197 & 38.146 & 1.641 & 1.73 & Negativo \\
\hline 61 & verrugose & 1.33 & 0.385802 & 1.103 & 2.412 & 1.356 & 1.579 & Negativo \\
\hline 71 & verrugose & 1.14 & 0.573723 & 1.031 & 1.517 & 1.323 & 1.261 & Negativo \\
\hline 79 & verrugose & 1.04 & 0.013028 & 0.709 & 1.757 & 0.681 & 1.065 & Negativo \\
\hline 81 & verrugose & 1.28 & 0.063833 & 0.99 & 12.292 & 1.185 & 1.542 & Negativo \\
\hline 86 & verrugose & 1.17 & 0.048307 & 1.386 & 25.637 & 1.135 & 1.298 & Negativo \\
\hline 96 & verrugose & 1.57 & 0.00439 & 0.44 & 212.667 & 0.114 & 2.069 & Negativo \\
\hline 117 & verrugose & 1.82 & 0.00126 & 1.571 & & 1.604 & 2.708 & Negativo \\
\hline 124 & verrugose & 1.20 & 0.062325 & 1.498 & 41.832 & 0.134 & 1.557 & Negativo \\
\hline 132 & verrugose & 1.42 & 0.098658 & 0.495 & 1.303 & 0.365 & 1.856 & Negativo \\
\hline 183 & verrugose & 1.21 & 0.034613 & 0.344 & 10.363 & 0.231 & 1.406 & Negativo \\
\hline 184 & verrugose & 1.26 & 0.001651 & 0.48 & 8.431 & 0.336 & 1.157 & Negativo \\
\hline 185 & verrugose & 1.49 & 0.158078 & 0.563 & 2.571 & 0.197 & 1.812 & Negativo \\
\hline 186 & verrugose & 1.56 & 0.170911 & 0.617 & 3.398 & 0.175 & 1.971 & Negativo \\
\hline 187 & verrugose & 1.32 & 0.045204 & 0.441 & 10.01 & 0.239 & 1.889 & Negativo \\
\hline 188 & verrugose & 1.24 & 0.397298 & 0.501 & 1.257 & 0.421 & 1.368 & Negativo \\
\hline 189 & verrugose & 1.65 & 0.034341 & 0.705 & 19.614 & 0.481 & 2.346 & Negativo \\
\hline 190 & verrugose & 1.43 & 0.048026 & 0.703 & 15.205 & 0.449 & 1.783 & Negativo \\
\hline 191 & verrugose & 1.35 & 0.031894 & 0.369 & 11.688 & 0.244 & 1.562 & Negativo \\
\hline 192 & verrugose & 1.51 & 0.001567 & 0.247 & 13.028 & 0.1 & 1.606 & Negativo \\
\hline 193 & verrugose & 1.26 & 0.028399 & 1.004 & 34.989 & 1.125 & 1.696 & Negativo \\
\hline 194 & verrugose & 1.52 & 0.023495 & 1.453 & 71.064 & 1.695 & 2.148 & Negativo \\
\hline
\end{tabular}


Continuação

\begin{tabular}{|c|c|c|c|c|c|c|c|c|}
\hline 195 & verrugose & 1.04 & 0.902527 & 1.263 & 1.163 & 1.589 & 1.059 & Negativo \\
\hline 196 & verrugose & 1.15 & 0.019561 & 0.956 & 46.561 & 0.961 & 1.328 & Negativo \\
\hline 197 & verrugose & 0.98 & 0.783085 & 1.336 & 1.58 & 2.507 & 0.975 & Negativo \\
\hline 198 & verrugose & 0.95 & 0.95511 & 1.009 & 0.935 & 1.191 & 0.955 & Negativo \\
\hline 199 & verrugose & 1.11 & 0.055243 & 1.421 & 17.451 & 2.975 & 1.201 & Negativo \\
\hline 200 & verrugose & 0.95 & 0.634518 & 0.774 & 1.227 & 0.667 & 0.92 & Negativo \\
\hline 201 & verrugose & 0.95 & 0.460405 & 1.057 & 2.161 & 1.44 & 0.948 & Negativo \\
\hline 202 & verrugose & 0.96 & 0.48852 & 1.312 & 2.725 & 1.978 & 0.966 & Negativo \\
\hline 203 & verrugose & 1.13 & 0.372995 & 0.959 & 1.638 & 1.033 & 1.296 & Negativo \\
\hline 204 & verrugose & 1.28 & 0.021825 & 0.823 & 3.407 & 0.792 & 1.909 & Negativo \\
\hline 205 & verrugose & 1.06 & 0.694444 & 0.888 & 1.225 & 0.91 & 1.112 & Negativo \\
\hline 206 & verrugose & 1.19 & 0.014548 & 0.683 & 3.387 & 0.572 & 1.626 & Negativo \\
\hline 207 & verrugose & 1.18 & 0.303951 & 0.907 & 1.787 & 0.857 & 1.346 & Negativo \\
\hline 208 & verrugose & 0.83 & 1.733102 & 1.367 & 0.795 & 2.011 & 0.758 & Negativo \\
\hline 209 & verrugose & 0.91 & 0.009815 & 1.274 & 2.935 & 1.916 & 0.779 & Negativo \\
\hline 210 & verrugose & 0.88 & 1.497006 & 1.557 & 0.835 & 2.811 & 0.836 & Negativo \\
\hline 211 & verrugose & 0.80 & 0.931099 & 0.684 & 0.68 & 0.595 & 0.726 & Negativo \\
\hline 212 & verrugose & 0.77 & 0.859845 & 0.893 & 1.044 & 0.968 & 0.671 & Negativo \\
\hline 213 & verrugose & 0.79 & 1.213592 & 1.084 & 0.915 & 1.219 & 0.697 & Negativo \\
\hline 214 & verrugose & 1.33 & 0.445236 & 0.941 & 2.073 & 0.72 & 1.593 & Negativo \\
\hline 215 & verrugose & 1.25 & 0.372578 & 0.841 & 2.02 & 0.566 & 1.604 & Negativo \\
\hline 216 & verrugose & 1.05 & 0.516529 & 1.114 & 1.876 & 1.251 & 1.123 & Negativo \\
\hline 217 & verrugose & 0.94 & 0.007372 & 0.836 & 2.492 & 0.885 & 0.87 & Negativo \\
\hline 218 & verrugose & 0.87 & 0.819672 & 0.99 & 1.178 & 1.155 & 0.817 & Negativo \\
\hline 219 & verrugose & 0.90 & 0.83612 & 0.851 & 0.971 & 0.806 & 0.857 & Negativo \\
\hline 220 & verrugose & 0.88 & 1.154734 & 1.149 & 0.951 & 1.39 & 0.834 & Negativo \\
\hline 221 & verrugose & 1.01 & 0.848896 & 0.84 & 0.965 & 0.645 & 1.025 & Negativo \\
\hline 222 & verrugose & 1.02 & 0.835422 & 0.854 & 0.997 & 0.589 & 1.057 & Negativo \\
\hline 223 & verrugose & 1.08 & 0.808407 & 0.989 & 1.107 & 0.84 & 1.17 & Negativo \\
\hline 224 & verrugose & 1.31 & 0.147449 & 1.039 & 5.836 & 1.138 & 1.598 & Negativo \\
\hline 225 & verrugose & 1.16 & 0.593824 & 0.793 & 0.98 & 0.797 & 1.298 & Negativo \\
\hline 226 & verrugose & 0.98 & 2.777778 & 0.854 & 0.301 & 0.756 & 1.011 & Negativo \\
\hline 227 & verrugose & 1.04 & 1.582278 & 0.92 & 0.541 & 0.838 & 1.103 & Negativo \\
\hline 128 & greening & 1.31 & 0.654022 & 0.678 & 1.192 & 0.38 & 1.446 & Negativo \\
\hline 129 & greening & 1.62 & 0.099384 & 0.34 & 3.015 & 0.099 & 2.198 & Negativo \\
\hline 130 & greening & 1.36 & 0.195771 & 0.476 & 1.718 & 0.2 & 1.568 & Negativo \\
\hline 131 & greening & 1.62 & 0.347826 & 0.788 & 2.178 & 0.636 & 2.106 & Negativo \\
\hline 138 & greening & 1.97 & 0.364166 & 0.242 & 3.777 & 0.061 & 2.997 & Negativo \\
\hline 139 & greening & 1.81 & 0.397141 & 0.24 & 2.638 & 0.12 & 2.534 & Negativo \\
\hline 140 & greening & 1.44 & 0.035239 & 1.558 & 5.42 & 9.111 & 1.728 & Negativo \\
\hline 141 & greening & 1.63 & 0.019622 & 0.226 & 2.296 & 0.17 & 1.996 & Negativo \\
\hline 142 & greening & 1.54 & 0.011439 & 0.612 & 2.529 & 2.636 & 1.439 & Negativo \\
\hline 143 & greening & 1.57 & 0.086259 & 0.75 & 6.306 & 1.314 & 2.031 & Negativo \\
\hline 144 & greening & 1.21 & 0.358038 & 1.505 & 3.642 & 2.368 & 1.358 & Negativo \\
\hline 165 & greening & 1.82 & 0.139645 & 4.304 & 11.218 & 23.05 & 2.681 & Negativo \\
\hline 166 & greening & 2.10 & 0.051483 & 1.134 & 15.69 & 1.61 & 2.99 & Negativo \\
\hline 167 & greening & 1.86 & 0.052217 & 0.846 & 8.615 & 0.781 & 2.756 & Negativo \\
\hline 168 & greening & 1.69 & 0.0809 & 1.033 & 8.249 & 1.126 & 2.421 & Negativo \\
\hline 169 & greening & 1.59 & 0.041592 & 0.576 & 11.416 & 0.394 & 1.951 & Negativo \\
\hline 170 & greening & 1.72 & 0.002906 & 0.706 & 29.046 & 0.604 & 2.056 & Negativo \\
\hline
\end{tabular}

Continua 
Continuação

\begin{tabular}{|c|c|c|c|c|c|c|c|c|}
\hline 171 & greening & 1.46 & 0.069531 & 0.32 & 3.845 & 0.121 & 1.818 & Negativo \\
\hline 172 & greening & 1.46 & 0.002318 & 0.378 & 8.647 & 0.183 & 1.785 & Negativo \\
\hline 173 & greening & 1.47 & 0.092387 & 0.565 & 5.076 & 0.35 & 1.691 & Negativo \\
\hline 174 & greening & 1.90 & 0.064616 & 0.972 & 7.205 & 0.877 & 2.596 & Negativo \\
\hline 175 & greening & 1.78 & 0.108755 & 1.19 & 6.778 & 1.037 & 2.377 & Negativo \\
\hline 176 & greening & 1.66 & 0.154392 & 1.215 & 4.217 & 1.12 & 2.205 & Negativo \\
\hline 177 & greening & 1.57 & 0.202184 & 1.133 & 3.782 & 0.991 & 1.959 & Negativo \\
\hline 179 & greening & 1.50 & 0.474383 & 0.509 & 1.042 & 0.179 & 1.838 & Negativo \\
\hline 181 & greening & 1.47 & 0.507099 & 0.844 & 1.494 & 0.921 & 1.892 & Negativo \\
\hline 133 & cvc & 2.13 & 0.139237 & 0.913 & 5.75 & 0.909 & 3.137 & Negativo \\
\hline 134 & cve & 1.96 & 3.436426 & 0.383 & 4.513 & 0.236 & 3.017 & Negativo \\
\hline 135 & cve & 2.18 & 0.066984 & 0.38 & 4.064 & 0.196 & 3.238 & Negativo \\
\hline 136 & cve & 1.88 & 0.062116 & 0.506 & 6.93 & 0.435 & 2.601 & Negativo \\
\hline 137 & cve & 1.95 & 2.304147 & 1.963 & 2.803 & 2.19 & 2.401 & Negativo \\
\hline 145 & cve & 3.01 & 0.015866 & 0.532 & 25.267 & 0.266 & 5.041 & Negativo \\
\hline 146 & cve & 2.03 & 9.345794 & 0.95 & 0.89 & 0.692 & 3.516 & Negativo \\
\hline 147 & cve & 2.52 & 0.077839 & 0.484 & 4.589 & 0.252 & 4.094 & Negativo \\
\hline 148 & cve & 2.15 & 0.019805 & 0.277 & 11.067 & 0.082 & 3.391 & Negativo \\
\hline 149 & cve & 2.18 & 0.02448 & 0.563 & 9.699 & 0.536 & 3.281 & Negativo \\
\hline 150 & cve & 2.60 & 2.518892 & 0.775 & 11.028 & 1.358 & 3.747 & Negativo \\
\hline 151 & cve & 2.29 & 0.04754 & 0.303 & 4.325 & 0.107 & 3.375 & Negativo \\
\hline 152 & cvc & 1.74 & 0.056411 & 0.502 & 6.675 & 0.218 & 2.338 & Negativo \\
\hline 153 & cvc & 1.72 & 0.27894 & 0.758 & 2.705 & 0.713 & 2.355 & Negativo \\
\hline 154 & cvc & 2.11 & 0.133404 & 0.707 & 4.92 & 0.57 & 3.055 & Negativo \\
\hline 155 & cve & 1.64 & 0.182682 & 0.788 & 2.884 & 0.905 & 2.119 & Negativo \\
\hline 156 & cvc & 1.92 & 0.150921 & 0.459 & 3.197 & 0.196 & 2.57 & Negativo \\
\hline 157 & cve & 1.93 & 0.534759 & 1.601 & 2.977 & 0.965 & 2.683 & Negativo \\
\hline 158 & cve & 2.32 & 0.006149 & 1.176 & 27.126 & 0.316 & 2.933 & Negativo \\
\hline 159 & cve & 1.63 & 0.049237 & 0.428 & 11.988 & 0.079 & 2.125 & Negativo \\
\hline 160 & cve & 1.84 & 0.074256 & 0.934 & 5.519 & 1.263 & 2.585 & Negativo \\
\hline 161 & cve & 1.82 & 0.059242 & 0.986 & 12.031 & 0.864 & 2.467 & Negativo \\
\hline 162 & cve & 1.90 & 0.027782 & 0.405 & 4.729 & 0.297 & 2.895 & Negativo \\
\hline 163 & cve & 1.91 & 0.045625 & 2.582 & 7.433 & 2.322 & 2.674 & Negativo \\
\hline 164 & cve & 1.64 & 0.50025 & 1.109 & 3.212 & 0.259 & 2.011 & Negativo \\
\hline 178 & cvc & 2.15 & 0.325839 & 0.682 & 1.636 & 0.578 & 3.085 & Negativo \\
\hline 182 & cvc & 2.11 & 0.258264 & 0.423 & 1.352 & 0.185 & 3.191 & Negativo \\
\hline
\end{tabular}

Conclusão 


\title{
ANEXO A - PUBLICAÇÕES EM PERIÓdICOS REFERENTES AO TRABALHO DESENVOLVIDO.
}

\section{Fluorescence Spectroscopy Applied to Orange Trees}

\author{
L. G. Marcassa ${ }^{a}$, M. C. G. Gasparoto ${ }^{b}$, J. Belasque Junior ${ }^{b}$, E. C. Lins ${ }^{c}$, \\ F. Dias Nunes ${ }^{c}$, and V.S. Bagnato ${ }^{a}$ \\ ${ }^{a}$ IFSC-Universidade de São Paulo, São Carlos, São Paulo, 135665-90, Brazil \\ ${ }^{b}$ Departamento Cientifico-FUNDECITRUS, Araraquara, São Paulo, $201148070-40$, Brazil \\ ${ }^{c}$ DES-Universidade Federal de Pernambuco, Recife, Pernambuco, 50670-901, Brazil \\ e-mail: lgmarcassa@uol.com.br \\ Received December 26, 2005
}

\begin{abstract}
In this work, we have applied laser-induced fluorescence spectroscopy to investigate biological processes in orange trees (Citrus aurantium L.). We have chosen to investigate water stress and Citrus Canker, which is a disease caused by the Xanthomonas axonopodis pv. citri bacteria. The fluorescence spectroscopy was investigated by using as an excitation source a 442-nm 15- $\mathrm{mW}$ HeCd gas multimode discharge laser and a 532$\mathrm{nm} 10-\mathrm{mW} \mathrm{Nd}^{3+}$ :YAG laser. The stress manifestation was detected by the variation of fluorescence ratios of the leaves at different wavelengths. The fluorescence ratios present a significant variation, showing the possibility to observe water stress by fluorescence spectrum. The Citrus Canker's contaminated leaves were discriminated from the healthy leaves using a more complex analysis of the fluorescence spectra. However, we were unable to discriminate it from another disease, and new fluorescence experiments are planned for the future.
\end{abstract}

PACS numbers: 07.60.RD, 07.57.TY, 82.50.-M

DOI: $10.1134 / \mathrm{S} 1054660 \mathrm{X} 06050215$ 


\title{
Detection of citrus canker in citrus plants using laser induced fluorescence spectroscopy
}

\author{
Emery C. Lins · José Belasque Jr. · Luis G. Marcassa
}

Published online: 17 June 2009

(1) Springer Science+Business Media, LLC 2009

\begin{abstract}
Citrus canker is a serious disease caused by Xanthomonas citri subsp. citri bacteria, which infects citrus plants (Citrus spp.) leading to a large economic loss in citrus production worldwide. In Brazil citrus canker control is done by an official eradication campaign, therefore early detection of such disease is important to prevent greater economic losses. However, detection is difficult and so far it has been done by visual inspection of each tree. Suspicious leaves from citrus plants in the field are sent to the laboratory to confirm the infection by laboratory analysis, which is a time consuming. Our goal was to develop a new optical technique to detect and diagnose citrus canker in citrus plants with a portable field spectrometer unit. In this paper, we review two experiments on laser induced fluorescence spectroscopy (LIF) applied to detect citrus canker. We also present new data to show that the length of time a leaf has been detached is an important variable in our studies. Our results show that LIF has the potential to be applied to citrus plants.
\end{abstract}

Keywords Citrus canker - Fluorescence spectroscopy $\cdot$ Diagnosis - Laser 


\section{Revista Brasileira de \\ Engenharia Biomédica}

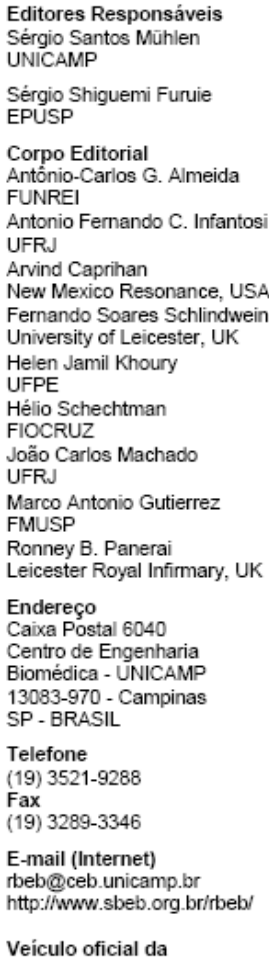

Campinas, 24 de julho de 2009

\section{Ilmos. Srs. Emery Cleiton Cabral Correia Lins, Luis Gustavo} Marcassa.

\section{Ref. Artigo: "Construção e Caracterização de um Sistema de Imagens} Hiperespectrais".

Trabalho $\mathrm{n}^{\circ} \mathbf{2 0 0 8 - 2 0}$ v.2

Prezados autores,

Temos a satisfação de informar que o original acima foi analisado pelo Corpo de Revisores da RBEB, tendo sido aceito para publicação.

A editoração do artigo será efetuada a partir da última versão fornecida por V.Sas., visando sua adequação ao formato da revista. Na eventualidade de qualquer problema na preparação da versão final, V.Sas. poderão vir a ser contatadas diretamente pelo responsável pela editoração. Tão logo o artigo seja impresso, estaremos enviando as separatas.

Muitíssimo gratos por sua valiosa contribuição, ficamos à disposição para novas submissões.
Atenciosamente,

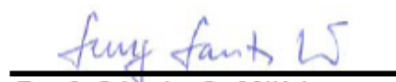

Prof. Sérgio S. Mühlen

Editor Responsável

rbeb@ceb.unicamp.br 